\author{
UNIVERSIDADE DE SÃO PAULO \\ FACULDADE DE ECONOMIA, ADMINISTRAÇÃO E CONTABILIDADE \\ DEPARTAMENTO DE ECONOMIA \\ PROGRAMA DE PÓS-GRADUAÇÃO EM ECONOMIA
}

\title{
ESSAYS ON ENVIRONMENTAL POLICY EVALUATION
}

Ensaios em Avaliação de Políticas Ambientais

Maria Alice Móz Christofoletti

Orientador: Prof. Dr. Paula Carvalho Pereda

São Paulo - Brasil

2020 

Prof. Dr. Vahan Agopyan

Reitor da Universidade de São Paulo

Prof. Dr. Fabio Frezatti

Diretor da Faculdade de Economia, Administração e Contabilidade

Prof. Dr. Jose Carlos de Souza Santos

Chefe do Departamento de Economia

Prof. Dr. Ariaster Baumgratz Chimeli

Coordenador do Programa de Pós-Graduação em Economia 



\section{MARIA ALICE MOZ CHRISTOFOLETTI}

Tese apresentada ao Departamento de Economia da Faculdade de Economia, Administração e Contabilidade da Universidade de São Paulo como requisito parcial para a obtenção do título de Doutor em Ciências.

Área de concentração: Economia do Desenvolvimento

Orientador: Prof. Dr. Paula Carvalho Pereda

Versão Corrigida

São Paulo - Brasil

2020 
Moz Christofoletti, Maria Alice.

ESSAYS IN ENVIRONMENTAL POLICY EVALUATION / Maria Alice

Moz Christofoletti. - São Paulo, 2020. $159 \mathrm{p}$.

Tese (Doutorado) - Universidade de São Paulo, 2020.

Orientador: Paula Carvalho Pereda.

1. CO2e emissions. 2. Carbon taxation. 3. Policy Evaluation. 4. Censored QUAIDS. 5. Regression Discontinuity Design. I. Universidade de São Paulo. Faculdade de Economia, Administração e Contabilidade. II. Título. 
To my grandmother Irma (in memoriam). 



\section{ACKNOWLEDGMENTS}

This journey would not have been possible without the support of my family, professors and friends. I would like to thank my family, specially my parents Isabel and Inacio, for their unconditional love and for understanding the absence that long projects sometimes impose.

I am grateful to my advisor, Paula Carvalho Pereda, whose patience and support have accompanied me since day one. You have given me the freedom to pursue various personal and professional projects without objection.

To Professors Ariaster Chimeli and Naércio Menezes Filho, members of my PhD committee, for their valuable and insightful comments in all my progress' asssement presentations, which significantly enriched the final work. To Pinho and Leka, for their amazing assistance, specially after my departure to Italy. I also thank CAPES for the financial support during the first years of the $\mathrm{PhD}$ programme.

To my dearest friends, Veridiana, Luana and Anne, who became my roman family, and FAO (Office of Evaluation) colleagues, who made possible the hard task to partly combine $\mathrm{PhD}$ and a full-time job. Also to my JRC colleagues, for their understanding and support on the final stage of this thesis, and to Wesley Campanharo (INPE), for the fruitful discussions and feedbacks to Chapter 3.

To my beloved friends, Carolina and Patrícia, for their valuable comments on this thesis and for always being there.

My special gratitude to Rodolfo, my husband, for the love and respect. You have given me the extra strength and motivation to get things done. 

Ho avuto tutte le notti per moltiplicare I sogni Sistemare I miei pensieri $\mathrm{E}$ archiviare I ricordi dei giorni perfetti E come nei film c'è una scena finale Dove vado di fretta, la mia vita mi aspetta 



\section{ABSTRACT}

This thesis examines three topics related to current and potential policies to reduce greenhouse gases emission (GHG) emissions in Brazil.

The first chapter, entitled "Distributional Welfare and Emission Effects of Energy Tax Policies in Brazil" calculates carbon intensity of 128 products consumed by Brazilian households and utilizes a rich household dataset to investigate the short-run impacts of energy policies in Brazil in the 2000s. Results indicate that $11 \%$ of total additional energy emissions between 2010 and 2018 (or 6.5 MtCO2e) could have been avoided in the absence of government tax reductions on diesel, electricity and residential appliances and increments on gasoline taxes. Findings also suggest that taxes on gasoline pump prices are progressive and have a negative impact on total household energy emissions due to substitution effects. Changes in electricity prices are regressive and have large effects on household emissions. More environmentally friendly policies, such as subsidy on ethanol, are the most cost-effective to reduce emissions, despite its small effect on the emissions of the economy. Understanding who benefits from energy taxes and subsidies is key to gaining public support for a greener energy mix, as pledged by the country in its NDC.

The second chapter, entitled "Winners and Losers: The Distributional Impacts of a Carbon Tax in Brazil" continues to investigate how economy-wide policy alternative instruments, such as a carbon tax, influence the emissions and welfare of Brazilians and the opportunities to implement such instruments in a tax reform context. Estimates suggest that it is possible to observe the first dividend in the Brazilian context, as it could reduce annual GHG emissions by up to $4.2 \%$. However, since low-income households are less price-responsive for the majority of carbon intensive categories, they suffer a larger relative welfare loss due to the carbon tax $(0.10 \%$ of their total expenditures, vis-à-vis $0.06 \%$ for richest households). They are also more likely to suffer from a larger relative indirect effect of "food and beverages" and "housing-related" consumption, which accounts for a greater budget share of these households. Significant changes in total GHG would require a higher tax rate, which would reinforce the regressiveness of the policy. These results indicate that compensation strategies, such a direct lump-sum transfer, need to be considered by the government to reduce the burden imposed on these households. Given the significant complexities in the Brazilian tax system, the generation of a second dividend effect could be observed only if the country implements carbon pricing mechanism as part of a broader structural tax reform. 
The third chapter, entitled "Does Decentralized and Voluntary Commitment Reduce Deforestation? The Effects of Programa Municípios Verdes" utilizes regression discontinuity and high-resolution spatial dataset (1,781,122 pixels covering $\left.162,242 \mathrm{~km}^{2}\right)$ to examine the effect of a Brazilian state-level programme implemented in 2011 on deforestation rates. The programme was implemented in one of the country's state that present the highest deforestation rates. Evidence suggest avoidance of roughly 8.0 $\mathrm{MtCO} 2 /$ year released to the atmosphere, and the extrapolation of estimates to the total area that could be legally deforested in Pará indicates that $41 \%$ of deforestation in the Amazon region between 2015 and 2018 could have been prevented using this voluntary initiative. Since Brazil has committed through its NDC to eliminate deforestation in the Amazon by 2030, decentralized programmers with focus on indirect benefits appear to be effective in the long-run, serving as a "bonus" to support those regions with higher levels of forest cover.

Key-words: Censored QUAIDS, Regression Discontinuity Design, Carbon taxation, $\mathrm{CO}_{2} \mathrm{e}$ emissions, Censored QUAIDS, Policy Evaluation, Deforestation, Emissions, Decentralization 


\section{RESUMO}

Esta tese explora as recentes mudanças nos padrões de emissão de gases de efeito estufa (GEE) no Brasil para fornecer evidências sobre possíveis trocas, nas políticas de impostos sobre a energia e na eficácia de iniciativas de combate ao desmatamento.

O primeiro capítulo avalia o bem-estar e as emissões e os efeitos nos diferentes níveis de renda das famílias das políticas de imposto sobre energia implementadas recentemente no Brasil. As conclusões sugerem que os impostos sobre os preços das bombas de gasolina são progressivos e têm um impacto negativo nas emissões totais de energia das famílias devido à substituição e aos efeitos. Apesar de regressivas, as mudanças nos preços da eletricidade têm grandes efeitos sobre as emissões domésticas devido às características do suprimento de energia elétrica no Brasil. Os resultados mostram que $11 \%$ do total aditional de emissões de energia entre 2010 e 2018 (ou 6,5 MtCO2e) poderia ter sido evitado na ausência de subsídios governamentais ao diesel, eletricidade e eletrodomésticos e impostos sobre a gasolina. Políticas mais amigáveis ao meio ambiente, como subsídio ao etanol, podem ter um efeito pequeno, mas positivo, na economia e tendem a reduzir as emissões domésticas. No entanto, grandes substituições e efeitos devido ao aumento da demanda por produtos intensivos em CO2e, como serviços de transporte e deslocamento - ao taxar a gasolina não definem ou reduzem a emissão causada por um preço mais baixo do etanol. Portanto, entender quem se beneficia dos impostos e subsídios à energia é fundamental para obter apoio público para um mix de energia mais verde, conforme prometido pelo país em seu NDC.

O segundo capítulo investiga os efeitos distributivos de um imposto sobre o carbono em toda a economia. As estimativas sugerem que é possível observar o primeiro dividendo no contexto brasileiro, pois isso pode reduzir as emissões anuais de GEE em até 4,2 \%. No entanto, como as famílias de baixa renda são menos responsivas aos preços para a maioria das categorias intensivas em carbono, elas sofrem uma maior perda de bem-estar relativa devido ao imposto sobre o carbono $(0,10 \%$ em relação às despesas totais, em relação a 0,06 \% para as famílias mais ricas). Eles também são mais propensos a sofrer um efeito indireto relativo maior de "alimentos e bebidas e consumo "relacionado à habitação, o que representa uma maior parcela do orçamento dessas famílias. Mudanças significativas no total de GEE exigiriam uma taxa de imposto mais alta, o que reforçaria a regressividade da política. Esses resultados indicam que as estratégias de compensação, 
como uma transferência direta e total, precisam ser consideradas pelo governo para reduzir o ônus imposto a essas famílias. Dadas as complexidades significativas no sistema tributário brasileiro, a geração de um segundo efeito de dividendo só poderia ser observada se o país implementasse o mecanismo de precificação de carbono como parte de uma reforma tributária estrutural mais ampla.

O terceiro artigo tira proveito de um programa estadual e voluntário brasileiro implementado em 2011 para avaliar sua eficácia na redução de uma das maiores taxas de desmatamento do país. Evidências sugerem evitar aproximadamente 8,0 MtCO2 / ano liberados na atmosfera, e a extrapolação de estimativas para a área total que pode ser desmatada legalmente no Pará indica que 41 \% do desmatamento na região amazônica entre 2015 e 2018 poderia ter sido evitado usando esta iniciativa voluntária. Como o Brasil se comprometeu, através de seu NDC, a eliminar o desmatamento na Amazônia até 2030, programadores descentralizados com foco em benefícios indiretos parecem ser eficazes a longo prazo, servindo como um "bônus para apoiar as regiões com níveis mais altos de cobertura florestal .

Palavras-chaves: QUAIDS Censurado, Taxação de Carbono, Emissões de $\mathrm{CO}_{2}$, Avaliação de Politicas, Desmatamento, Descentralização 


\section{LIST OF FIGURES}

Figure 1.1 - Evolution of GHG $\left(\mathrm{MtCO}_{2} \mathrm{e}\right)$ emission from energy sector (2000-2018),

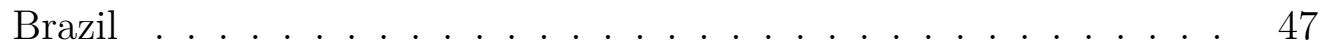

Figure 1.2 - Overview: Energy taxation policies on consumption from 1970 to 201848

Figure $2.1-\mathrm{CO}_{2} \mathrm{e}$ Emission Coefficient $\left(\mathrm{tCO}_{2} \mathrm{e} / \mathrm{USD}\right.$ million 2019) . . . . . . . . 93

Figure 3.1 - Location of the study area: Pará's borders . . . . . . . . . . . . . 127

Figure 3.2 - Annual deforestation in the Brazilian Amazon . . . . . . . . . . . . 129

Figure 3.3 - Location of study area: grid cells within $100 \mathrm{~km}$ buffer zone . . . . 130

Figure 3.4 - PMV: municipalities according to year of adherence . . . . . . . . . 131

Figure 3.5 - Maps of control variables . . . . . . . . . . . . . . . . . . . . . . . . 132

Figure 3.6 - Average annual forest cover at Pará Borders in different Brazilian states (excluding conservation units and indigenous lands) . . . . . 134

Figure 3.7 - RD Effects - \% of forest cover . . . . . . . . . . . . . . . . . 135

Figure 3.8 - Avoided $\mathrm{CO}_{2}$ emissions $\left(\mathrm{MtCO}_{2}\right)$. . . . . . . . . . . . . . . . 139

Figure 3.9 - Sensitivity to bandwidth choice (optimal, $20 \mathrm{~km}$ and $30 \mathrm{~km}$ ) . . . . 140

Figure 3.10-Location of rural settlements . . . . . . . . . . . . . . . . . . . . . . 142

Figure 3.11-Test for manipulation around the cutoff: density of the running variable147 



\section{LIST OF TABLES}

Table 1.1 - Compatibilization - SUTs and BEN . . . . . . . . . . . . . 48

Table 1.2 - Description of expenditure groups . . . . . . . . . . . . . . . . . 49

Table 1.3 - Summary statistics: socioeconomic characteristics (mean/(sd)) . . . 50

Table 1.4 - Price indices by group and income level (in USD 2019 values) (mean/(sd)) 51

Table 1.5 - Positive consumption and expenditure shares by group/ income level

(\%) $(\operatorname{mean} /(\mathrm{sd})) \ldots \ldots \ldots . \ldots . \ldots . \ldots 52$

Table 1.6 - Expenditure share of energy goods by income level (mean/(sd) . . . 52

Table 1.7 - Description of policy scenarios . . . . . . . . . . . . . . . 53

Table 1.8 - Total $\mathrm{CO}_{2} \mathrm{e}$ Emission $\left(\mathrm{tCO}_{2} \mathrm{e} / \mathrm{hh} /\right.$ year, in 2019 values $) \ldots \ldots$. . . . 53

Table $1.9-\mathrm{CO}_{2} \mathrm{e}$ emission coefficients $\left(\mathrm{tCO}_{2} \mathrm{e} / \mathrm{USD}\right.$ million, 2019) from intermediate consumption and final demand for each good/service in the economy $(2010)$. . . . . . . . . . . . . . . . . . .

Table 1.10- $\mathrm{CO}_{2} \mathrm{e}$ emission coefficients $\left(\mathrm{tCO}_{2} \mathrm{e} / \mathrm{USD}\right.$ million, 2019) from intermediate consumption and final demand for each good/service in the economy (2010) (cont.) . . . . . . . . . . . . . . . .

Table 1.11- $\mathrm{CO}_{2} \mathrm{e}$ emission coefficients $\left(\mathrm{tCO}_{2} \mathrm{e} / \mathrm{USD}\right.$ million, 2019) from intermediate consumption and final demand for each good/service in the economy (2010) (cont.) . . . . . . . . . . . . . . . . .

Table 1.12-Expenditure and price elasticities estimated using Censored QUAIDS model (beta/se): full sample, $20 \%$ poorest, and $20 \%$ richest. . . . . .

Table 1.13-Expenditure and price elasticities for energy goods estimated using Censored QUAIDS model (beta/se): full sample, $20 \%$ poorest, and $20 \%$ richest.

Table 1.14-Marshallian $\left(\epsilon_{i j}\right)$ price elasticities using Censored QUAIDS, full sample $($ mean $/(\mathrm{sd}))$

Table 1.15-Hicksian $\left(\epsilon_{i j}^{H}\right)$ price elasticities using Censored QUAIDS, full sample $(\operatorname{mean} /(\mathrm{sd}))$

Table 1.16-Simulation results for full sample, $20 \%$ poorest, and $20 \%$ richest. . . 61

Table 2.1 - Description of expenditure groups . . . . . . . . . . . . . . . 94

Table 2.2 - Positive consumption and budget shares by group/ income level (\%) $($ mean $/ \mathrm{sd}) \ldots \ldots \ldots \ldots 5$

Table 2.3 - Summary statistics: socioeconomic characteristics (mean/(sd)) . . 96

Table 2.4 - Price Indices by group and income level (in USD 2019 values) (Mean/(sd)) 97

Table 2.5 - Total $\mathrm{CO}_{2} \mathrm{e}$ emission $\left(\mathrm{tCO}_{2} \mathrm{e} / \mathrm{hh} /\right.$ year, in 2019 values $) \ldots \ldots 7$ 
Table 2.6 - Expenditure and price elasticities estimated using censored QUAIDS model (mean/(sd)): full sample, $20 \%$ poorest, and $20 \%$ richest. . . .

Table 2.7 - Marshallian $\left(\epsilon_{i j}\right)$ price elasticities using censored QUAIDS, full sample $($ mean $/(\mathrm{sd})) \ldots \ldots \ldots \ldots \ldots \ldots$

Table 2.8 - Hicksian $\left(\epsilon_{i j}^{H}\right)$ price elasticities using censored QUAIDS, full sample

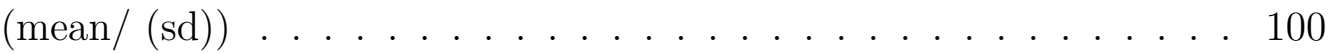

Table 2.9 - Distributional welfare and emission effects of a USD $40 / \mathrm{tCO}_{2} \mathrm{e}$ and USD 80/ $\mathrm{tCO}_{2} \mathrm{e}$ carbon tax in Brazil (USD 2019 values) . . . . . . . 101

Table 2.10-Distributional welfare and emission effects of a USD 40/ $\mathrm{tCO}_{2} \mathrm{e}$ and USD $80 / \mathrm{tCO}_{2} \mathrm{e}$ carbon tax levied on commuting and transportation services (USD 2019 values) . . . . . . . . . . . . . 102

Table 2.11-Distributional welfare and emission effects of a USD $40 / \mathrm{tCO}_{2} \mathrm{e}$ and USD 80/ $\mathrm{tCO}_{2}$ e carbon tax levied on food and beverages (USD 2019 values $\ldots \ldots \ldots$. . . . . . . . . . . . . . . . . . 103

Table 3.1 - List of Pará municipalities that are part of the PMV . . . . . . . . . 128

Table 3.2 -Summary Statistics . . . . . . . . . . . . . . . . . . . . 133

Table 3.3 - RD estimator effect on $\%$ of forest cover $(\delta) \ldots \ldots . \ldots . . \ldots 137$

Table 3.4 - RD estimator effect on \% of forest cover $(\delta)$ excluding MMA's priority list municipalities . . . . . . . . . . . . . . . . . . . 138

Table 3.5 - RD estimator effect (\% of forest cover) excluding rural settlements . 141

Table 3.6 - List of Full Protection Conservation Units . . . . . . . . . . . . . . . 141

Table 3.7 - Placebo outcomes - RD estimator effect (\% of forest cover) on Full Protection Units . . . . . . . . . . . . . . . . . . . . . . . 143

Table 3.8 - Treatment effect (\% of forest cover) accounting for unobservable heterogeneity . . . . . . . . . . . . . . . . . . . 144

Table 3.9 - Validation test - predetermined controls . . . . . . . . . . . . . 145 


\section{TABLE OF CONTENTS}

Page

LIST OF FIGURES . . . . . . . . . . . . . . . . . . . . . . . . . . . . . . . . 15

LIST OF TABLES . . . . . . . . . . . . . . . . . . . . . . . . . . . . 18

1 DISTRIBUTIONAL WELFARE AND EMISSION EFFECTS OF ENERGY

TAX POLICIES IN BRAZIL . . . . . . . . . . . . . . . . . . . . . . . . 21

1.1 Introduction . . . . . . . . . . . . . . . . . . . 21

1.2 Background: energy taxation on consumption . . . . . . . . . . 24

1.3 Empirical Strategy and Data . . . . . . . . . . . . . . . 28

1.3.1 $\mathrm{CO}_{2} \mathrm{e}$ emission coefficients . . . . . . . . . . . 28

1.3.1.1 Data...................... 29

1.3.2 Household elasticities: Censored QUAIDS . . . . . . . . . . 30

1.3.2.1 Data . . . . . . . . . . . . . 32

1.3.2.2 Construction of price aggregates . . . . . . . . . 32

1.3.3 Policy simulation . . . . . . . . . . . . . . . . . 34

1.3.3.1 Scenarios ................... . . 34

1.3.3.2 Welfare effects . . . . . . . . . . . . 35

1.3.3.3 Emission effects . . . . . . . . . . . . . . 36

1.4 Results . . . . . . . . . . . . . . . . . 36

1.4.1 $\mathrm{CO}_{2} \mathrm{e}$ emission coefficients . . . . . . . . . . . 36

1.4.2 Price and expenditure elasticities . . . . . . . . . . . . . 38

1.4.3 Tax simulations: Welfare and emissions effects . . . . . . . . . . 40

1.5 Conclusions . . . . . . . . . . . . . . . . . . . . . . . 43

A Tables and Figures . . . . . . . . . . . . . . . 47

B Appendix B - Price correction of censored QUAIDS . . . . . . . . 62

2 WINNERS AND LOSERS: THE DISTRIBUTIONAL IMPACTS OF A CARBON TAX IN BRAZIL . . . . . . . . . . . . . . . . 63

2.1 Introduction . . . . . . . . . . . . . . . . . . 63

2.2 Literature Review . . . . . . . . . . . . . . . . . . . 66

2.3 Empirical Strategy and Data . . . . . . . . . . . . . . . 72

2.3.1 Emission coefficients: input-output model . . . . . . . . . . . 73

2.3.2 Households' responses to prices: censored QUAIDS . . . . . . . 75

2.3.2.1 Construction of prices . . . . . . . . . . . 80

2.3.3 Calculation of effects . . . . . . . . . . . . . . . 81

2.3.3.1 Welfare effects . . . . . . . . . . . . . 81 
2.3.3.2 Emissions effects . . . . . . . . . . . . . 82

2.3.3.3 Neutral revenue . . . . . . . . . . . . . . . . 83

2.3.4 Scenarios and sensitivity analysis . . . . . . . . . . . . 83

2.4 Results and Discussions . . . . . . . . . . . . . . . . . . . . . . . 84

2.4.1 $\mathrm{CO}_{2} \mathrm{e}$ emission coefficients ................. 84

2.4.2 Expenditure, own- and cross- price elasticities . . . . . . . . 85

2.4.3 Welfare and emissions effects . . . . . . . . . . . . . 88

2.4.4 Sensitivity analysis . . . . . . . . . . . . . . . . . 89

2.5 Conclusions and Policy Implications . . . . . . . . . . . . . . . . . . 90

A Tables and Figures . . . . . . . . . . . . . . . . . . . 93

3 DOES DECENTRALIZED AND VOLUNTARY COMMITMENT REDUCE DEFORESTATION? THE EFFECTS OF PROGRAMA MUNICÍPIOS

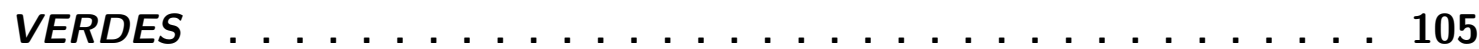

3.1 Introduction . . . . . . . . . . . . . . . . . . . 105

3.2 The Green Municipalities Program (PMV) . . . . . . . . . . . . . . . . 108

3.3 Empirical methods and data . . . . . . . . . . . . . . . . . . 113

3.3.1 Empirical strategy . . . . . . . . . . . . . . . . . 113

3.3.2 Spatial data construction . . . . . . . . . . . . . . . . 115

3.3.2.1 Spatial data . . . . . . . . . . . . . . 115

3.3.2.2 Dataset generation . . . . . . . . . . . 116

3.3.3 Conversion of biomass into $\mathrm{CO}_{2} \ldots \ldots \ldots 117$

3.4 Results and discussion . . . . . . . . . . . . . . . . . . . 117

3.4.1 Deforestation . . . . . . . . . . . . . . 117

3.4.2 Avoided $\mathrm{CO}_{2}$ emissions . . . . . . . . . . . . . . . . 121

3.5 Robustness tests . . . . . . . . . . . . . . . . . . . 121

3.5.1 Sensitivity to bandwidth choice . . . . . . . . . . . . . 121

3.5.2 Sensitivity to other programmes - Bolsa Verde . . . . . . . . . . 122

3.5.3 Placebo test: full protection conservation units . . . . . . . . . . 123

3.5.4 Accounting for unobservable heterogeneity . . . . . . . . . . . . 123

3.6 Conclusions and policy implications . . . . . . . . . . . . . . . . 125

A Tables and Figures . . . . . . . . . . . . . . . . . . 127

B Validation tests . . . . . . . . . . . . . . . . . . . 145

B.1 Predetermined controls . . . . . . . . . . . . . . . . 145

B.2 Manipulation around the cutoff . . . . . . . . . . . . . . 145

REFERENCES . . . . . . . . . . . . . . . . . . . . . 149 


\section{Chapter 1}

\section{DISTRIBUTIONAL WELFARE AND EMISSION EFFECTS OF ENERGY TAX POLICIES IN BRAZIL}

\subsection{Introduction}

Energy-related GHG emissions have increased sharply in Brazil, from 290 million tonnes of carbon dioxide equivalent $\left(\mathrm{MtCO}_{2} \mathrm{e}\right)$ in 2000 to $407.4 \mathrm{MtCO}_{2} \mathrm{e}$ in $2018^{1.2}$. Against international commitments to reduce emissions ${ }^{1.3}$, Brazilian policies artificially reduced end consumer prices for fossil fuels and electricity to curb inflation resulting in total subsidies of USD 4.9 billion in $2015^{1.4}$. Artificial relative prices have equity effects as they affect household purchasing power and shift expenditure across goods and services (Pizer and Sexton, 2017). The literature still lacks empirical evidence regarding the cost-effectiveness of such policies, especially with regard to the distributional effects (effects across different incomes) considering potential substitution and complementarity among goods.

To shed light on the discussion of distributional effects and cost-effectiveness of energy tax policies, we assess their short-term impacts on GHG emission and welfare for different household income levels in Brazil. We use rich household budget microdata and match them with energy requirement data to calculate the carbon footprint for all products. We use both de facto tax cuts and increases in tax rates implemented on

\footnotetext{
${ }^{1.1}$ We are grateful to the participants of the European Association of Environmental and Resource Economists and the European Economic Association congresses for their valuable comments.

${ }^{1.2}$ Brazilian energy emissions increased $2 \%$ per year, while total emissions decreased $1 \%$ per year in the period, to $21.4 \%$ of Brazilian emissions in 2018 (data from the Greenhouse Gas Emissions Estimation System (SEEG) of the Climate Observatory Initiative). See Appendix Figure 1.1.

${ }^{1.3}$ In Brazil, the Nationally Determined Contribution Towards Achieving the Objective of the United Nations Framework Convention on Climate Change (NDC-Br 2015), in which Brazil pledged by 2030 to: i) increase the share of sustainable biofuels in the energy mix to approximately $18 \%$; ii) achieve $45 \%$ of renewables in the energy mix; iii) expand the use of renewables other than hydropower in the total energy mix to between $28 \%$ to $33 \%$; iv) increase the share of renewables other than hydropower in electricity supply to at least $23 \%$ and v) achieve $10 \%$ efficiency gains in the electricity sector.

${ }^{1.4}$ Brazil's subsidies to fossil fuels cover mostly oil and gas production and supply, and include research and development investments, drilling and fuel transport, as well as power generation (Bast et al., 2015).
} 
different energy goods (transport fuels, electricity and gas, and residential appliances). We also simulate alternative and more environmentally friendly tax policies which, in theory, tend to reduce GHG emissions. The essential idea behind the distributional effects that we calculate is that taxing a good that is used mainly by the rich is progressive, while taxing a good used predominantly by the poor is regressive (Sterner, 2012).

The period we analyze is the late 2000s. During this period, the Brazilian government granted tax exemptions on fossil fuels to reduce the rate of inflation due to the rising price of oil, a result of the 2008 economic crisis. The reduction in fossil fuel prices encouraged individuals to choose the fossil fuel option over ethanol (enabled by flex-fuel vehicles ${ }^{1.5}$ ), which had serious consequences for the ethanol industry. Later on, in an attempt to boost economic growth, the Brazilian government prioritized policies aimed at increasing electricity consumption. Furthermore, changes in the weather reduced the amount of electricity generated by hydropower and increased the share of thermal power fueled by natural gas, biomass and coal in the Brazilian electricity matrix.

To analyze the institutional setting, our estimation strategy comprises three steps. First, we calculate the direct and indirect carbon dioxide equivalent $\left(\mathrm{CO}_{2} \mathrm{e}\right)$ emission coefficient from the burning of fossil fuels (carbon footprint) for 128 household products. To do this, we use energy requirement data and the national input-output matrix to generate the carbon footprint by product. Second, we estimate the price and expenditure elasticities derived from a censored demand system for the total household consumption basket. We apply price corrections and use instrumental variables to estimate demand elasticities. We also estimate different elasticities by income group (poor households are below percentile 20 of total income and rich households are above percentile 80 of total income). Finally, using the estimated carbon footprint and price elasticities, we calculate the effects of end consumer price changes on household consumption, emissions and welfare across income-level groups. The price changes assessed are not only de facto tax and subsidy rates implemented on end consumer prices in the 2000s, but also alternative and more environmentally friendly tax policies.

Our findings suggest that the short-term emission and welfare effects at the household level can be substantial, depending on the policy. Tax and subsidies on gasoline are progressive and have negative impacts on total household energy emissions

\footnotetext{
${ }^{1.5}$ In Brazil, flex-fuel vehicles are ethanol- and gasoline-powered cars that are produced by the auto industry in Brazil since 2003. See more details in Section 1.2.
} 
due to substitution effects. Despite being regressive, changes in electricity prices have considerable effects on household emissions due to the characteristics of the electricity supply in Brazil. We estimate that at least $11 \%$ of total additional energy emissions between 2010 and 2018 (or $6.5 \mathrm{MtCO}_{2} \mathrm{e}$ ) could have been avoided with the absence of these tax increases. Alternative policies that subsidize ethanol have a small but positive effect on the economy and tend to reduce household emissions. However, when combining subsidies for ethanol and additional taxes on gasoline and diesel, we observe large substitution effects due to an increase in the demand for other $\mathrm{CO}_{2} \mathrm{e}$-intensive goods. These include commuting and transportation services, which are more than sufficient to offset emissions reduction caused by a lower ethanol price. Policies that promote more efficient use of electricity tend to be regressive and also increase household carbon footprints. Overall, we find that subsidies on ethanol are 34 times more costeffective than subsidies on electricity and gas, but they have a lower capacity to reduce emissions than the latter.

Our contribution to the literature is threefold. First, we contribute to the empirical literature that explores general distributional effects of energy (transportation fuels and electricity) tax policies for developing countries. For transport fuel taxes, many papers indicate that, while there may be slight regressivity in some high-income countries, fuel taxation (either direct or as a carbon tax) is progressive particularly in low- and middle-income countries, where it can be considered a 'luxury tax'1.6 (Granado et al., 2012; Nikodinoska and Schröder, 2016; Feng et al., 2018; Pizer and Sexton, 2017). Evidence suggests that fuel subsidies might be a costly approach to protecting the poor due to substantial benefit leakage to higher income groups (Sterner, 2012) ${ }^{1.7}$. Nonetheless, a transport fuel price increase/tax could lead to greater emission reductions, driven by relatively large budget shares and high carbon intensity (Renner et al., 2018; Renner et al., 2017).

With regard to the impact of changes in electricity prices, evidence suggests that in developing countries, where electrification rates are relatively low, or where

\footnotetext{
${ }^{1.6}$ 'Luxury tax' are ad valorem taxes or progressive taxes charged on high-priced goods deemed non-essential.

${ }^{1.7}$ These differences appear to be due to differences in car usage by income groups and availability of public transport: in developing countries, poorer households may be less likely to own a car or use taxis and personal driving services, and therefore spend a very small share of their money on fuel for transport. In India, for example, transport fuel expenditure amounts to less than $2 \%$ of total income for the lowest income decile and $8 \%$ of total income for the wealthiest income decile (Morris and Sterner, 2013). However, lack of public transport may lead to regressive effects of taxes on transport fuels (Flues and Thomas, 2015; Wang et al., 2016).
} 
energy-consuming durable goods are beyond the reach of poor households, electricity taxes tend to be progressive (Flues and Thomas, 2015; Pizer and Sexton, 2017; Cottrell and Falcão, 2018). However, as income grows, and households become more connected to the grid, electricity taxes are likely to have a higher impact on middle- and low-income households (Flues and Thomas, 2015; Feng et al., 2018; Pizer and Sexton, 2017) ${ }^{1.8}$.

Second, we also contribute to the literature as we analyze the cost-effectiveness of different policies in terms of both welfare costs and $\mathrm{CO}_{2}$ e emissions in Brazil. Most studies have assessed only one channel of the effects of energy taxes and subsidies, in monetary terms, by measuring the changes of expenditures as tax burdens and variations in welfare (Flues and Thomas, 2015; Pizer and Sexton, 2017; Renner et al., 2017).

Third, we contribute to the energy demand literature by using a censored energy consumer demand system, that creates unbiased elasticity estimates when there is lack of consumption of certain goods reported in household expenditure surveys. This method has been widely applied in food-demand contexts (Yen et al., 2002) however, it is still incipient in energy demand analysis. This paper also adds to the literature that quantifies direct and indirect household carbon footprints (Druckman et al., 2011a; Chitnis and Sorrell, 2015; Azevedo, 2014; Cohen et al., 2005; Perobelli et al., 2015; Freitas et al., 2016).

In the following section we present an overview of the recent energy tax policies implemented in Brazil (Section 1.2), then we examine the estimation strategy and data sources (Section 1.3) before moving to a discussion of the results (Section 1.4) and finally presentation of our conclusions (Section 1.5).

\subsection{Background: energy taxation on consumption}

From large-scale pioneering initiatives to promote biofuels to heavy petroleum subsidies, the strategies adopted by the Brazilian government in recent decades have

\footnotetext{
${ }^{1.8}$ These households may be cash- and credit constrained, so it is more difficult for them to replace old appliances with newer ones even though that could save them money over time. When buying new appliances, the same constraints prevent them from investing heavily in energy efficiency. This regressivity may be exacerbated if poorer households live in older, less efficient housing and use less efficient household appliances. Emission reductions from electricity price changes could also be large, depending on the electricity generation characteristics, own and cross price elasticities and budget shares (Renner et al., 2018; Renner et al., 2017).
} 
strongly influenced the current design of the country's energy consumption and emissions profile. Figure 1.2 summarizes the main landmarks discussed in this section.

Since Brazil was not an oil-rich country, domestic oil needs had to be met mainly by imports up to the $1970 \mathrm{~s}^{1.9}$. The first oil shock in 1973 hit Brazil when barely $17 \%$ of its oil were met by domestic production. After the second oil shock in 1979-80, the oil bill amounted to the financial equivalent of more than half of Brazilian exports (Rovere and Simões, 2008). As a result, an ambitious programme was launched by the government to substitute imported oil for alternative domestic energy sources. The National Alcohol Programme (PROALCOOL) encouraged the production and consumption of ethanol as a substitute for gasoline in automobiles ${ }^{1.10}$. The government also provided incentives for automobile manufacturers to develop vehicles capable of running on ethanol. In parallel, Petrobras, a state-controlled oil company, was also required to establish an oil price stabilization fund ${ }^{1.11}$ in its accounting practices ${ }^{1.12}$.

During the 1980s, the government no longer had the capacity to support the subsidies of PROALCOOL due to high foreign debt and inflation rates. Falling oil prices combined with rising sugar prices and the removal of government subsidies decreased incentive for consumers to buy ethanol-powered cars, as well as the interest of the auto industry to produce them (Rovere and Simões, 2008). Consequently, the PROALCOOL ended in 1991.

Other energy subsidies were also phased out due to privatization of the energy sector in the 1990s (Basso, 2019). Despite the reforms (Oliveira and Laan, 2010) ${ }^{1.13}$, oil incumbents did not erode Petrobras' dominant position in the oil exploration, refining and transport business as it became the preferred partner of the new companies in the search for oil on the Brazilian continental shelf. Likewise, incumbents of the electricity sector argued that Brazil was a hydropower country and a hydro-dominated electricity system was less efficient under full competition. Therefore, the influence of state-owned

\footnotetext{
${ }^{1.9}$ At that time, the country had a system of levies and cross-subsidies for the energy sector, as diesel was considered essential for industrialization, liquefied petroleum gas (LPG) was widely used for cooking and electricity prices were uneven across regions(Oliveira and Laan, 2010).

${ }^{1.10}$ The ethanol subsidies had social, regional and macroeconomic objectives, as it was produced from sugarcane, which employed a large number of unskilled laborers in rural areas, and it was promised to reduce Brazil's expenditure of hard currency for petroleum imports (Oliveira and Laan, 2010)

${ }^{1.11}$ Fundo Especial de reajuste de Estrutura de Preços dos Combustiveis e Lubrificantes (Decree-law no $1785 / 80)$.

${ }^{1.12}$ Domestic oil was priced below or above the imported oil price to keep the oil costs for Petrobras refineries set at a price determined by the government. Any deficit in the oil fund had to be reimbursed by the government (Oliveira and Laan, 2010).

${ }^{1.13}$ Law No. 9.478/1997, the Petroleum Law.
} 
hydropower actors remained even after partial privatization of the electric sector (Basso, $2019)^{1.14}$.

In the early 2000s, in response to the criticism about the liberalization of the sector by nationalists, the government introduced a new levy Contribuição de Intervenção no Dominio Econômico (CIDE) $)^{1.15}$ on the importation and sale of petroleum products (Oliveira and Laan, 2010) $)^{1.16}$. Significant changes in the Brazilian hydrological cycle drastically reduced the share of electricity generated by hydropower. It forced power generation companies to compensate the supply with costlier thermal power fueled by natural gas, biomass and coal, which increased the generation price. Despite incentives to use alternative electric sources (e.g. wind and biomass) through the creation of Conta de Desenvolvimento Energético (CDE) ${ }^{1.17}$, governmental planning and auctions prioritized large-scale hydropower and thermoelectric plants, as they were believed to provide supply security (Basso, 2019). At the same time, bioethanol production in Brazil started to grow at unprecedented rates, prompted by the introduction of flex-fuel vehicles (running on either ethanol, gasoline, or any combination of the two) and the government's strategic decision to incentivize ethanol exports, since the demand was growing in Europe and the US.

The escalation of international oil prices after 2007/08 economic crisis and the identification of large domestic offshore oil reserves (pre-salt) radically changed the government perception of the Brazilian oil situation. Tax exemptions were granted for petroleum products to minimize the effect of the rising price of oil and the economic slowdown, which led to significant losses for Petrobras and the ethanol industry, led flexfuel vehicle owners to choose the fossil option over ethanol (Oliveira and Laan, 2010) $)^{1.18}$. According to the National Petroleum, Natural Gas and Biofuels Agency (ANP), gasoline and diesel prices for the end consumer presented accumulated variations of $10 \%$ and 1\%, respectively, between 2009 and 2013, while ethanol prices increased by 33\% (ANP

\footnotetext{
${ }^{1.14}$ It is difficult to quantify the subsidy and tax levels provided to producers and consumers in the 1970-1990 period due to the lack of official figures and high inflation rates.

${ }^{1.15}$ The PIS/COFINS tax rate remained around $9.25 \%$ in the period $2002-12$. ICMS tax rates for transportation fuels differ from state to state, within the limits set by federal legislation.

${ }^{1.16}$ The levy raised revenues that were then used to fund: i) subsidies for ethanol producers; ii) the transportation costs of hydrocarbons and LPG used by low-income families; iii) projects oriented to environmental protection; and iv) the construction of roads.

${ }^{1.17}$ The Conta de Desenvolvimento Energético (CDE), created by Law 10.438/02, is a sectorial fund whose objective is to finance several public policies in the Brazilian electric sector, including the development and consumption of renewable energy sources. CDE resources are collected mainly from the annual dues paid by all agents that sell electricity to final consumers, through a tariff charge included in the tariffs for the use of energy distribution and transmission systems.

${ }^{1.18} \mathrm{As}$ an example, the CIDE rate was reduced to zero between 2012 and 2014.
} 
Agência Nacional do Petróleo, 2020).

Between 2010 and 2014, after the recovery of the electricity supply capacity, new regulations were introduced aiming to expand and diversify its capacity, and boost competitiveness and economic growth. Electricity prices were reduced by $18 \%$ for domestic consumers and $32 \%$ for industrial ones ${ }^{1.19}$ as a result of the reduction in the CDE rate. Tariff flags, a system of colors to indicate generation costs, were also implemented to inform consumers about increases and decreases in electricity prices. In an attempt to improve a largely neglected topic - energy efficiency and conservation -, the federal government offered a social levy on electricity ${ }^{1.20}$ and tax exemptions of value-added tax on manufactured goods (IPI), such as residential appliances ${ }^{1.21}$. Tax rates ranged between $0 \%$ and $20 \%$ according to the type of good ${ }^{1.22}$. As a result, there was a sharp increase in the purchase of home appliances and equipment such as computers, mobile phones, refrigerators, TVs and air-conditioners, which tended to be more energy-efficient than the older appliances they often replaced.

The political and economic crises that have held sway since 2015 have forced the government to review some energy tax and subsidy policies. For an example, CIDE was reestablished $^{1.23}$ on gasoline and diesel. Electricity prices also increased considerably as a consequence of several droughts in the Southeast region, which increased the dependency on thermal power plants. However, there is still some uncertainty about the government's final positioning on current energy taxes and subsidies. After announcing an end to diesel tax cuts and subsidies in 2018, Brazilian truckers staged a 10-day strike causing shortages of basic goods and a shortage of fuels across the country. In response, the government agreed to lower the pump price of diesel by $10 \%$.

\footnotetext{
${ }^{1.19}$ Law No $12.783 / 2013$.

${ }^{1.20}$ Law $12.212 / 2010$ - For those with per capita family income less than half the Brazilian minimum wage (approximately USD 140/month).

${ }^{1.21}$ Decrees No $7.878 / 2012$ and No 8.035/2013.

${ }^{1.22}$ For stoves, the reduction was $4 \%$; for washing machines, refrigerators and semi-automatic washing tanks it was $10 \%$.

${ }^{1.23}$ As a $\mathrm{R} \$ 0.10$ per liter tax on gasoline, and $\mathrm{R} \$ 0.05$ per liter tax on diesel.
} 


\subsection{Empirical Strategy and Data}

\subsection{1 $\mathrm{CO}_{2} \mathrm{e}$ emission coefficients}

The hybrid input-output (HIO) method is the most widely used way to link energy sources and economic production and consumption (Druckman et al., 2011b; Thomas and Azevedo, 2013; Chitnis et al., 2014). It requires the construction of the $\boldsymbol{E}_{\text {exn }}$ matrix, which represents the consumption of $e$ sources of energy from $n$ economic sectors $(e<n)$ and it is expressed in physical units (tons of oil equivalent, toe). The matrix $\boldsymbol{E}$ substitutes intermediate input flows in the energy sectors (matrix $\boldsymbol{Z}^{*}$ ), the total production vector $\left(\boldsymbol{x}^{*}\right)$ and the final demand vector $\left(\boldsymbol{y}^{*}\right)$ :

$$
\boldsymbol{A}^{*}=\boldsymbol{Z}^{*}\left(\hat{\boldsymbol{X}}^{*}\right)^{-1}
$$

where $\boldsymbol{X}^{*}$ is a matrix with the elements of $\boldsymbol{x}^{*}$ in the diagonal and zeros elsewhere and $\boldsymbol{A}^{*}$ is the technical coefficient matrix, in hybrid units.

Energy requirements are converted into $\mathrm{CO}_{2}, \mathrm{CH}_{4}$ and $\mathrm{N}_{2} \mathrm{O}^{1.24}$ and then to $\mathrm{CO}_{2} \mathrm{e}$ based on energy conversion coefficients for fossil fuels ${ }^{1.25}$ available at the Second Brazilian Inventory of Greenhouse Gas Emissions, which follows the IPCC Guidelines for National Greenhouse Gas Inventories (IPCC, 2007) and global warming potential (GWP) conversion factors ${ }^{1.26}$.

We calculate matrix $\boldsymbol{A}_{p}$ based on the proportion of each good $i$ used in the total production of a specific sector $j(\boldsymbol{B})$, and the proportion of a sector $j$ in the national production of each good $i(\boldsymbol{D})$. Its coefficients can be interpreted as the quantity of $\mathrm{CO}_{2} \mathrm{e}$ that good $i$ uses to produce one unit of good $j$ (expressed in tons of $\mathrm{CO}_{2} \mathrm{e} / \mathrm{USD}$ million). Direct $\mathrm{CO}_{2} \mathrm{e}$ emission is equivalent to the sum the $k$ rows of $\boldsymbol{A}_{p}$ that measure

\footnotetext{
${ }^{1.24} \mathrm{CO}_{2}, \mathrm{CH}_{4}$ and $\mathrm{N}_{2} \mathrm{O}$ are the three main long-term drivers of climate change.

${ }^{1.25}$ The following fuels were considered: natural gas, steam coal, metallurgical coal, diesel oil, fuel oil,gasoline, LPG, kerosene, gas coke, coal coke, other oil byproducts, and coal tar.

${ }^{1.26}$ The "global warming potential" (or "GWP") of a GHG indicates the amount of warming a gas causes over a given period of time (normally 100 years). GWP is an index, with $\mathrm{CO}_{2}$ having the index value of 1 , and the GWP for all other GHGs is the number of times more warming they cause compared to $\mathrm{CO}_{2}$. E.g. $1 \mathrm{~kg}$ of methane causes 25 times more warming over a 100 year period compared to $1 \mathrm{~kg}$ of $\mathrm{CO} 2$, and so methane has a GWP of 25 . These conversion coefficients take into account the characteristics of the chemical process and technology applied to each greenhouse gas.
} 
emissions:

$$
c_{i, C O_{2} e q}=\sum_{k} a p_{k j}
$$

in which $k \leq i$. Total emissions are equivalent to direct plus indirect emissions:

$$
c_{i, C O_{2} e}^{T}=\left(I-\boldsymbol{A}_{p}\right)^{-1} * Y * c_{i, C O_{2} e}
$$

where $Y$ is the vector of final demand. Therefore, the emission coefficient of the goods corresponds to the $\mathrm{CO}_{2}$ e content embedded in one monetary unit of the respective good.

The HIO model assumes no price substitution effect on consumption or production processes and it considers that all interactions among components of the economy occur at the same time. However, the premise of strict prices is adjusted by the estimation of a censored demand system, as detailed in Section 1.3.2. Therefore, emissions reductions are exclusively due to consumption changes. Our emission coefficient estimates include exports but exclude imports, as it is not possible to calculate their respective energy requirements.

\subsubsection{Data}

We use energy requirement data from the Brazilian Energy Balance (BEN), from the Ministry of Mines and Energy (MME), which provides 24 energy sources ${ }^{1.27}$ consumed by 21 economic sectors. The national input-output matrix for 2010 is built based on Supply-Use Tables (SUTs) provided by the Brazilian Institute of Geography and Statistics (IBGE) (Guilhoto et al., 2010). The SUTs contain information on production and intermediate consumption, in monetary units, of 128 goods and 68 economic sectors. We follow Montoya et al. (2014) by reconciling the economic sectors from these databases and the energy sources from BEN which are compatible with the goods in SUTs (Table 1.1, Appendix).

\footnotetext{
${ }^{1.27}$ Energy generated by self-producers is not added since the majority of this energy is consumed by the same companies, and therefore, does not generate added value. Imported energy (which corresponded to approximately $7 \%$ of total energy supply in 2010) is also not included in our calculations since it is not possible to identify its respective sources.
} 


\subsubsection{Household elasticities: Censored QUAIDS}

To estimate the distributional impacts of energy taxation, we need to understand how consumers responds to price changes. We estimate price and expenditure elasticities for the household consumption basket, which are then used to compute changes in consumption following the energy taxation policies.

The advantage of estimating a system of demand equations instead of individual equations relies on the joint estimation and empirical tests concerning the validity of the theoretical restrictions implied by the consumer theory. We choose the Quadratic Almost Ideal Demand System (QUAIDS) (Deaton and Muellbauer, 1980a), which considers the non-linearity of income. It is preferred to other demand systems because it gathers many of their respective properties without making strong assumptions on preferences which could create a specification bias in the estimation. QUAIDS considers the consumption of $n$ different categories of goods and the share of each good in total household expenditures:

$$
w_{i}=\alpha_{i}+\sum_{j=1}^{n} \gamma_{i j} \ln \left(p_{j}\right)+\beta_{i} \ln \left[\frac{m}{a(\boldsymbol{p})}\right]+\frac{\lambda_{i}}{b(\boldsymbol{p})}\left[\ln \left(\frac{m}{a(\boldsymbol{p})}\right)\right]^{2}
$$

where $i$ and $j$ represent goods and $w_{i}$ the share of expenditure of good $i$ in total expenditures $m, p_{j}$ is the price index, and $a(\boldsymbol{p})$ and $b(\boldsymbol{p})$ are two distinct price indexes. We also account for household heterogeneity by including demographic and socioeconomic shifters in $\alpha_{i}$ (Pollak and Wales, 1981) (Table 1.3, Appendix).

We follow Druckman et al. (2011a) and Schmitz and Madlener (2017) by estimating the demand system for nine $(n=9)$ groups of goods, which allows the understanding of the consumption dynamics between direct and indirect energy use goods: (i) food and beverages, (ii) recreation, culture and education, (iii) clothing and footwear, (iv) commuting and transportation, (v) health and hygiene, (vi) energy (electricity and gas ${ }^{1.28}$, gasoline, ethanol, diesel and charcoal), (vii) housing (residential appliances), (viii) other goods and (ix) other services. Table 1.2 (Appendix) provides a detailed description of these categories.

Our use of household expenditure survey data to estimate the demand system, it can create biased results due to the lack of consumption of certain goods during the recall period (See Section 1.3.2.1 and Table 1.5, Appendix). We account for the problem

\footnotetext{
${ }^{1.28} \mathrm{We}$ are not able to split electricity from gas as these products are aggregated in the SUTs.
} 
of censored dependent variables using the procedures suggested by Shonkwiler and Yen $(1999)^{1.29}$, in which the consumption of each good can be characterized as a two-stage decision: the first step corresponds to a probit model with the same variables as the QUAIDS model, in which its cumulative distribution $(\hat{\Phi})$ and the probability density function $(\hat{\phi})$ are used in the second step to augment the QUAIDS estimation:

$$
w_{i}^{*}=\hat{\Phi}_{i} w_{i}+\hat{\phi}_{i}
$$

The expenditure (Eq. 1.6) and price elasticities (compensated, Eq. 1.7 and uncompensated, Eq. 1.8) formulas for the nonlinear QUAIDS can be expressed as:

$$
\begin{gathered}
\eta_{i}=1+\Phi_{i} / w_{i}\left[\beta_{i}+\left(\frac{2 \lambda_{i}}{b(p)}\right) \ln \left(\frac{m}{a(p)}\right)\right] \\
\epsilon_{i j}=-\delta_{i j}+\Phi_{i} / w_{i}\left[\gamma_{i j}-\left(\beta_{i}+\left(\frac{2 \lambda_{i}}{b(p)}\right) \ln \left(\frac{m}{a(p)}\right)\right)\left(\alpha_{j}+\sum_{k} \gamma_{j k}-\ln p_{k}\right)-\frac{\lambda_{i} \beta_{i}}{b(p)}\left(\ln \left(\frac{m}{a(p)}\right)\right)^{2}\right.
\end{gathered}
$$

where $\delta_{i j}$ is the Kronecker delta (equal to one only for own price elasticities, and zero otherwise).

$$
\epsilon_{i j}^{H}=\epsilon_{i j}+\left(\frac{\beta_{i}}{w_{i}}+1\right) w_{j}
$$

These elasticities should be interpreted as short-term impacts or upper bounds on long-term impacts since averting behavior and substitutions among goods might change demand responses in the long-run (Pizer and Sexton, 2017). Elasticities are calculated for the overall sample and for the $20 \%$ richest and $20 \%$ poorest households in the dataset to capture the heterogeneous effects of the energy tax policies. All models were estimated by feasible generalized non-linear least squares (FGNLS), and standard errors are computed by nonparametric bootstrap with 1000 repetitions. Since $\alpha_{0}$ is difficult to estimate (Deaton and Muellbauer, 1980b), we follow Boysen et al. (2012) and adopt an arbitrary and low value of 5 . Other values do not change the resulting elasticities but cause the procedure to require many more iterations to converge. Robustness checks are also conducted using an uncensored QUAIDS and AIDS models with neighboring prices and disposable income as instruments, following Poi et al. (2012).

\footnotetext{
${ }^{1.29}$ Based on the seminal work of Heien and Wesseils (1990).
} 


\subsubsection{Data}

The empirical estimation of a demand system requires household expenditure data. We use the Brazilian Household Budget Survey (POF), carried out by the IBGE from May, 2008 up to May, 2009. The survey is cross-sectional and nationally representative, with 55,970 households, and it is built based on a two-stage cluster sample: first, previously grouped census sectors are selected to obtain a stratum of households with a high level of geographic, social, and economic homogeneity; and second, households are selected by simple random sampling without replacement, from each of the selected sectors.

Households are evaluated throughout the 12 months of the survey and data collection includes all household monetary and non-monetary expenses ${ }^{1.30}$, which are annualized and subject to deflation. Recording periods are also different according to the good/service: food and beverage expenses are collected for a 7-day period; building materials expenses, rent and taxes are compiled for a 12-month period; expenses related to the consumption of energy goods (electricity and gas and transport fuels) are collected for a 90-day period, while individual expenses with transportation, education, meals outside the home, medicines, hygiene, health, furniture and vehicle acquisition vary according to the good/service; and income data corresponded to a 12 month period. The level of detailed information of monetary and non-monetary expenses and income from POF allows minimizing of the under-declaration problem (Hoffmann, 2010).

In the POF, the IBGE provides information for almost 14,000 products, while the most recent and disaggregated data from SUTs present only 128 products. To reconcile both datasets, we use the IBGE official translator to match POF products according to their similarity with the products available from the SUTs ${ }^{1.31}$.

\subsubsection{Construction of price aggregates}

The main theoretical variables for household demand system are, basically, total expenditures (proxy for income) $)^{1.32}$ and prices, calculated as unit values $\left(p_{i}=U V_{i}\right)$.

\footnotetext{
${ }^{1.30}$ Monetary expenses includes all means of payment, on demand or over a period of time, in cash or by check or credit card. Non-monetary expenses correspond to acquisitions by means of donations, taken from the business, own production, fishing, hunting or gathering.

${ }^{1.31}$ Available at: < https://www.ibge.gov.br/estatisticas/economicas/contas-nacionais/ 9052-sistema-de-contas-nacionais-brasil.html?edicao=25916\&t=notas-tecnicas. $>$

${ }^{1.32}$ Since household income is self-reported, this information might be associated with negative reporting bias. To overcome this issue, the literature usually adopts household total expenditure as a
} 
Particularly for the products from group 1 (food and beverages), there are two main problems related to the price we calculate from the household expenditure surveys: potential measurement error, and differences in quality and packaging (Boysen et al., 2012). We use a price correction method based on Cox and Wohlgenant $(1986)^{1.33}$, detailed in Appendix B.

As not all households have positive consumption of all items, the missing observations are approximated by the average of $\hat{p}_{i}$ coefficients over the neighboring region - first, the state and, if it is still missing, the census sector. After the price corrections for each item belonging to each of the nine groups, we compute the Stone price index (Deaton and Muellbauer, 1980a), whose heterogeneity provides suffient variability to cross-sectional datasets:

$$
\ln p_{n}=\sum_{i \in I_{n}} w_{i} \ln p_{i}
$$

in which $I_{n}$ is the set of items included in aggregate item group $n, p_{i}$ is the price and $w_{i}$ is the budget share for item $i$ of each household. Because expenditures and prices are endogenous in this demand system, we use household disposable income as an instrument for expenditures, and nearest neighbors price indexes as instrument for household price indexes(Lecocq and Robin, 2015), controlling for diversity in household preferences such as composition, age, location and energy use inventory.

In the POF, there is a limitation related to the lack of specification of the quantity consumed of several goods and services particularly consumed: in a 12-month period (e.g. rent, taxes, construction and remodeling) and on an individual basis (e.g., education, commuting and transportation), mainly aggregated into groups 2, 4, 5, 7 and 9. To overcome this issue, we assume that the quantity consumed is equal to 1 for the households with positive consumption of the respective good/service. This approach tends to overestimate the unit value for some products and services, thus underestimating the respective price-elasticities.

\footnotetext{
proxy for household income.

${ }^{1.33}$ Deaton (1990) also proposes a procedure to correct unit values, assuming that there are no price variations within a geographic area near the households. The variations observed in unit values for household in a given area are due to quality differentials and measurement errors of the goods previously acquired. That is, for households physically close to each other, the reported price should be the same in a similar period of time. Besides its difficulty of implementation - due to a large matrix multiplication -, the main disadvantage of Deaton's method is that the covariance of the residuals which is used to estimate corrected price elasticities - can be influenced by many unexplained factors and not just price variation.
} 
Based on these limitations, Table 1.4 presents the aggregated prices, in which values expressed in reais of 2009 are converted to 2019 using the average exchange rate from the Central Bank of Brazil for the latter year. The price indexes should be interpreted as a relative price index: for example, richer households expend 34\%, $78 \%$ and $67 \%$ more on food and beverages, commuting and transportation services and energy goods, respectively, than the poorest households. The small standard deviation values are associated with the lack of information related to quantity consumed of several expenditure items.

The expenditure share of energy goods by different income levels is presented in Table 1.6. Energy consumption in Brazilian households includes electricity and gas and transportation (ethanol, diesel and gasoline). On average, the majority of household expenditures refer to electricity and gasoline consumption. Richer households present a smaller expenditure share for electricity compared to poorer households. However, expenditure shares for fuel are smaller for poorer households.

\subsubsection{Policy simulation}

\subsubsection{Scenarios}

We simulate de facto changes in ad valorem tax rates on final consumer prices of household energy goods implemented by the Brazilian government in recent decades as discussed in Section 1.2. Since tax and subsidy rates applied to gasoline, ethanol and diesel varied considerably over time, we use a $10 \%$ tariff rate as reference. Similarly, since tariff rate reduction also varied among residential appliances, we also adopt a $10 \%$ tariff rate in our calculations. For electricity, we use the rates announced by the Brazilian government in 2013 - reduction of approximately 20\%. As shown in Table 1.7 (Appendix), scenarios 1-4 include subsidy on diesel, subsidy on electricity, tax on gasoline and subsidy on residential appliances.

We compare the results of the de facto policies with results of more environmentally friendly simulated policies. Scenarios 5-9 include hypothetical policies that promote the use of cleaner alternative transport fuels - tax on diesel, subsidy on ethanol, combined tax on transportation fuels (gasoline and diesel) and subsidy on ethanol - and improvements in household energy efficiency - subsidy on residential appliances and tax on electricity. 


\subsubsection{Welfare effects}

Focusing only on the costs associated with the tax imposition and assuming that prices are fully transferred to consumers (Flues and Thomas, 2015; Boyce, 2016), we use the concept of compensating variation $(\mathrm{CV})$ to assess the short-term effects of energy taxes on welfare. The CV, expressed in monetary terms, indicates the adjustment in income a household would need to re-establish its initial utility after a tariff-induced change in prices. CV can be decomposed into two components: (i) the tax burden (TB), that is, the variation in the price multiplied by the quantity consumed after the price change, and (ii) the excess tax burden (EB), which is the efficiency cost or deadweight loss.

The effective tax rate $\tau_{n}$ is calculated based on the overall changes in the group price index: electricity and gas and transport fuel prices impact the price index for the energy group, and changes in residential appliances prices affect the overall price index for housing, such as:

$$
\tau_{n}=\sum_{i \in I_{n}} w_{i}^{0} \ln p_{i}^{1}-\sum_{i \in I_{n}} w_{i}^{0} \ln p_{i}^{0}
$$

Considering $\tau_{n}$ and the compensated elasticities obtained from Equation 1.7, changes in quantities can be calculated as:

$$
\frac{\Delta q_{i}}{\bar{q}_{i}}=\sum_{j=1}^{n} \hat{\varepsilon}_{i j}^{H} \tau_{i}
$$

As to the approximation suggested by Harberger $(1971)^{1.34}$ :

$$
E B_{C V i}=\left(p_{i}^{1}-p_{i}^{0}\right) \frac{\left(q_{i}\left(p_{i}^{1}, p_{-i}, m\right)-h_{i}\left(p_{i}^{1}, p_{-i}, U_{0}\right)\right)}{2}
$$

\footnotetext{
${ }^{1.34}$ Traditional Harberger-triangle formulas assume that the market demand curve comes from utility maximization and that either taxes are small or demand functions are linear. Therefore, the use of this approximation is good for small policy changes, but can be inaccurate for large ones. Despite assuming linearity of the supply and demand curves, the benefit of this method is that it can be used for any type of model if the prices and quantities before and after a policy change are available.
} 
and

$$
\Delta T B_{i}=\frac{\tau_{i}}{1+\tau_{i}} p_{i}^{1} \times q_{i}\left(p_{i}^{1}, p_{-i}, m\right)
$$

A key issue to examine the distributional effects of carbon taxes is how to measure the magnitude of tax burdens between poor and rich households. Many households in the lower income deciles either dis-save on previous earnings or may borrow against future earnings. Their level of expenditure reflects better what they are able to afford than their levels of income (Flues and Thomas, 2015). Since current consumption measures the current standard of living better than current income, we present CV, EB and TB estimates relative to the total household expenditures.

\subsubsection{Emission effects}

Based on total emission coefficient for each good and service $i$, we create a weighted emission coefficient for each of the 9 groups for the overall sample and the $20 \%$ poorest and $20 \%$ richest households. The difference between total GHG emissions before and after the tariff rate changes indicate the changes in total household carbon footprints due to a specific energy tax policy, as follows:

$$
\Delta C O_{2} e=\sum_{n}\left(p_{i}^{1} * q_{i}^{1}\right) * c_{i, C O_{2} e}^{T}-\sum_{n}\left(p_{i}^{0} * q_{i}^{0}\right) * c_{i, C O_{2} e}^{T}
$$

\subsection{Results}

In this section we present the $\mathrm{CO}_{2} \mathrm{e}$ emission coefficients from the burning of fossil fuels and the elasticities estimates. At the end, we show calculations of the welfare and emissions effects of several price change scenarios, followed by a cost-effectiveness calculation to compare alternative policies.

\subsection{1 $\quad \mathrm{CO}_{2} \mathrm{e}$ emission coefficients}

Based on the $\mathrm{HIO}$ method, the $\mathrm{CO}_{2} \mathrm{e}$ emission coefficients for each good in the economy are shown in Table 1.9. The intermediate consumption coefficient represents 
only direct emissions, which counts the $\mathrm{CO}_{2}$ e required to produce USD 1 million of output of each good/service, in 2019 values. The final demand coefficient, in turn, includes direct and indirect emissions, indicating how much $\mathrm{CO}_{2} \mathrm{e}$ is generated throughout the production chain (final demand).

Our estimates show that services under group 4 (commuting and transportation), composed of ground transportation of cargo and passengers, as well as air and water transportation, are the most carbon intensive services in the Brazilian economy. Goods included in groups 7 (housing) and 8 (other goods), which encompass products such as wood and paper products, cement, glass, metal and electrical machinery, such as residential appliances, also present high emission coefficients. Foods and beverages have high $\mathrm{CO}_{2} \mathrm{e}$ levels mainly due to indirect effects from transportation. Since freight and passenger transportation is heavily based on road and buses and trucks that use diesel as the main fuel, indirect emissions account for the largest part of overall emissions.

These results are aligned with previous studies conducted specifically involving Brazilian households. Cohen et al. (2005) found that utilities, mobility (transportation) and housing accounted for the majority of energy consumption in $1995^{1.35}$. An interesting point raised by the authors was that, in general, energy intensities varied considerably across the income classes, except for mobility (because of the shift from public to individual transport) and housing (due to differences among rents and residential appliances between classes). Perobelli et al. (2015) found that most $\mathrm{CO}_{2} \mathrm{e}$ emitted by Brazilian households in 2003 and 2009 came from transportation services, electricity, gas and water supply, as well as food products. Unlike other sectors, the share of $\mathrm{CO}_{2} \mathrm{e}$ emissions from transportation services increases with income level.

This pattern can also be observed in other empirical studies. Using an environmentallyextended input-output model, Thomas and Azevedo (2013) showed that gasoline and electricity accounted for the largest share of the average U.S. household footprint in 2002. Findings from Kerkhof et al. (2009) indicated that Dutch households used gas for home heating and cooking, with a high contribution to $\mathrm{CO}_{2} \mathrm{e}$ emissions. Therefore, high emission intensity mainly originates from the use of gas and electricity (which are included in the housing group in their study), followed by food products due to indirect emissions. Based on an input-output model for carbon emissions, housing is the main source of $\mathrm{CO}_{2} \mathrm{e}$ emitted by Chinese households, followed by food, transportation and electricity (Fan et al., 2012; Golley and Meng, 2012).

\footnotetext{
${ }^{1.35}$ The energy intensity was defined as the total primary energy requirement of the product basket of a category divided by the total consumer price of that product and is expressed in MJ/US\$ 1996 PPP.
} 
Considering the total expenditures from POF, and the estimated $\mathrm{CO}_{2} \mathrm{e}$ emission coefficients, Table 1.8 presents the total $\mathrm{CO}_{2} \mathrm{e}$ emission by income level. For energy goods, richer households emit almost 10 times more than poorer households; for commuting and transportation services, this proportion is significantly higher (80 times more). For housing and food and beverages, richer households tend to emit 5 and 15 times more when compared to poorer households, respectively. According World Bank estimates (Bank, 2014), the average emission per household in Brazil was approximately $10 \mathrm{tCO}_{2} \mathrm{e}$ in 2014, roughly in line with the average of $10.5 \mathrm{tCO}_{2} \mathrm{e}$ resulting from our approach. Furthermore, taking 2014 World Bank statistics as a benchmark, we find that the average emissions per household in Brazil is significantly lower than the global average. Indeed, the average $\mathrm{CO}_{2} \mathrm{e}$ emissions of the richest quintile in Brazil is below the average emission considering only $\mathrm{CO}_{2}$ in China (30 tCO 2 /household), Germany (35 tCO 2 /household) and the United States (66 tCO 2 /household). Likewise, the average $\mathrm{CO}_{2}$ e emissions of the poorest quintile is much lower than the average $\mathrm{CO} 2$ emission in India $\left(7 \mathrm{tCO}_{2} /\right.$ household).

\subsubsection{Price and expenditure elasticities}

Table 1.12 presents short-term expenditure, own and cross price elasticities for the entire household consumption according to different income levels. Likewise, Table 1.13 shows the same estimates disaggregated for energy goods and residential appliances.

The expenditure elasticities for domestic energy goods are relatively high (1.8), indicating they are luxury goods for all levels of income - especially for the poorest households (1.9). We find a stronger positive relationship between income levels and ethanol and diesel consumption, while electricity, gas and gasoline are mainly considered essential goods. In contrast, expenditure elasticities for housing are relatively low (0.5) particularly for high-income groups (0.2). However, residential appliances, in particular, are considered luxury goods for all households. Interestingly, for richer households, commuting and transportation services are considered essential goods (0.9), while for poorer households they can be classified as superior goods (1.9). Similar results were found for developing countries by Renner et al. (2017) (Mexico), Renner et al. (2018) (Indonesia), and Perobelli et al. (2015) (Brazil), as well as for developed countries by Schmitz and Madlener (2017) (Germany) and Brännlund et al. (2007) (Sweden). In general, there is an increasing propensity to consume fuel for mobility as income (and therefore expenditures) grows; therefore, the public transport expenditure share tends 
to decline over the expenditure distribution.

All uncompensated own-price elasticities show the expected negative signs and reflect a relatively inelastic household response to energy price changes, particularly for electricity and gas, ethanol and gasoline. For these transport fuels, given the fact that car and motorcycle ownership are strongly correlated with household income, and the great majority of Brazil's vehicles are flex-fuel, richer households present relatively higher price-elasticity. They also tend to be more responsive to diesel price changes compared to poorer households. Compared to other countries, Brazil presents a consistently greater price elasticity for light transport fuels, which can be mainly explained by the country's automobile fleet characteristics (Dahl, 2012; Labandeira et al., 2017). This elasticity is closer to international long-term elasticity estimates (Sterner, 2012). Commuting and transportation services, as well as housing, present a lower price elasticity - especially for poorer households. Significant differences in own-price elasticities are observed according to household income level for food and beverages, housing, clothing and footwear and other goods and services.

Compensated-price elasticities, used in the calculation of welfare effects, differ from uncompensated elasticities since expenditure elasticities are mainly higher than or close to 1. For energy goods, the discrepancy between the compensated (Table 1.15) and uncompensated (Table 1.14) elasticities and the high expenditure elasticity suggest that own-price response is primarily driven by expenditure effects. These effects are less evident for commuting and transportation services, as well as housing and food and beverages. In particular, the differences between compensated and uncompensated price elasticities for diesel and gasoline between income-levels indicate that low-income households might be more responsive to taxes or subsidies on these transport fuels (Levinson and O'Brien, 2015), despite their relatively small expenditure share of these goods.

Cross price elasticites (Tables 1.12, 1.14 and 1.15) indicate that, in general, the groups with high $\mathrm{CO}_{2} \mathrm{e}$ emission coefficients are substitutes for energy goods, that is, food and beverages, housing, and especially, commuting and transportation services. Food and beverages are also substitutes for housing and commuting and transportation services, and the latter are also a substitute for housing. However, housing is a complementary good for commuting and transportation services. Likewise, energy goods appear to be complementary for housing.

In general, the findings suggest that the expenditure effects for energy goods 
outweigh the substitution effects, and changes in their price will have an impact on the demand for high $\mathrm{CO}_{2} \mathrm{e}$ intensity goods. Changes in the quantity demanded of other groups (such as housing) appear to have much smaller impact on the consumption of other goods and overall $\mathrm{CO}_{2} \mathrm{e}$ emissions.

\subsubsection{Tax simulations: Welfare and emissions effects}

The impacts of different energy tax policies are presented in Table 1.16. As a result of the small share in household expenditures, a 10\% subsidy on diesel prices - as recently announced by the Brazilian government - tends to generate a lower tax burden and relatively small economic inefficiencies. On the environmental side, since diesel is the main fuel used for cargo and passenger transportation, subsidies applied to this good increase $\mathrm{CO}_{2} \mathrm{e}$ emissions by $4 \%$ per year, which would be equivalent to $0.6 \%$ of total energy emissions in 2018 (407 $\mathrm{MtCO}_{2} \mathrm{e}$ ) (BRASIL, 2020).

Since electricity and gas account for more than $60 \%$ of total household expenditure, changes in their price tends to generate more substantial compensating variation, economic inefficiencies and reductions of tax burden. However, since the tax burden is almost double for the poorest households, an increase in electricity prices can be considered a regressive policy. The $20 \%$ subsidy on electricity and gas prices, implemented in 2013 , could have decreased $\mathrm{CO}_{2} \mathrm{e}$ emissions by almost $17 \%$, as hydropower supplies more than 3/4 of Brazil's electricity. The reduction in the overall emissions comes mainly from richer households: despite the increase in the consumption of energy goods, there is a reduction in the consumption of high intensity $\mathrm{CO}_{2} \mathrm{e}$ services such as commuting and transportation, which explains the overall reduction of $\mathrm{CO}_{2} \mathrm{e}$ emissions. The effect of changes in the price of electricity is also enhanced due to the large electricity coverage: in 2009, 97\% of Brazilian households had access to reliable electricity (see Table 1.3).

Tax on gasoline appears to affect mainly richer households, so it can be understood as progressive. On the environmental side, a $10 \%$ increase in gasoline prices generates an equivalent $6.3 \%$ increase in total $\mathrm{CO}_{2} \mathrm{e}$ emission per year, which amounted to $1.0 \%$ of the country's total energy emissions in 2018. Despite the decrease in total gasoline consumption, and consequently total consumption of energy goods, there is an increase in the demand for $\mathrm{CO}_{2} \mathrm{e}$-intensive goods (such as food and beverages) as well as commuting and transportation services. However, this is the case mainly for richer households, as total emissions from the poorest remain at pre-tax levels. 
Tax cuts on residential appliances, similar to the VAT (IPI) tax exemptions implemented in 2013, appear to benefit richer households more, as shown by the differences in the tax burden. Annual $\mathrm{CO}_{2} \mathrm{e}$ emissions could have increased by approximately $3 \%$ due to this policy, as a result of the increase in total emissions from richer households. The environmental impact represents $0.5 \%$ of current energy emission levels. However, poorer households present no reduction in total emissions. In particular, these results are aligned with Gertler et al. (2016), Caron and Fally (2018) and Levinson and O'Brien (2015), who showed that household credit constraints make them much more likely to purchase energy-using assets with additional income once their income passes a threshold level.

Considering that almost $59 \mathrm{MtCO}_{2}$ e were additionally released by the energy sector between 2010 and 2018 (BRASIL, 2020), our estimates suggest that $11 \%$ (or 6.5 $\mathrm{MtCO}_{2} \mathrm{e}$ ) of these emissions could have been averted in the absence of combined tax cuts/subsidy on residential appliances, diesel and electricity, and tax increases on gasoline prices. This overall result is mainly driven by the large and positive environmental effects from a subsidy on end consumer electricity prices. When excluding this policy, the results are more expressive: $2.1 \%$ of current emissions from the energy sector could have been avoided annually, which amounts to $8.5 \mathrm{MtCO}_{2} \mathrm{e} /$ year or $116 \%$ of the difference between 2010 and 2018 GHG emission levels.

Interestingly, a hypothetical increase in the price of diesel presents an asymmetric effect when compared to the subsidy: the former has a lower effect on households' total expenditure, economic efficiency and emissions. As several studies point out, price reactions in energy demand can be asymmetric (Gately and Huntington, 2002; Frondel and Vance, 2013).

Tax policies that promote a more sustainable and renewable energy mix seem to be progressive. However, except for an ethanol subsidy, they do not generate fewer economic distortions or substantial reductions in total $\mathrm{CO}_{2}$ e emissions, mainly due to the consumption behavior of richer households (Perobelli et al., 2015; Cohen et al., 2005). In this sense, our simulation of a subsidy on end consumer price of ethanol do not consider the negative effects on the overall environment, such as on land use, soil erosion, fertilizer use, and wildlife habitat (Malcolm et al., 2009), as well as on human health (Jacobson, 2007).

These tax policies directly affect the government's budget. By considering the average tax burden on households, and taking into account the estimate of total 
permanent households from the 2010 Population Census (57.2 mi households), it is possible to calculate the impact of each scenario on state revenue. A large impact would be observed with subsidies on electricity as the federal budget would decrease by USD 10.1 bi, followed by tax cuts on residential appliances (USD $3.5 \mathrm{bi}$ ), the combined tax policy aiming at improving energy efficiency (USD $1.8 \mathrm{bi}$ ) and the subsidy on diesel (USD $0.5 \mathrm{bi}$ ). Nonetheless, tax increases on gasoline would potentially provide a USD 5.1 bi increase in federal revenue. This would policies to promote the use of ethanol and reduce transportation fossil fuels (diesel and gasoline), as central government budget could increase USD 4.7 bi and USD 5.0 bi under scenarios 7 and 8, respectively. These increases are considerable, as revenue from CIDE (levy on the imports and sale of petroleum products) accounted for USD 6.9 bi in 2019. All of this suggests that these revenue streams could be used by the government as an option to reduce the regressiveness of specific tax policies, such as increases in electricity prices.

Our results suggest that energy efficiency policies, such as promoting the purchase of more energy efficient goods by subsidizing new residential appliances and taxing electricity and gas, overburden the most vulnerable households and generate an overall increase of total $\mathrm{CO}_{2} \mathrm{e}$ emissions. Taking into account cross-price elasticities and the differences in expenditure shares between income levels, our results suggest that energy tax policies might not be as efficient as they seem at reducing GHG emissions. Similar to the findings of Freitas et al. (2016) and Grottera et al. (2017), we expect that an economy-wide $\mathrm{CO}_{2}$ e tax could worsen economic disparities by imposing a relatively heavier burden on low-income households.

Finally, when we calculate a cost-effectiveness measure of the policies - by dividing the $\mathrm{EB}$ (cost of policy) by the $\mathrm{CO}_{2 e}$ reduction ${ }^{1.36_{-}}$, we note that the subsidy on ethanol is 34 times more effective in reducing emissions. While for the full (rich) sample the cost of reducing emissions by 1 ton of $C_{2 e}$ is USD 1/year (USD 2.7/year) for the subsidy on ethanol, the subsidy on electricity and gas generates a cost of USD 34.31/year (USD 31.6/year) for the same reduction in emissions. Both costeffectiveness measures are still lower than the current values of the social cost of carbon (SCC) of 62 USD per $t C O_{2 e}{ }^{1.37}$ However, considering the only policy that reduces emissions for the poorest (20\% subsidy on electricity and gas), the cost to reduce each ton of CO2 emissions is USD 183 per year.

\footnotetext{
${ }^{1.36} \mathrm{We}$ calculate this measure only for policies that have reduced $\mathrm{CO}_{2 e}$ emissions.

${ }^{1.37}$ The SCC is the incremental monetized global damages from an additional unit of $\mathrm{CO} 2$ emitted to the atmosphere. We use US government estimates for global SSC considering a long-term discount rate of $2.5 \%$ per year.
} 
Our findings are aligned and support the international literature on distributional patterns of energy taxes and subsidies. These indicate that price changes in transport fuels seem to be less regressive than changes in prices of other energy goods, such as electricity and residential appliances. Tax policies on gasoline and diesel have been shown to be strongly progressive in African and large Asian countries, as well as in Turkey, Chile, Mexico, Costa Rica and Brazil (Pizer and Sexton, 2017; Williams et al., 2014; Lozada and Sterner, 2012; Sterner, 2012; Renner et al., 2018). However, the results of taxes and subsidies applied on electricity vary among countries, mainly due to electricity coverage. Many poor households in developing countries do not benefit from lower electricity tariffs because many do not have access to it and many with larger family sizes (driven by the number of children) consume at levels above "lifeline thresholds" (Coady et al., 2015).

\subsection{Conclusions}

The recent trend in Brazilian GHG emissions indicates that a larger share of $\mathrm{CO}_{2} \mathrm{e}$ emissions is being generated by the energy sector. At the same time, energy tax policies have been used by the Brazilian government as a lever for policy targets without necessarily considering the environmental effects. Understanding who benefited from these policies and their environmental impacts are keys to gaining public support for a greener energy mix, as pledged by the country in its NDC.

In this paper, we estimated short-term emissions and distributional effects of energy price changes in a partial equilibrium framework. The recent taxes introduced on gasoline prices appear to be progressive and have a negative impact on total household emissions due to substitution effects. The same was observed for policies that reduce the end consumer price of residential appliances. Despite being regressive, changes in electricity and gas prices have a considerable effect on household emissions due to the particularities of the Brazilian electric supply and coverage. Similarly, taxes applied on diesel can also be regressive, but they do not impact the current $\mathrm{CO}_{2}$ e emission levels. We estimate that $11 \%$ of total energy emissions between 2010 and $2018\left(6.5 \mathrm{MtCO}_{2} \mathrm{e}\right)$ could have been avoided in the absence of combined tax cuts/subsidy on residential appliances, diesel and electricity, and tax increases on gasoline prices.

By simulating hypothetical price change scenarios for tax policies considered more environmentally friendly, the evidence shows there are significant tradeoffs between 
welfare and emissions. Alternative policies that subsidize ethanol have a small but positive effect on the economy and tend to reduce household emissions in a more cost-effective way. However, large substitution effects when also taxing gasoline do not offset the reduction in emissions caused by a lower ethanol price. Policies that promote a more efficient use of electricity are regressive and could increase household carbon footprints.

We show that distributional effects on welfare are a crucial factor to be taken into account when designing policies to reduce GHG emissions. Aligned with the international empirical evidence, our evidences show that a very large share of the benefits from energy price subsidies might be appropriated by high-income households, aggravating existing income inequalities. Our findings emphasize the need to consider compensating schemes aiming at lowering the burden on the poorest households when energy taxes are designed and implemented.

The regressivity and progressivity of energy taxes are likely to change over time. Further analysis is required to understand the long-term consumption patterns and the potential emission effects associated with energy tax policies. More in-depth studies should also analyze to what extent the effects of non-price instruments (such as feed-in-tariffs or energy efficiency standards) or an economy-wide carbon ${ }^{1.38}$ tax would differ from the findings presented in this study.

Our results are influenced by the adopted methodological approach, and some aspects of this should be emphasized. First, tax burdens and economic welfare are measured against expenditures, which compared to disposable income, can make taxes and subsidies appear less regressive (Rausch et al., 2011; Poterba, 1991). Second, since we focus on short term impacts, we do not take into account that households may adjust consumption patterns in response to tax changes (Pizer and Sexton, 2017; Morris and Sterner, 2013). Third, we assume that the taxes and subsidies are fully passed on to consumers. Energy pricing may change real wages and returns to capital, which can influence the optimal input production (and hence emissions) of various sectors (Boyce, 2016; Flues and Thomas, 2015). Fourth, our analysis focuses on the distributional costs of tax policies. If low income households obtain more gains from the co-benefits of the energy tax, the 'net' incidence of the policy may actually be progressive. Likewise, if wealthier households have comparatively more benefits, the 'net' incidence may be even

\footnotetext{
${ }^{1.38}$ For Brazil, a deeper assessment of an economy-wide carbon tax would require the quantification of emission coefficients from other important sources such as land use and agriculture, together with discussions on tax and discount rates, revenue recycling options and tax base.
} 
more regressive (Wang et al., 2016). Fifth, our hypothetical scenario of subsidies on ethanol prices does not consider its negative effects on both the environment and human health, which could be covered in future studies. Sixth, because we do not observe prices and quantities for all products included in the Brazilian household expenditure survey, our short-term elasticity estimates might be underestimated for several consumption groups. A suggestion for the next POF for IBGE to disclose the prices of the products used in the calculation of the consumer price index for the period in which the survey is carried out. This would improve the accuracy of future studies investigating consumer behavior patterns. 



\section{APPENDIX}

\section{A Tables and Figures}

Figure 1.1 - Evolution of GHG ( $\left.\mathrm{MtCO}_{2} \mathrm{e}\right)$ emission from energy sector (2000-2018), Brazil
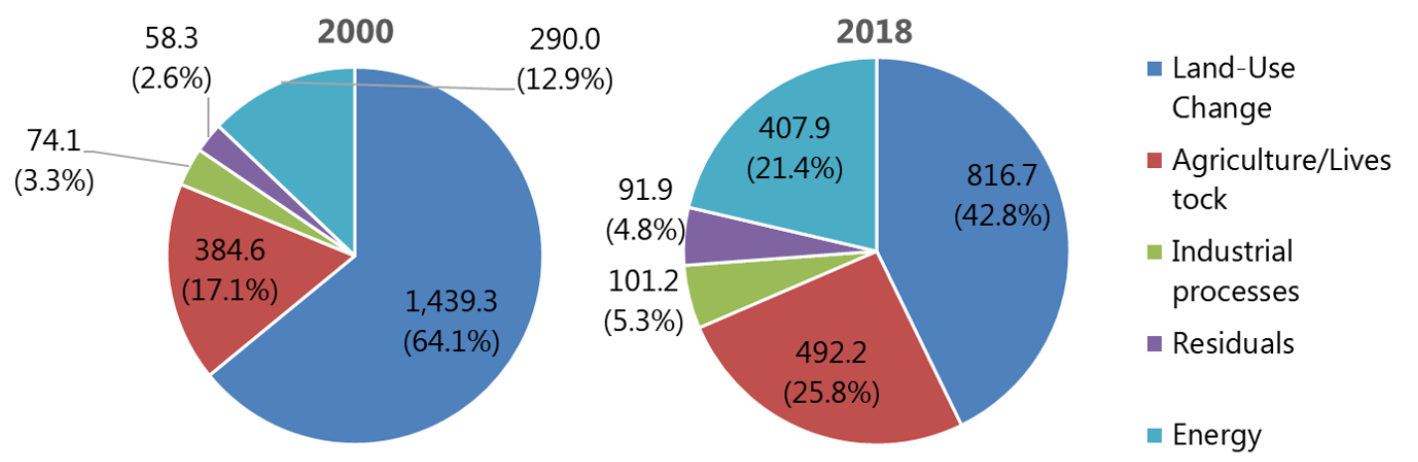

Note: This graph presents the evolution of $\mathrm{CO}_{2}$ e from energy sector according to economic activity. Data from SEEG include emissions and GHG removal, and consider CO2, CH4, N2O and HFCs converted into CO2e using GWP and GTP. 
Figure 1.2 - Overview: Energy taxation policies on consumption from 1970 to 2018

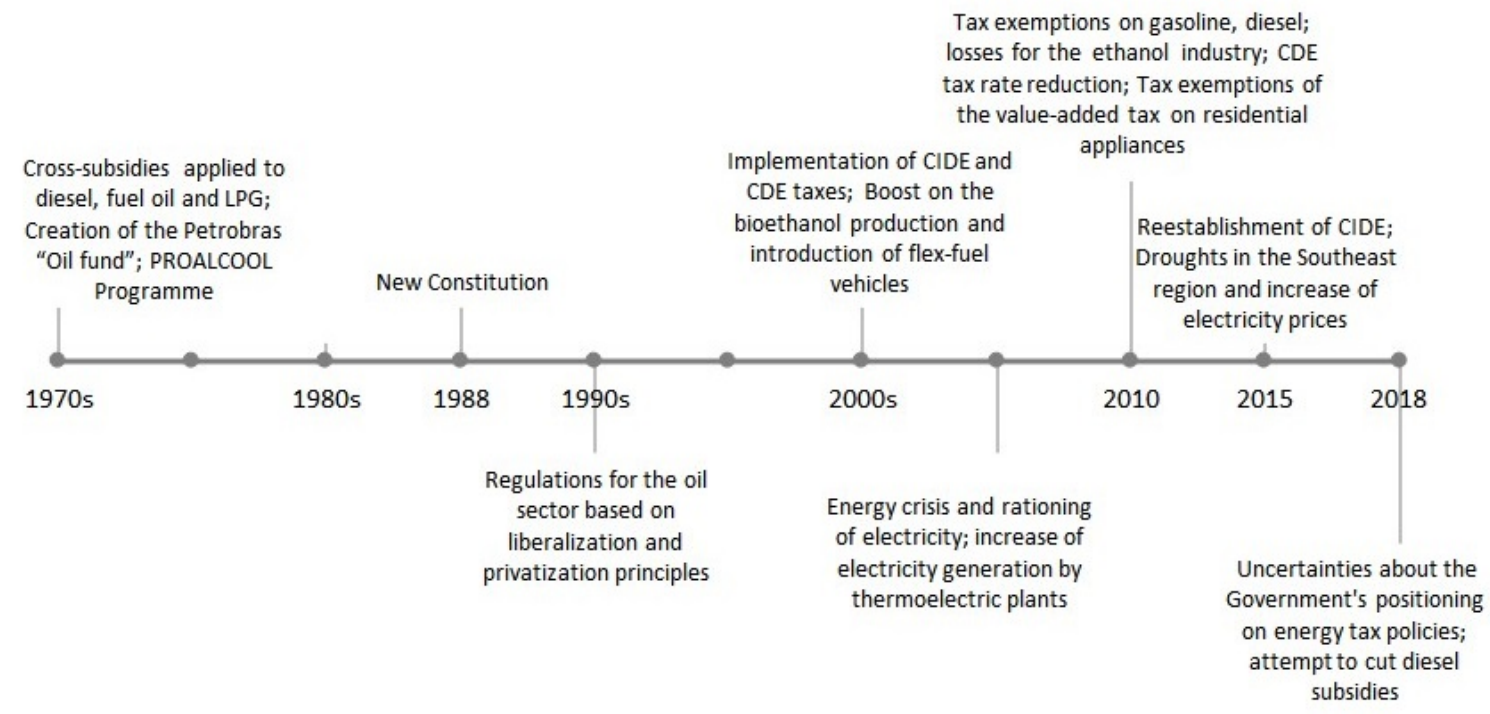

Note: This figure summarizes the main landmarks of energy taxation policies on consumption in Brazil over the past 50 years.

Table 1.1 - Compatibilization - SUTs and BEN

\begin{tabular}{lll}
\hline Code & SUTs & BEN \\
\hline \multirow{2}{*}{05801} & Mineral coal & $\begin{array}{l}\text { Steam coal } \\
\text { Coal Coke } \\
\text { Tar }\end{array}$ \\
\hline 06801 & Oil, natural gas and support services & $\begin{array}{l}\text { Natural gas } \\
\text { Other primary source }\end{array}$ \\
\hline 19912 & Gasohol & Gasoline \\
\hline 19913 & Naphtha for petrochemicals & Naphtha \\
\hline 19914 & Fuel oil & Fuel oil \\
\hline 19915 & Diesel - biodiesel & Diesel oil \\
\hline 19916 & Other oil refining products & $\begin{array}{l}\text { GLP } \\
\text { Other secondary oil }\end{array}$ \\
\hline 19921 & Ethanol and other biofuels & $\begin{array}{l}\text { Sugarcane products } \\
\text { Anhydrous and hydrated ethyl alcohol }\end{array}$ \\
\hline 02801 & Forestry and forestry products & Firewood \\
\hline 19911 & Aviation fuels & Kerosene \\
\hline 20913 & Organic chemicals & Charcoal \\
\hline 35001 & Electricity, gas and other utilities & $\begin{array}{l}\text { City and coconut gas } \\
\text { Electricity }\end{array}$ \\
\hline
\end{tabular}

Note: This table presents the compatibilization between 2009 economic sectors/goods from SUTs and energy sources from BEN, based on Montoya et al. (2014). 
Table 1.2 - Description of expenditure groups

\begin{tabular}{lll}
\hline \multicolumn{2}{c}{ Group } & \multicolumn{1}{c}{ Items } \\
\hline 1 & Food and beverages & Food, beverages, catering \\
2 & Recreation, culture and education & Privateeducation, arts, books, hotels \\
3 & Clothing and footwear & Clothes, shoes, fabrics, textiles \\
4 & Commuting and transportation & Air, water and ground transportation \\
5 & Health and hygiene & Pharmaceutical products, private health \\
6 & Energy & Electricity, gas, ethanol, diesel, charcoal \\
7 & Housing & Residential appliances, rent, water, sewage \\
8 & Other goods & Plastic, ceramic, wood and paper articles \\
9 & Other services & Public and other administrative services
\end{tabular}

Note: This table presents the 9 consumption groups used in the demand system estimation, and it covers the total household consumption basket. Residential appliances include equipment such as stoves, washing machines, refrigerators, televisions, vacuum cleaners, electric ovens, electric irons, TV, air conditioners, fans, computers, microwave ovens and clothes dryers. We are not able to split electricity from gas since these products are aggregated on the SUTs. 
Table 1.3 - Summary statistics: socioeconomic characteristics (mean/(sd))

\begin{tabular}{|c|c|c|c|}
\hline Variables & $\begin{array}{c}\text { All } \\
\text { sample }\end{array}$ & $\begin{array}{l}20 \% \\
\text { richiest }\end{array}$ & $\begin{array}{l}20 \% \\
\text { poorest }\end{array}$ \\
\hline Education - household head (years) & $\begin{array}{c}7.4 \\
(0.03)\end{array}$ & $\begin{array}{c}10.6 \\
(0.07)\end{array}$ & $\begin{array}{c}5.9 \\
(0.03)\end{array}$ \\
\hline Age - household head (years) & $\begin{array}{c}47.6 \\
(0.15)\end{array}$ & $\begin{array}{c}49.1 \\
(0.24)\end{array}$ & $\begin{array}{c}42.6 \\
(0.21)\end{array}$ \\
\hline Female headed households (\%) & $\begin{array}{c}31.5 \\
(46.4)\end{array}$ & $\begin{array}{c}25.9 \\
(43.8)\end{array}$ & $\begin{array}{c}36.9 \\
(48.2)\end{array}$ \\
\hline Bathrooms (Number) & $\begin{array}{c}1.3 \\
(0.01)\end{array}$ & $\begin{array}{c}2.8 \\
(0.02)\end{array}$ & $\begin{array}{c}1.1 \\
(0.01)\end{array}$ \\
\hline Rooms (Number) & $\begin{array}{c}3.3 \\
(0.00)\end{array}$ & $\begin{array}{c}7.5 \\
(0.02)\end{array}$ & $\begin{array}{c}3.1 \\
(0.00)\end{array}$ \\
\hline People in the household (Number) & $\begin{array}{c}3.4 \\
(1.73)\end{array}$ & $\begin{array}{c}3.5 \\
(1.50)\end{array}$ & $\begin{array}{c}3.1 \\
(1.80)\end{array}$ \\
\hline Home ownership (\%) & $\begin{array}{c}69.5 \\
(45.9)\end{array}$ & $\begin{array}{c}73.0 \\
(44.3)\end{array}$ & $\begin{array}{c}65.7 \\
(47.4)\end{array}$ \\
\hline Total earnings(USD 2019/per capita/year) & $\begin{array}{c}15,304 \\
(14,275)\end{array}$ & $\begin{array}{c}46,492 \\
(41,419)\end{array}$ & $\begin{array}{c}3,335 \\
(1,117)\end{array}$ \\
\hline Dis. income (USD 2019/per capita/year) & $\begin{array}{c}6,185 \\
(3,909)\end{array}$ & $\begin{array}{c}15,887 \\
(9,702)\end{array}$ & $\begin{array}{l}1,468 \\
(553)\end{array}$ \\
\hline Car ownership (\%) & $\begin{array}{c}27.7 \\
(44.7)\end{array}$ & $\begin{array}{c}76.3 \\
(42.5)\end{array}$ & $\begin{array}{c}5.3 \\
(22.3)\end{array}$ \\
\hline Moto ownership (\%) & $\begin{array}{c}16.2 \\
(36.8)\end{array}$ & $\begin{array}{c}20.9 \\
(40.6)\end{array}$ & $\begin{array}{c}10.0 \\
(30.0)\end{array}$ \\
\hline Electricity (\%) & $\begin{array}{c}97.0 \\
(17.0)\end{array}$ & $\begin{array}{l}99.5 \\
(6.9)\end{array}$ & $\begin{array}{c}93.4 \\
(24.8)\end{array}$ \\
\hline Residential appliances (Number) & $\begin{array}{c}8.0 \\
(4.0)\end{array}$ & $\begin{array}{l}13.0 \\
(6.0)\end{array}$ & $\begin{array}{c}5.0 \\
(2.0)\end{array}$ \\
\hline
\end{tabular}

Note: This table presents the descriptive statistics for control variables according to income-level of socioeconomic variables used in the demand system. Residential appliances include stoves, freezers, refrigerators, vacuum cleaners, electric ovens, electric irons, washing machines, color TVs, black and white TVs, sound systems, radios, air conditioners, fans, computers, microwaves, DVD player, clothes dryers and washing machines. Income deciles are constructed based on total household monetary and non-monetary income reported by POF. Monetary values were converted to USD 2019 using the average exchange rate for that year from the Central Bank of Brazil. Disp. income = disposable income. 
Table 1.4 - Price indices by group and income level (in USD 2019 values) $($ mean $/(\mathrm{sd}))$

\begin{tabular}{llccc}
\hline \multicolumn{2}{c}{ Groups } & All sample & 20\% richest & 20\% poorest \\
\hline Food/Bev. & (USD/Kg) & 9.48 & 11.22 & 8.39 \\
& & $(0.06)$ & $(0.23)$ & $(0.06)$ \\
Rec./Educ & (USD/service) & 250.46 & 428.40 & 163.14 \\
& & $(1.99)$ & $(6.80)$ & $(1.54)$ \\
Cloth./Foot & (USD/item) & 31.39 & 38.27 & 27.47 \\
& & $(0.12)$ & $(0.39)$ & $(0.15)$ \\
Com./Transp. & (USD/service) & 512.05 & 694.08 & 390.82 \\
& & $(3.58)$ & $(11.13)$ & $(3.61)$ \\
Health/Hyg. & (USD/service) & 9.94 & 14.22 & 7.48 \\
& & $(0.09)$ & $(0.37)$ & $(0.04)$ \\
Energy & (USD/KWh,L) & 15.93 & 20.55 & 12.89 \\
& & $(0.09)$ & $(0.31)$ & $(0.11)$ \\
Housing & (USD/service) & 172.41 & 242.35 & 134.76 \\
& & $(1.32)$ & $(4.57)$ & $(1.22)$ \\
Oth.goods & (USD/item) & 55.10 & 83.96 & 38.23 \\
& & $(0.63)$ & $(2.03)$ & $(0.53)$ \\
Oth.services & (USD/service) & 117.10 & 191.42 & 72.60 \\
& & $(0.92)$ & $(2.94)$ & $(0.98)$ \\
\hline
\end{tabular}

Note: This table presents price indixes by group and income level, converted to USD 2019 using the average exchange rate for that year from the Central Bank of Brazil. They should be interpreted as relative price indexes. Income deciles are constructed based on total household monetary and non-monetary income reported by POF. Other goods contain rubber, plastic, ceramic goods, non-metallic minerals, inorganic chemicals. Other services include development of systems and other information services, private and public administrative services. 
Table 1.5 - Positive consumption and expenditure shares by group/ income level $(\%)($ mean $/(\mathrm{sd}))$

\begin{tabular}{|c|c|c|c|c|c|c|}
\hline \multirow{2}{*}{ Groups } & \multicolumn{3}{|c|}{$\%$ of positive consumption } & \multicolumn{3}{|c|}{ Budget share } \\
\hline & $\begin{array}{c}\text { All } \\
\text { sample }\end{array}$ & $\begin{array}{l}20 \% \\
\text { richiest }\end{array}$ & $\begin{array}{l}20 \% \\
\text { poorest }\end{array}$ & $\begin{array}{c}\text { All } \\
\text { sample }\end{array}$ & $\begin{array}{l}20 \% \\
\text { richiest }\end{array}$ & $\begin{array}{l}20 \% \\
\text { poorest }\end{array}$ \\
\hline Food/Bev. & $89 \%$ & $80 \%$ & $94 \%$ & $\begin{array}{c}25.8 \% \\
(23.0 \%)\end{array}$ & $\begin{array}{c}15.7 \% \\
(15.1 \%)\end{array}$ & $\begin{array}{c}37.0 \% \\
(26.7 \%)\end{array}$ \\
\hline Rec./Educ. & $20 \%$ & $40 \%$ & $11 \%$ & $\begin{array}{c}4.1 \% \\
(2.4 \%)\end{array}$ & $\begin{array}{l}10.5 \% \\
(8.5 \%)\end{array}$ & $\begin{array}{c}1.0 \% \\
(0.9 \%)\end{array}$ \\
\hline Cloth./Foot. & $77 \%$ & $79 \%$ & $63 \%$ & $\begin{array}{c}3.8 \% \\
(3.7 \%)\end{array}$ & $\begin{array}{c}3.2 \% \\
(1.8 \%)\end{array}$ & $\begin{array}{c}3.1 \% \\
(2.4 \%)\end{array}$ \\
\hline Com./Transp. & $37 \%$ & $38 \%$ & $21 \%$ & $\begin{array}{c}7.3 \% \\
(6.4 \%)\end{array}$ & $\begin{array}{c}12.9 \% \\
(12.1 \%)\end{array}$ & $\begin{array}{c}3.7 \% \\
(3.4 \%)\end{array}$ \\
\hline Health/Hyg. & $18 \%$ & $46 \%$ & $17 \%$ & $\begin{array}{c}9.5 \% \\
(9.4 \%)\end{array}$ & $\begin{array}{c}7.6 \% \\
(5.9 \%)\end{array}$ & $\begin{array}{c}11.8 \% \\
(10.0 \%)\end{array}$ \\
\hline Energy & $65 \%$ & $78 \%$ & $41 \%$ & $\begin{array}{l}14.4 \% \\
(9.1 \%)\end{array}$ & $\begin{array}{c}21.7 \% \\
(19.5 \%)\end{array}$ & $\begin{array}{c}9.3 \% \\
(6.8 \%)\end{array}$ \\
\hline Housing & $85 \%$ & $91 \%$ & $79 \%$ & $\begin{array}{c}14.8 \% \\
(14.2 \%)\end{array}$ & $\begin{array}{c}16.3 \% \\
(13.0 \%)\end{array}$ & $\begin{array}{l}12.8 \% \\
(5.8 \%)\end{array}$ \\
\hline Oth.goods & $76 \%$ & $47 \%$ & $84 \%$ & $\begin{array}{c}12.3 \% \\
(11.7 \%)\end{array}$ & $\begin{array}{c}6.0 \% \\
(3.0 \%)\end{array}$ & $\begin{array}{c}18.0 \% \\
(15.0 \%)\end{array}$ \\
\hline Oth.services & $30 \%$ & $42 \%$ & $19 \%$ & $\begin{array}{c}3.2 \% \\
(2.9 \%)\end{array}$ & $\begin{array}{c}6.1 \% \\
(5.9 \%)\end{array}$ & $\begin{array}{c}1.3 \% \\
(0.6 \%)\end{array}$ \\
\hline
\end{tabular}

Note: This table shows the descriptive statistics of budget shares (in 2019 USD), positive consumption for each of the nine groups and income levels. Income deciles are constructed based on total household monetary and non-monetary income reported by POF. Other goods contain rubber, plastic, ceramic goods, non-metallic minerals, inorganic chemicals. Other services include development of systems and other information services, private and public administrative services.

Table 1.6 - Expenditure share of energy goods by income level (mean/(sd)

\begin{tabular}{lccc}
\hline & All sample & $20 \%$ richest & $20 \%$ pooresthline \\
\hline Charcoal & $0.1 \%$ & $0.3 \%$ & $0.2 \%$ \\
& $(0.1 \%)$ & $(0.9 \%)$ & $(0.2 \%)$ \\
Diesel & $2.8 \%$ & $4.1 \%$ & $1.1 \%$ \\
& $(2.1 \%)$ & $(0.0 \%)$ & $(0.0 \%)$ \\
Electricity and Gas & $61.9 \%$ & $40.5 \%$ & $73.4 \%$ \\
& $(20.2 \%)$ & $(20.5 \%)$ & $(11.2 \%)$ \\
Ethanol & $3.7 \%$ & $5.2 \%$ & $1.7 \%$ \\
& $(10.4 \%)$ & $(3.2 \%)$ & $(0.9 \%)$ \\
Gasoline & $32.7 \%$ & $50.8 \%$ & $23.2 \%$ \\
& $(30.7 \%)$ & $(18.1 \%)$ & $(9.6 \%)$ \\
\hline
\end{tabular}

Note: This table shows the expenditure share, in \%, of goods included in group 6 according to income-level. Income deciles are constructed based on total household monetary and non-monetary income reported by POF. We are not able to split electricity from gas since these products are aggregated in the SUTs. 
Table 1.7 - Description of policy scenarios

\begin{tabular}{cl}
\hline Scenarios & Description \\
\hline Implemented & \\
1 & $10 \%$ subsidy on diesel \\
2 & $20 \%$ subsidy on electricity and gas \\
3 & $10 \%$ tax on gasoline \\
4 & $10 \%$ subsidy on residential appliances \\
Simulations & $10 \%$ tax on diesel \\
5 & $10 \%$ subsidy on ethanol \\
6 & $10 \%$ tax on gasoline $+10 \%$ subsidy on ethanol \\
7 & $10 \%$ tax on gasoline and diesel $+10 \%$ subsidy on ethanol \\
9 & $10 \%$ subsidy on res. appliances $+10 \%$ tax on electricity and gas \\
\hline
\end{tabular}

Note: This table describes and welfare across income-level groups. As a reference, we use de facto tax and subsidy rates implemented on different household energy goods (transport fuels, electricity and residential appliances), as well as alternative and more environmentally-friendly tax policies.

Table 1.8 - Total $\mathrm{CO}_{2}$ e Emission $\left(\mathrm{tCO}_{2} \mathrm{e} / \mathrm{hh} /\right.$ year, in 2019 values)

\begin{tabular}{lccc}
\hline Groups & Average & 20\% richest & 20\% poorest \\
\hline Food/beverages & 3.3 & 6.0 & 0.4 \\
Recreation/education & 1.6 & 3.1 & 0.0 \\
Clothing/footwear & 0.3 & 0.8 & 0.1 \\
Commuting/transportation & 2.0 & 8.0 & 0.1 \\
Health/hygiene & 0.6 & 1.8 & 0.2 \\
Energy & 1.2 & 3.0 & 0.3 \\
Housing & 0.6 & 1.3 & 0.3 \\
Other goods & 0.6 & 2.0 & 0.3 \\
Other services & 0.2 & 0.1 & 0.0 \\
\hline Total & 10.5 & 26.1 & 1.7 \\
\hline
\end{tabular}

Note: Note: This Table presents total $\mathrm{CO}_{2} \mathrm{e}$ emissions by income level, obtained by multiplying the emission coefficients from Table 1.11 with expenditures from Table 1.5. Income deciles are constructed based on total household monetary and non-monetary income reported by POF. Monetary values were converted to USD 2019 using the average exchange rate for that year from the Central Bank of Brazil. 
Table $1.9-\mathrm{CO}_{2} \mathrm{e}$ emission coefficients $\left(\mathrm{tCO}_{2} \mathrm{e} / \mathrm{USD}\right.$ million, 2019) from intermediate consumption and final demand for each good/service in the economy (2010)

\begin{tabular}{|c|c|c|c|}
\hline Group & Good/service (IO) & Int. Cons. & Final Demand \\
\hline 4 & Cargo transportation & 3,778 & 8,044 \\
\hline 4 & Passenger transportation & 3,672 & 7,821 \\
\hline 4 & Air transportation & 2,011 & 3,821 \\
\hline 4 & Water transportation & 1,760 & 3,813 \\
\hline 8 & Wood products, except furniture & 1,097 & 3,072 \\
\hline 8 & Paper, paperboard and paper articles & 1,093 & 3,066 \\
\hline 7 & Printing services & 1,020 & 2,880 \\
\hline 8 & Cement, plaster & 646 & 2,067 \\
\hline 8 & Glass, ceramics and others & 618 & 2,001 \\
\hline 8 & Metal products, excl. machinery and equipment & 397 & 1,897 \\
\hline 1 & Pork & 46 & 1,254 \\
\hline 1 & Processed fish & 45 & 1,253 \\
\hline 2 & Tabacco products & 47 & 1,253 \\
\hline 7 & Animal feed & 46 & 1,251 \\
\hline 1 & Other dairy Products & 54 & 1,249 \\
\hline 1 & Coffee (processed) & 48 & 1,247 \\
\hline 1 & Beef and other meat products & 46 & 1,247 \\
\hline 1 & Drinks & 46 & 1,247 \\
\hline 1 & Canned fruits, vegetables and fruit juices & 46 & 1,246 \\
\hline 8 & Non-metallic Minerals & 346 & 1,230 \\
\hline 6 & coal & 334 & 1,201 \\
\hline 1 & Sugar & 58 & 1,200 \\
\hline 1 & Products derived from wheat, manioc and corn & 69 & 1,199 \\
\hline 5 & Perfumery, soaps and cleaning products & 176 & 1,196 \\
\hline 1 & Sterilized and pasteurized milk & 42 & 1,190 \\
\hline 1 & Processed rice and products & 65 & 1,188 \\
\hline 7 & Advertising and other technical services & 419 & 1,184 \\
\hline 1 & Poultry & 41 & 1,176 \\
\hline 1 & Oils and fats, vegetable and animal & 43 & 1,176 \\
\hline 5 & Other products & 158 & 1,164 \\
\hline 8 & Inorganic chemicals & 161 & 1,149 \\
\hline 8 & Paints, varnishes, enamels and lacquers & 154 & 1,142 \\
\hline 8 & Plastic articles & 149 & 1,132 \\
\hline 8 & Detergents and household cleaning products & 140 & 1,118 \\
\hline
\end{tabular}

Note: This table presents the $\mathrm{CO}_{2} \mathrm{e}$ coefficient estimates, in 2019 values, based on data from SUTs (2010) and the Brazilian Energy Mix (2010). Monetary values were converted to USD 2019 using the average exchange rate for that year from the Central Bank of Brazil. 
Table $1.10-\mathrm{CO}_{2} \mathrm{e}$ emission coefficients $\left(\mathrm{tCO}_{2} \mathrm{e} / \mathrm{USD}\right.$ million, 2019) from intermediate consumption and final demand for each good/service in the economy (2010) (cont.)

\begin{tabular}{|c|c|c|c|}
\hline Group & Good/service (IO) & Int. Cons. & Final Demand \\
\hline 8 & Rubber articles & 138 & 1,109 \\
\hline 8 & Detergents and household cleaning products & 140 & 1,118 \\
\hline 8 & Rubber articles & 138 & 1,109 \\
\hline 1 & Other food products & 41 & 1,107 \\
\hline 8 & Forestry & 353 & 1,080 \\
\hline 5 & Pharmaceutical products & 131 & 1,063 \\
\hline 1 & Sugarcane & 343 & 1,058 \\
\hline 1 & Fisheries & 343 & 1,058 \\
\hline 1 & Soybeans & 343 & 1,058 \\
\hline 1 & Poultry and eggs & 343 & 1,058 \\
\hline 1 & Citrus fruits & 343 & 1,058 \\
\hline 1 & Swine products & 343 & 1,058 \\
\hline 1 & Milk (cows and other animals) & 342 & 1,058 \\
\hline 1 & Bovine animals & 342 & 1,058 \\
\hline 1 & Other (permanent) agriculture & 342 & 1,056 \\
\hline 1 & Other (temporary) & 341 & 1,054 \\
\hline 1 & Corn & 340 & 1,050 \\
\hline 1 & Rice & 335 & 1,038 \\
\hline 6 & Ethanol and other biofuels & 103 & 1,009 \\
\hline 8 & Goods of other enterprises & 61 & 867 \\
\hline 9 & Other machines and mechanical equipment & 53 & 858 \\
\hline 6 & Electricity, gas and other utilities & 140 & 824 \\
\hline 6 & Gasohol & 141 & 823 \\
\hline 6 & Diesel - biodiesel & 141 & 823 \\
\hline 8 & Other refined petroleum products & 136 & 808 \\
\hline 4 & Aircraft, boats and other transport equipment & 33 & 806 \\
\hline 7 & Electrical machinery and equipment & 31 & 803 \\
\hline 4 & Trucks and buses & 30 & 799 \\
\hline 9 & Equip. for measurement, testing & 31 & 799 \\
\hline 7 & Home appliances & 32 & 798 \\
\hline 7 & Furniture & 32 & 795 \\
\hline 7 & Electronic material and communications equip. & 28 & 795 \\
\hline 4 & Automobiles, trucks and commercial vehicles & 27 & 793 \\
\hline 9 & Office machines and equipment & 29 & 790 \\
\hline
\end{tabular}

Note: This table presents the $\mathrm{CO} 2_{2}$ e coefficient estimates, in 2019 values, build based on data from SUTs (2010) and the Brazilian Energy Mix (2010). Monetary values were converted to USD 2019 using the average exchange rate for that year from the Central Bank of Brazil. 
Table $1.11-\mathrm{CO}_{2}$ e emission coefficients $\left(\mathrm{tCO}_{2} \mathrm{e} / \mathrm{USD}\right.$ million, 2019) from intermediate consumption and final demand for each good/service in the economy (2010) (cont.)

\begin{tabular}{clrr}
\hline & & & \\
Group & \multicolumn{1}{c}{ Good/service (IO) } & Int. Cons. & Final Demand \\
\hline 3 & Yarn and textile fibers & 62 & 692 \\
3 & Textiles for household use and others & 41 & 679 \\
3 & Textiles and leather Products & 37 & 666 \\
3 & Footwear and leather goods & 36 & 661 \\
3 & Clothing articles and accessories & 34 & 651 \\
7 & Rent and real estate services & 89 & 588 \\
4 & Warehousing and others & 95 & 531 \\
7 & Wholesale trade and sale, except motor vehicles & 9 & 376 \\
7 & Maintenance of computers, telephones & 5 & 363 \\
9 & Other administrative services & 9 & 361 \\
7 & Intellectual Property Assets & 6 & 360 \\
4 & Trade and repair of vehicles & 5 & 359 \\
2 & Accommodation services in hotels and similar & 7 & 354 \\
7 & Courier and other delivery services & 5 & 353 \\
7 & Employer organizations, trade and union & 5 & 353 \\
7 & Condominium and building management & 5 & 353 \\
7 & Surveillance, security and investigation services & 5 & 353 \\
7 & Domestic services & 5 & 353 \\
7 & Personal services & 5 & 353 \\
7 & Telecommunications and others & 5 & 353 \\
2 & Film, music, radio & 5 & 353 \\
7 & Financial services, insurance & 5 & 353 \\
2 & Food services & 5 & 353 \\
9 & Systems dev. and IT services & 5 & 352 \\
2 & Books, newspapers and magazines & 5 & 352 \\
2 & Arts, culture and recreation services & 5 & 350 \\
7 & Architectural and engineering services & 5 & 350 \\
5 & Private health & 5 & 349 \\
7 & Legal services, accounting & 5 & 348 \\
2 & Private education & 5 & 347 \\
9 & Public administration & 12 & 192 \\
7 & Water, sewage & 5 & 192 \\
\hline
\end{tabular}

Note: This table presents the $\mathrm{CO} 22_{2}$ e coefficient estimates, in 2019 values, based on data from SUTs (2010) and the Brazilian Energy Mix (2010). Monetary values were converted to USD 2019 using the average exchange rate for that year from the Central Bank of Brazil. 


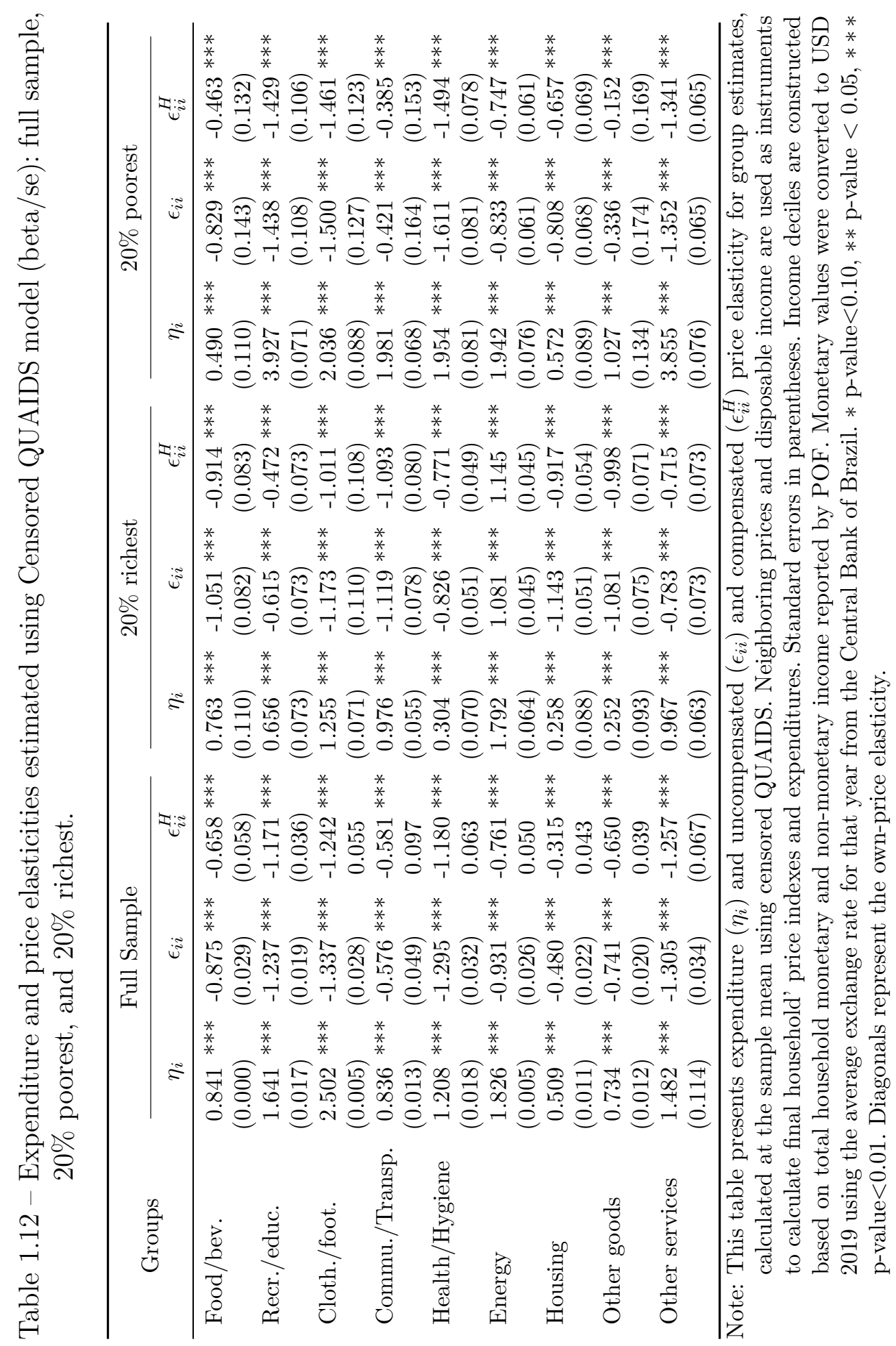




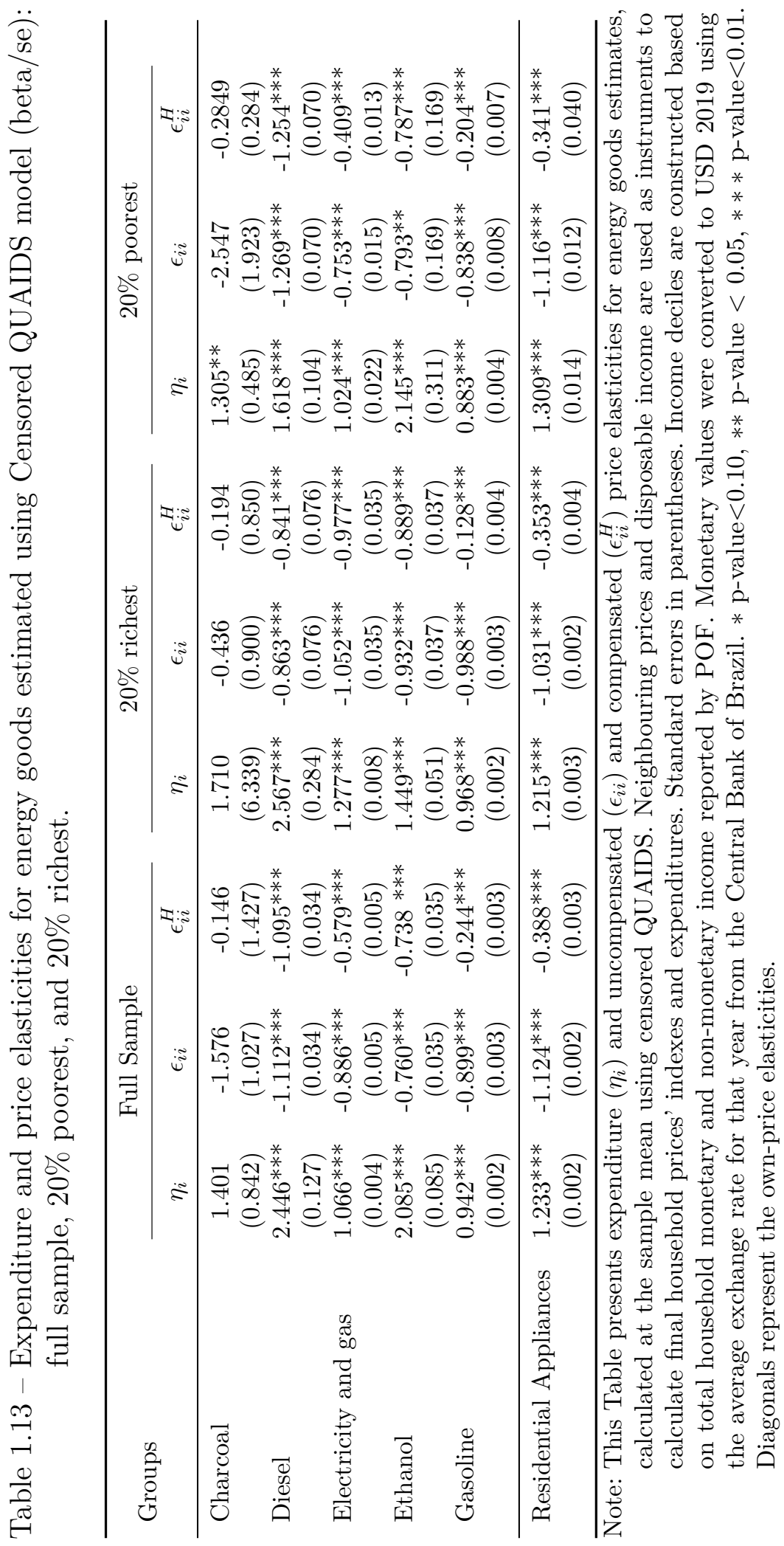




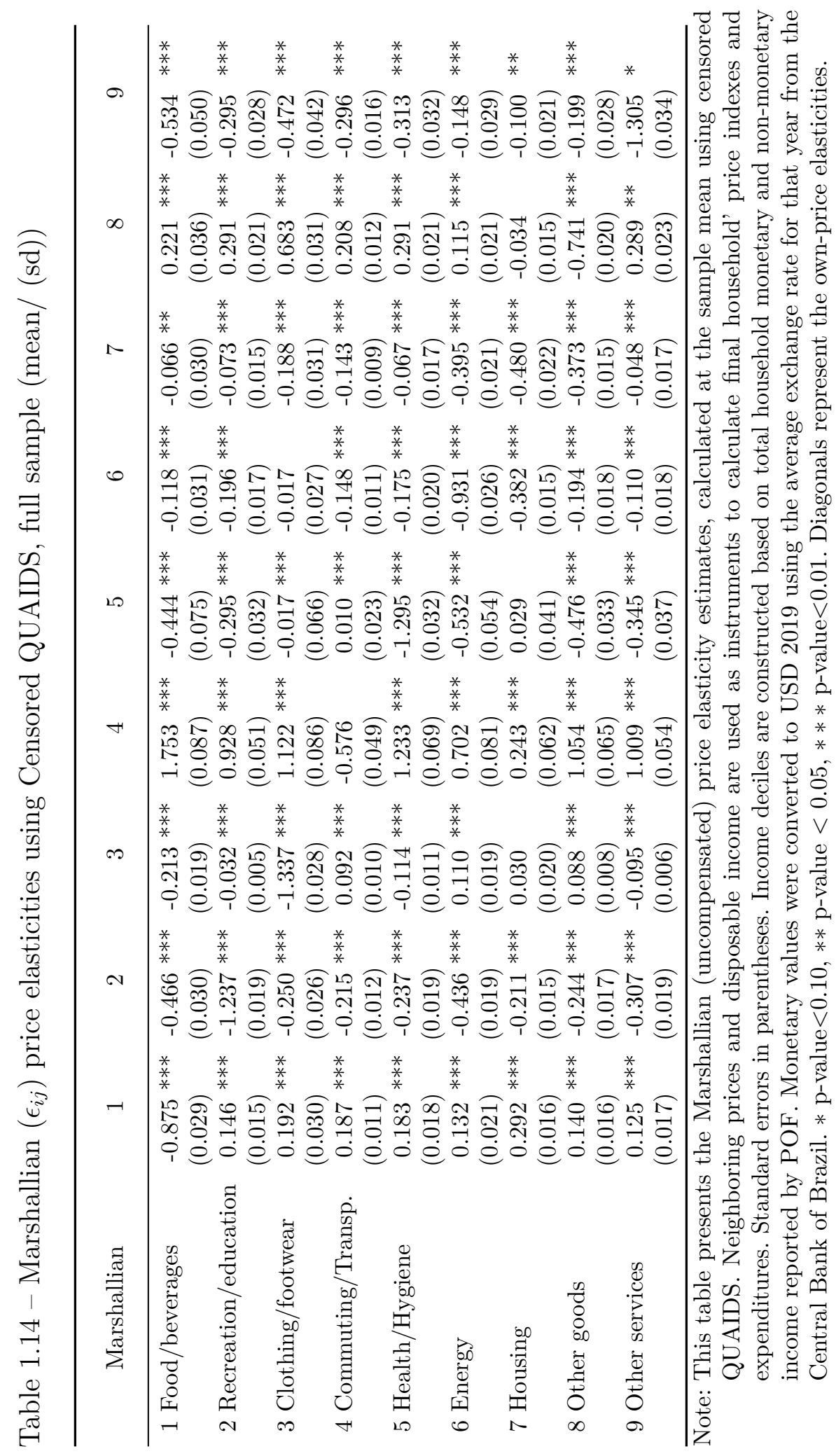




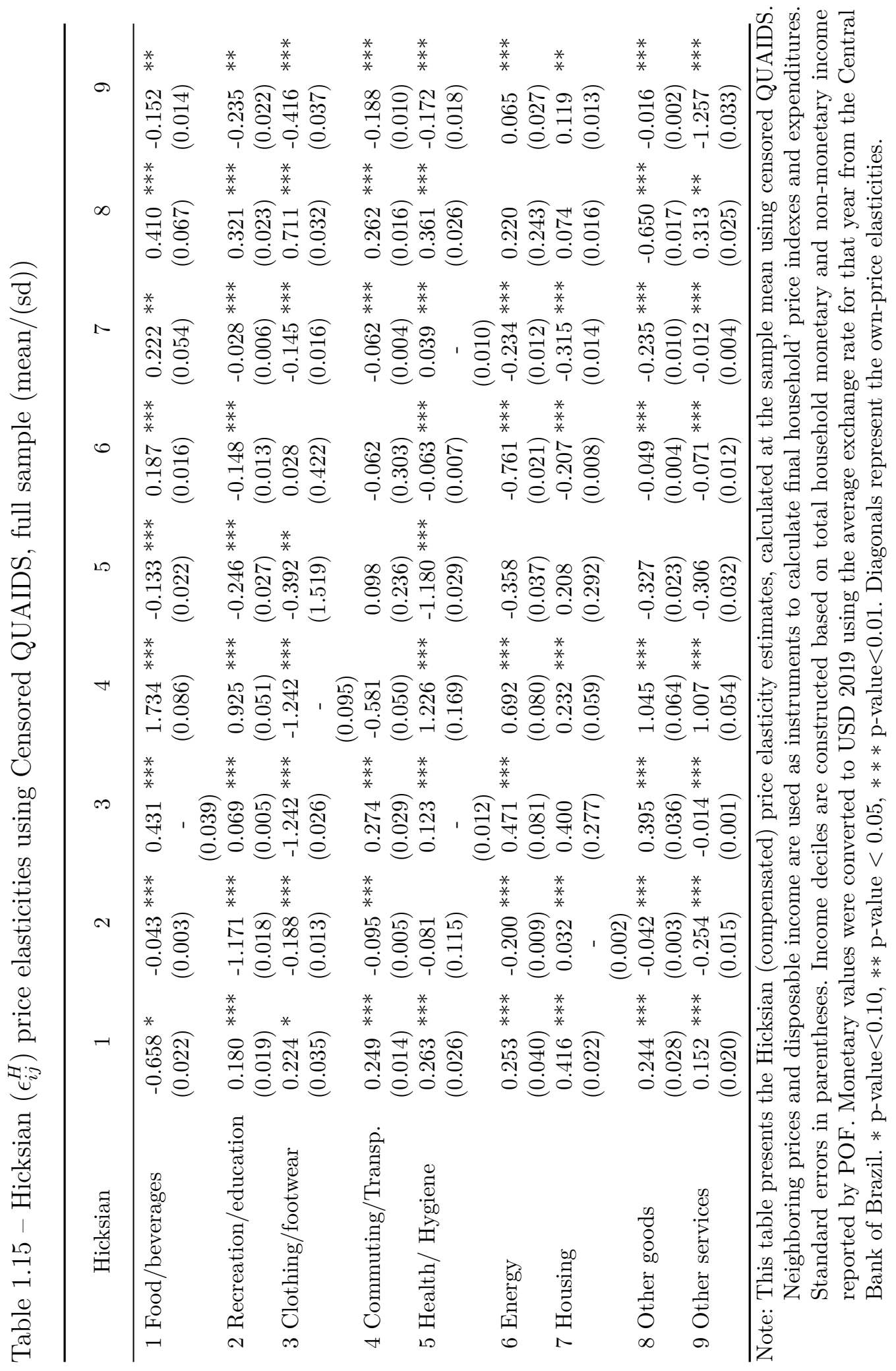




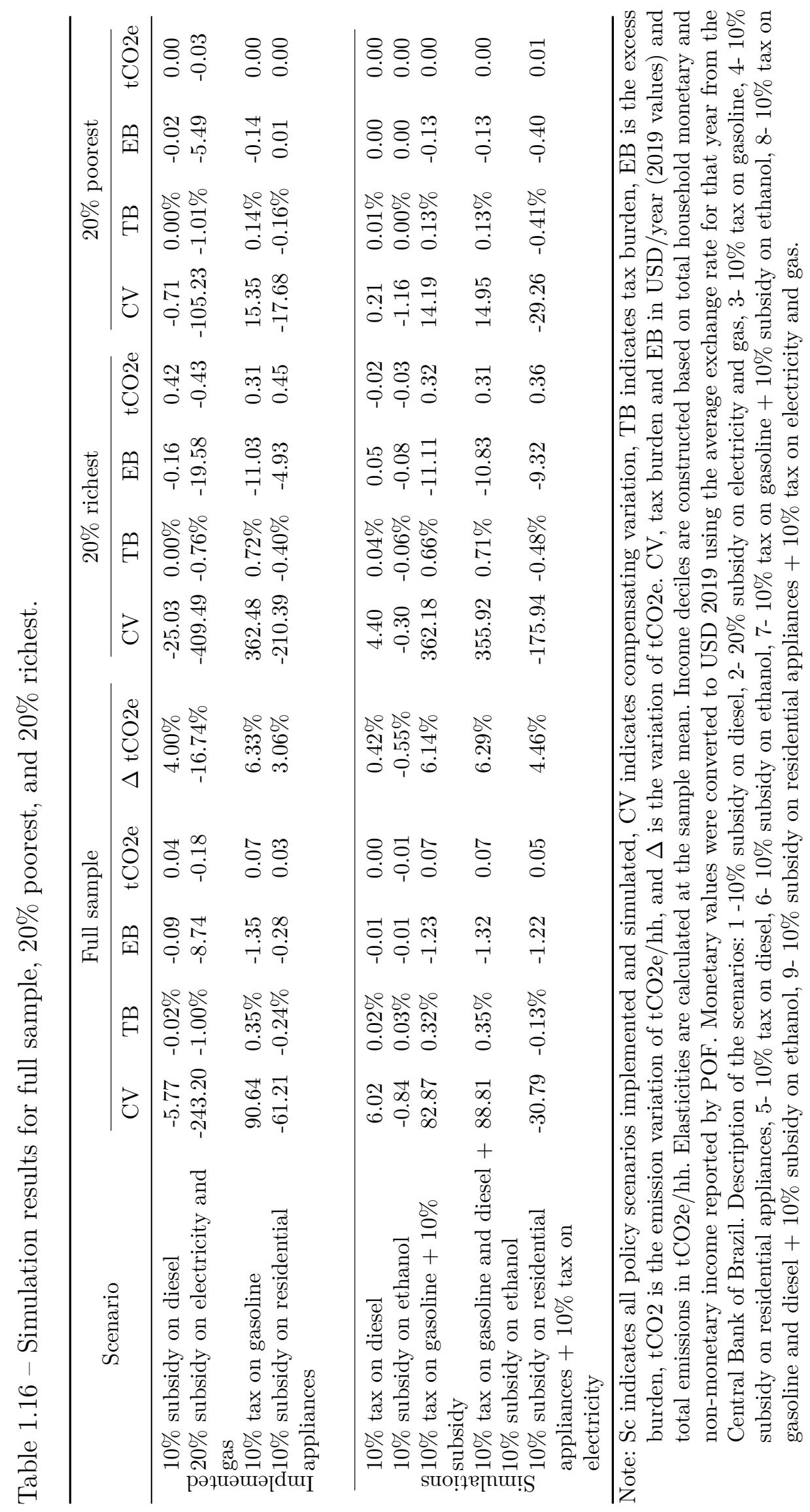




\section{B Appendix B - Price correction of censored QUAIDS}

To account for differences in quality and packaging, Cox and Wohlgenant (1986) considered that quality effects are expressed as deviations of unit values from regional or seasonal means. Thus, they regressed the mean-deviated unit values on household characteristics to exclude the quality effects from unit values. In order to adjust this method to the assumption of common market prices $^{1.39}$, as well as to overcome the error measurement issue, we follow Lazaridis (2003) and extend the controls used by Cox and Wohlgenant (1986):

$$
U V_{i}-U \bar{V}_{n}=\sum_{l}^{L} \beta_{i l} Z_{l}+\sum_{c}^{C} \omega_{i c} D_{i c}+\sum_{m}^{M} \theta_{i m} V_{i m}+\sum_{s}^{S} \sum_{m}^{M} \delta_{i s m} U_{i s} V_{i m}+\epsilon_{i}
$$

in which $U V_{i}$ is the unit value (total expenditure divided by consumed quantity) of good $i, U \bar{V}_{n}$ represents its corresponding cluster mean, $Z$ is a vector of household characteristics, $D_{i c}$ is a dummy for cluster, $V_{i m}$ represent a dummy variable for group $m$ and $L, C$ and $M$ are the sets of household characteristics, cluster and group indexes, respectively.

The quality-adjusted prices for each item of the group food and beverages, $p_{i}$, are generated by adding the mean unit value to the residual derived from Equation 1.15:

$$
p_{i}=U \bar{V}_{n}+\hat{\epsilon}_{i}
$$

${ }^{1.39}$ See footnote 1.33 . 


\section{Chapter 2}

\section{WINNERS AND LOSERS: THE DISTRIBUTIONAL IMPACTS OF A CARBON TAX IN BRAZIL}

\subsection{Introduction}

Since 2005, reductions in land-use and forestry emissions have contributed to the expressive decrease of the overall GHG emissions in Brazil. However, the steadily decline of the country's share of renewable sources in the energy mix boosted energy-related emissions: currently, the sector emits 30\% more compared to 2005 levels (BRASIL, 2020). Energy emissions are projected to rise given the recent oil discoveries in the offshore fields and the near exhaustion of the country's environmentally feasible hydropower potential.

Environmental economists have been advocating for carbon taxes as the fastest and most efficient instrument to curb emissions from fossil fuels ${ }^{2.1}$. The idea is to transfer the environmental costs paid by third parties (society) to those that are responsible for them (polluters) ${ }^{2.2}$. Carbon tax might also have the potential to generate dividends (Nordhaus, 1993; Pearce, 1991; Goulder, 1995; Fullerton and Metcalf, 1997): the reduction of the environmental damage ("first dividend") and the potential to use its revenue to reduce other distortionary taxes ("second dividend"), such as taxes on labor and capital ${ }^{2.3}$, or to support funding investments on cleaner power generation, smart vehicles, and improvements in energy efficiency, keeping the government budgetary position and the overall tax burden unchanged (also know as "revenue neutrality") 2.4 .

\footnotetext{
${ }^{2.1}$ Compared to other carbon pricing mechanisms, carbon taxes are also considered a relatively simple instrument to impose on emitters, particularly in settings with a large number of small emission sources - such as transportation - as it lowers transaction costs (Carattini et al., 2018).

${ }^{2.2}$ In 2019, 57 carbon pricing schemes, such as carbon taxes or cap-and-trade systems, had been established or planned, covering $20 \%$ of the global GHG emissions (Ramstein et al., 2019).

${ }^{2.3}$ Goulder (1995) defined the two types of double dividends: i) weak - which states that recycling environmental tax revenues through lowering distortionary taxes leads to cost savings compared to the case where revenues are returned via lump-sum transfers and ii) strong - where a revenue-neutral substitution of a green tax for typical or representative distortionary taxes produces zero or negative welfare gross cost.

${ }^{2.4}$ Globally, an estimated $4 \%$ of carbon tax revenues have been used to lower other taxes, $28 \%$ for
} 
Since it first implementation in the $1990 \mathrm{~s}^{2.5}$, few underdeveloped and developing countries have implemented carbon taxation. Despite stating in Brazil's National Policy on Climate Change (PNMC) $)^{2.6}$ the possibility of adopting fiscal and tax measures to reduce anthropogenic GHG emissions, the country has used very little taxation (and sometimes subsidies) to penalize activities with negative environmental externalities: in $2017,94 \%$ of the country's emissions came from non-taxed polluting activities, the largest percentage in the world (OECD and Development, 2018) $)^{2.7,2.8}$.Benefits to oil and gas producers include special tax incentives for infrastructure development in various regions, as well as a special tax regime for equipment used in the exploration and development of hydrocarbons, and exemptions for coal used in electricity generation. This incipient uptake and acceptability of carbon taxes as a potential policy in developing settings can be linked to concerns about equity effects: critics of the double dividend existence (Fullerton and Metcalf, 1997; Babiker et al., 2003) state that, under certain circumstances, a shift to environmental taxes may increase the burden of the tax system. Therefore, distributional burdens of a carbon tax among different classes of households or production factors in a particular country needs to be assessed, not assumed (Bowen, 2015; Fullerton, 2011; Fullerton and Muehlegger, 2019).

Since a comprehensive tax system reform is a top-priority of the current Brazilian

general funds, and $15 \%$ for environmental mitigation spending (IMF, 2019).

${ }^{2.5}$ Carbon taxation was first implemented in Finland, Poland, Sweden, Norway, Denmark, Latvia and Slovenia in the 1990s. Other countries/provinces have been recently adopted this instrument, such as Estonia (2000), Switzerland (2008), British Columbia (2008), Ireland (2010), Iceland (2010), Japan (2012), France (2014), Mexico (2014), Portugal (2015), Argentina and Chile (2018), Canada (Federal Carbon Price) (2019) and South Africa (2019), with a wide range of tax rates, coverages, exemptions and revenue recycling schemes. For a complete description of current price schemes, see Ramstein et al. (2019).

${ }^{2.6}$ The PNMC is the regulatory framework that guides the government under the climate change institutional arrangement since 2009, being promulgated through Law 12,187 of 29 December 2009.

${ }^{2.7}$ The Brazilian government offers a range of tax and budgetary subsidies for fossil fuel production, which amounted to R $\$ 11.6$ billion (USD 4.9 billion) in 2015 (Nuaimy-Barker, 2015).

${ }^{2.8}$ At the federal level, the only Brazilian tax that seems to have an environmental purpose is CIDE-Fuels, implemented in 2011. However, CIDE-Fuels is far from being a carbon tax because i) it applies only on gasoline and diesel, and ii) its revenue has been managed to stabilize fuel prices or to subsidize fossil fuels and finance transportation infrastructure programs, rather than discouraging fossil fuel consumption. According to the government estimates, the current rate of $\mathrm{R} \$ 100.00 / \mathrm{m}^{3}$ and $\mathrm{R} \$ 50.00 / \mathrm{m}^{3}$ levied on gasoline and diesel are equivalent to an implicit carbon tax of USD $13.70 / \mathrm{tCO}_{2} \mathrm{e}$ and USD $5.90 / \mathrm{tCO}_{2} \mathrm{e}$, respectively, rates considerably below the range of USD $40 / \mathrm{tCO}_{2}$ e to USD $80 / \mathrm{tCO}_{2}$ e needed to be consistent with the Paris Agreement. Nonetheless, better examples are found at the state and municipal levels, such as the Ecological Sales Tax (ICMS Ecológico or ICMS-E). It aims to reduce the economic gains from deforestation and encourage environmental preservation by distributing the revenues obtained from the sales of goods and services according to the reduction in deforestation and percentage of area occupied by protected areas, indigenous lands and quilombolas - traditional communities composed of the descendants of runaway slaves. 
government and that a concrete proposal is still not defined, it is critical to shed light on potential distributional effects of an economy-wide carbon tax given the the country's historical tax burden and complex taxation structure. In this paper, we address this point by focusing on welfare and emissions outcomes of a hypothetical carbon tax on goods and services consumed by Brazilian households. To analyze the carbon tax effects, we use a top-down approach linking macro and micro models: first, direct and indirect GHG emissions coefficients from fossil energy-related fuels burned are calculated to all household basket' goods using a hybrid input-output model (I-O); second, household consumption patterns across different income-levels are identified using a system of demand equations, circumventing the zero-expenditure and under-declaration problems through a censored model with instruments for expenditures and prices; and third, the distributional impact is examined by looking at the tax burden relative to annual expenditures and changes in GHG emissions for richest and poorest households, using tax rates consistent with the Paris Agreement (USD 40/tCO $\mathrm{CO}_{2} \mathrm{e}$ and USD $80 / \mathrm{tCO}_{2} \mathrm{e}$ ). Taking into account the complexities of the Brazilian tax-system and the double dividend hypothesis, we analyze a revenue-neutral carbon tax considering a lump-sum rebate, in order to prevent an increase of the tax burden. Sensitivity analysis is also conducted with narrower tax bases depending on the carbon content of goods/products.

Our results indicate the first-dividend could be observed if an economy-wide carbon tax is implemented, as it is effective in reducing emissions by up to $4.2 \%$. However, this instrument imposes higher welfare losses on low-income households $(0.06 \%$ and $0.10 \%$ in relation to total expenditures for richest and poorest house-holds, respectively). Narrowing the tax base only on products and services with high carbon emissions might reduce the regressiveness of the carbon tax. Therefore, our findings suggest that compensation mechanisms are critical and need to be considered when designing a carbon tax, specially in the context of a highly complex tax-system ${ }^{2.9}$.

\footnotetext{
${ }^{2.9}$ The empirical literature on the distributional impacts of carbon taxation indicates ambiguous results. Many studies have found an overall tendency for regressive impacts, especially in developed countries such as Denmark (Wier et al., 2005), Sweden (Brännlund and Nordström, 2004), Netherlands (Kerkhof et al., 2008), France (Bureau, 2011), United States (Grainger and Kolstad, 2010; Fullerton, 2011) and United Kingdom (Feng et al., 2010). However, developing countries have shown an inconsistent picture, with a tendency towards proportional or progressive impacts (Wang et al., 2016; Ohlendorf et al., 2018). In this sense, these studies also show that recycling the carbon tax revenue either through a lump sum or direct transfers/subsidies could help alleviate the potential regressivity of a carbon tax or even convert it to a progressive carbon tax. Nevertheless, progressive impacts have also been found in developed settings such as Italy (Tiezzi, 2005) and British Columbia (Beck et al., 2015). Specifically for Brazil, findings are also mixed: Magalhães et al. (2013), Freitas et al. (2016) found that, despite being efficient in terms of emission reduction, the taxation is regressive. Estimates from Grottera et al. (2017), however, suggested progressive effects.
} 
We contribute to the empirical literature by using a more flexible approach that allows an in-depth understanding of substitution patterns between carbon intensive and non-intensive goods and services, extending the studies from Grottera et al. (2017), Magalhães et al. (2013), Freitas et al. (2016), as this is one of the few assessments of carbon tax incidence considering the total household consumption basket. In addition, our findings could subsidize the current political debate around the consequences of carbon pricing instruments in the country. Beyond the tax reform discussions, Brazil's Nationally Determined Contribution (NDC) is expected to be revised this year 2.10 and, unlike other countries ${ }^{2.11}$, it did not present in the document any prospect of participation in an international carbon market or carbon tax as mechanisms to achieve its mitigation targets ${ }^{2.12}$, despite having its regulatory framework allowing for it. Therefore, the government might consider the implementation of market instruments to meet the country's mitigation targets and reduce overall mitigation costs.

The paper is organized as follows: first, we present the literature review of the distributional effects of a carbon tax in Section 2.2; the empirical strategy and description of the data sources used in this study are presented in Section 2.3; in Section 2.4 we discuss our empirical results; and in Section 2.5 we summarize our conclusions and policy implications.

\subsection{Literature Review}

There are winners and losers when a carbon tax is introduced in an economy (Fullerton, 2011; Fullerton and Muehlegger, 2019; Bowen, 2015; Wang et al., 2016; Cronin et al., 2019). The overall distributional effect of this instrument is complex and influenced by many factors - such as the household consumption patterns, production structures and firm competition, distribution of co-benefits from improved environment quality ${ }^{2.13}$ and the carbon tax design. The latter, in particular, includes a number

\footnotetext{
${ }^{2.10}$ Brazil pledged to reduce its overall GHG emissions by $37 \%$ and $43 \%$ below 2005 levels in 2025 and 2030, respectively.

${ }^{2.11} 190$ parties submitted climate strategies for the 2015 Paris Agreement. Most strategies include objectives for both mitigation (reducing emissions) and adaptation (building resilience to climate change)(IMF, 2019).

${ }^{2.12}$ As stated in the NDC document, "Brazil reserves its position regarding the possibility of using any market mechanisms that may be established under the Paris Agreement" (BRASIL, 2015a).

${ }^{2.13}$ Carbon pricing can produce significant environmental co-benefits, for example, reduced air pollution from coal combustion and externalities like reduced congestion from motor vehicles, at least until these other externalities are fully priced through other policies. Co-benefit estimates can be quite large, averaging USD 57.5 per tonne of CO2 across the top-twenty emitters, though with substantial
} 
of important factors, each of which has implications in terms of effectiveness and distribution: who should pay the tax, what should be taxed, how much is the tax rate and the use of tax revenue (also called preferential policy design).

Wang et al. (2016) and Ohlendorf et al. (2018) provided a very comprehensive literature review on distributional impacts of carbon taxes, particularly on different income groups of households. In general, existing studies focus mainly on the cost distribution and observe regressive impacts of an economy-wide carbon tax in higherincome countries, even when considering both direct and indirect impacts - that is, accounting for emissions related to fossil fuel use and production of goods and services for final consumption, as well as substitution and income effects at the household level. This overview is consistent with the Intergovernmental Panel on Climate Change (IPCC) (Edenhofer, 2015), which indicates that the impacts of national carbon taxes on consumers would likely be somewhat regressive in high-income countries.

For example, using an I-O model and applying a direct and indirect average tax of 81 euro/year and 35 euro/year in Denmark, Wier et al. (2005) found that low-income families paid carbon taxes constituting around $0.8 \%$ of disposable income, while high-income families paid approximately $0.3 \%$ of disposable income. In Sweden, Brännlund and Nordström (2004), based on a household demand model (Quadratic Almost Ideal Demand System (QUAIDS)), observed that poorest and richest households experience a welfare loss of $0.52 \%$ and $0.33 \%$ of their disposable income, respectively, for a $100 \%$ increase of the $\mathrm{CO}_{2}$ price, which was based on USD $46 / \mathrm{tCO}_{2}$. The regressive nature of $\mathrm{CO}_{2}$ taxes in both studies can be explained by two factors: i) $\mathrm{CO}_{2}$ intensities vary strongly between consumption goods, with food and transport being very $\mathrm{CO}_{2}$ intensive, and services and financial transfers being at the other end of the scale; and ii) low-income cohorts mainly consume carbon-intensive necessities, while high-income cohorts spend a large part of their income on "luxury" items that have a higher service component. Since carbon taxes in Denmark and Sweden were introduced in 1992 and 1991, respectively, the findings from these studies correspond to de facto effects.

Using an I-O model combined with consumer expenditure survey for the U.S., Grainger and Kolstad (2010) observed that, for a tax of USD $15 / \mathrm{tCO}_{2}$, the poorest quintile's burden (as a share of annual income) is 3.2 times that of the wealthiest quintile. Similar results were also found by Hassett et al. (2007), where the additional cost of a carbon tax was approximately $3.7 \%$ for the lowest decile, which is over four

cross-country variation (e.g., due to sharp differences in population exposure to pollution) (Parry et al., 2015). 
times the added burden of the highest decile. These studies suggest that the regressivity of the policy is driven largely by direct energy consumption.

However, progressive effects were found in empirical studies for Italy and British Columbia. Tiezzi (2005), through estimation of an Almost Ideal Demand System (AIDS) model and using household data from 1985 to 1996, verified that the welfare losses as a percentage of expenditure were $0.4 \%$ and $0.8 \%$, respectively for Italian households in the lowest and highest expenditure levels. This might be due to the fact that the taxation mainly fell on transport fuels, whereas heating' fuel prices increased relatively less. The tax burden also seems to affect mainly households with one and two adults and decreases for larger families, which could be explained by the fact that the tax burden due to car ownership, for instance, is more distributed as the number of household members increases, because the number of car owned does not increase linearly with the number of household members. Beck et al. (2015), using a static CGE model of the Canadian economy, estimated that a carbon tax of USD 30/t applied on all combustion GHGs would cause welfare losses of $0.2 \%$ and $0.6 \%$ for poorest and richest households, respectively. The progressive character of the tax would be enhanced by the introduction of revenue recycling measures - the poorest households would present an increase of $0.8 \%$ in welfare while richest households would have their welfare levels reduced by $0.2 \%$.

In the limited number of studies focusing on developing economies, the results are more diverse. Combining emission information estimated via an I-O model, together with micro data from the Mexican National Survey of Household Incomes and Expenditure, Renner (2018) found that, in the case of the highest simulated tax rate of USD $50 / \mathrm{tCO}_{2} \mathrm{e}$ and including $\mathrm{CH}_{4}$ and $\mathrm{N}_{2} \mathrm{O}$ in the taxation, the relative welfare losses would be $4.2 \%$ and $3.4 \%$ of total expenditures for the poorest and richest households respectively, while in the case of a carbon tax rate of USD $20 / \mathrm{tCO}_{2}$ exclusively taxing $\mathrm{CO}_{2}$ from energy use, welfare losses would be progressive and account for around $1 \%$ of total expenditures for all households.

In contrast, based on an econometric model, Brenner et al. (2007) observed that with a charge set at 300 yuan $/ \mathrm{tCO}_{2}{ }^{2.14}$, and with equal redistribution of the revenues, the effect of the carbon charge would be progressive in China: the lowest decile would pay $2.1 \%$ of total expenditures to satisfy the levy, and the highest decile would pay $3.2 \%$. Using a general-equilibrium (CGE) model for South Africa, Devarajan et al. (2011)

\footnotetext{
${ }^{2.14}$ The rate was comparable to existing carbon charges in other countries in 1999.
} 
indicated that, compared to other instruments, a direct tax on carbon emissions imposes the lowest distortion, where household welfare declines by roughly $0.3 \%$ in order to reduce emissions by $15 \%$. On the other hand, an indirect tax on pollution-intensive commodities imposes a higher cost - by as much as 10 times that of a carbon tax. When assessing the results of a USD $30 / \mathrm{tCO}_{2}$ tax for different income groups in 87 low- and middle-income countries (countries with per capita incomes below USD 15,000 per year (at PPP-adjusted 2011 USD)) and using a multi-regional I-O table, Dorband et al. (2019) found that carbon pricing has, on average, progressive distributional effects. Due to an inverse U-shape relationship between energy expenditure and income, the authors noted that USD 15,000 (PPP-adjusted) is actually the turning point at which carbon pricing is likely to be progressive (and regressive above this threshold).

Results of previous studies for Brazil are also diverse. Grottera et al. (2017), considering a $\mathrm{R} \$ 50 / \mathrm{t}$ tax on carbon dioxide $\left(\mathrm{CO}_{2}\right)$, methane $\left(\mathrm{CH}_{4}\right)$ and nitrous oxide $\left(\mathrm{N}_{2} \mathrm{O}\right)$ emissions and using an input-output model for 2005, found that despite the markedly recessive effect when the revenue is not reinserted into the economy, the measure is progressive since income inequality decreases, especially if direct transfer to households is considered. However, when the revenue is used to reduce taxes on the labor factor, the carbon tax contributes to increase income inequality. Based on the same method and tax rate, Freitas et al. (2016) estimated welfare losses measured by compensatory variation of $3.1 \%$ and $1.2 \%$ for lower and higher income deciles, respectively. Similarly, considering the same tax applied on GHG emissions and using a computable general equilibrium (CGE) model, Magalhães et al. (2013) found that the poorest and richest households would reduce their total consumption by $2.2 \%$ and $1.8 \%$, respectively, in a scenario without any revenue recycling, but when considering recycling to households of that part of the revenues from the carbon tax, the reductions were $1.2 \%$ and $0.9 \%$, respectively.

As observed, the tax rate simulated and implemented varies considerably among the countries. Wang et al. (2016) indicated that these rates can be either based on what is perceived as politically feasible, or based on the marginal abatement cost of carbon, or simply on budget requirements. In the last report prepared by the High-Level Commission on Carbon Prices (Stiglitz et al., 2017), it was concluded that carbon prices of USD $40-80 / \mathrm{tCO}_{2}$ and USD $50-100 / \mathrm{tCO}_{2}$ would be necessary in all countries to achieve the targets of the Paris Agreement by 2020 and 2030, respectively. However, about three-quarters of emissions covered by existing carbon pricing schemes are priced at less than USD $10 / \mathrm{tCO}_{2} \mathrm{e}$ (Timilsina, 2018), suggesting that these tax rates are 
relatively low compared to what actually is needed to achieve internationally agreed climate targets in the long-run (Boyce, 2016; Pindyck, 2013).

In general, the literature shows that the selection of income or expenditure to measure the relative cost may also affect the results. The studies which focus on the general effects of carbon taxes on well-being are more likely to adopt measures of expenditure rather than income due to three reasons, according to Flues and Thomas (2015): i) current consumption measures the current standard of living better than current income, based on the premise that households derive utility from the consumption of goods and not from income (Ravallion, 1992); ii) expenditure is likely to be a better (though still imperfect) proxy for lifetime well-being than income and iii) adopting an expenditure base provides a more reliable picture of the lifetime distributional effects of a consumption tax because it removes the influence of borrowing and saving from the analysis. Therefore, measures of regressivity are often diminished when evaluated according to lifetime income or permanent income, or a proxy such as annual expenditures (Cronin et al., 2019).

Overall, the empirical assessments indicate that the revenue generated through the tax could also be used to counteract potential negative distributional impacts and potentially generate double dividends (Goulder, 1995; Fullerton and Metcalf, 1997). Some of the options for using the revenue earned from carbon taxes include ex-ante measures, such as public transport subsidies (Brännlund and Nordström, 2004), as well as ex-post measures, such as lump-sum transfers to households (Sajeewani et al., 2015; Brenner et al., 2007), and relief of existing and naturally distorting taxes on labour, income or revenues (Callan et al., 2009; Pereda et al., 2019). The studies suggest that low income households would benefit more when carbon tax revenue is recycled as a lump-sum rebate than used to cut existing taxes. If the carbon tax revenue is used to cut existing taxes, higher income households will benefit the most (i.e., their welfare loss due to the carbon tax decreases) (Timilsina, 2018).

In theory, for efficiency and fairness purposes, the tax should be applied as broadly as feasible to all greenhouse gas emissions, regardless the source. In light of the practical experience of countries that have introduced a carbon tax, along with studies proposing and modeling a hypothetical carbon tax, Wang et al. (2016) stated that the tax generally is levied on fossil fuels from both primary (e.g., oil, coal, biomass) and secondary (e.g., electricity, fuel oil) energy sources. Broader coverage tends to be more cost-effective to reduce emissions, since the same marginal incentive for reductions is observed across a broad range of sources. They also have higher revenue potential 
and are considered simpler and fairer. Narrow coverage, on the other hand, is easier to measure and to enforce (particularly for downstream taxation, which is harder to monitor and enforce) and could exempt vulnerable/politically powerful sectors.

In addition, the positioning of regulation is also an important element in the design of a carbon tax. There often exist "upstream" or "downstream" choices in the energy chain to impose the tax, to minimize collection and monitoring costs and to ensure maximum coverage. In an upstream approach, refineries and importers would pay a tax based on the carbon content of their gasoline, diesel fuel, or heating oil; coal mine operators would pay a tax reflecting the carbon content of extracted coal; and natural gas companies would pay a tax reflecting the carbon content of their produced and imported gas. A downstream point of regulation or taxation would assign compliance responsibilities to the final emitters. Alternatively, a hybrid upstream-downstream approach could address a broad base, such as in a system that covers power plants' direct emissions and transportation's embedded emissions, with refineries serving as the point of compliance for petroleum fuels (Aidy, 2017). In the absence of the hybrid approach, Metcalf and Weisbach (2009) pointed out that imposing the tax upstream could cover a broader base (i.e., a larger fraction of an economy's emissions) and more economies of scale could be obtained in tax administration as there are fewer upstream producers than downstream consumers and the cost will be lower per unit of tax. Also, an advantage of an upstream system is that it treats all fossil carbon equally, regardless of where it is burned. Arguments for downstream (e.g., households or energy-using industries) imposition of the tax tend to be based on a claim that a downstream tax is more visible and, therefore will have a greater effect.

Much of the research on the distributional impact of a carbon tax relies on I-O models in combination with household expenditure surveys. The I-O model is used to analyze the direct and indirect consumer price changes caused by higher fossil fuel prices. Subsequently, these prices are combined with data from consumer expenditure surveys to estimate incidence of the carbon tax. However, this modeling approach misses some important elements that can have significant impacts on the incidence of the policy: it does not allow industries or households to change their behavior in response to increases in the price of carbon intensive commodities, and assumes an inherent homogeneity in the sector-by-sector technology. Additionally, possible constraints to the supply of production factors - such as labor and capital - are not taken into account, and generally the models assume full pass-through of price increases from producers to consumers in the form of higher prices. Since it is a static analysis, these models present stocks at a 
given period of time. As a result, these models highlight the short run distributional outcomes rather than the dynamic effects of a carbon tax on production techniques and consumption bundles (Mathur and Morris, 2014).

A wide range of empirical studies on the distributional aspects of environmental policies also have used computable general equilibrium (CGE) models. In particular, studies which take into account recycling schemes for carbon pricing tend to use this approach. These models provide a higher degree of flexibility in choosing functional forms to represent agents' behavior and also allow substitutions between factors and inputs, as well as passing the burden of a tax forward to consumer prices or backward to factors. Despite that, studies using CGE models have found that consumption taxes are entirely passed forward to consumers (Metcalf and Weisbach, 2009), as expected under perfect competition. Boyce (2016) relaxed this assumption by allowing some of the cost to fall on producers and, ultimately, stock owners, which makes a carbon tax less regressive. In addition, econometric models have also been used to assess the distributional impacts of a carbon tax, through the estimation of a consumer demand system, generally in combination with the I-O approach. By assessing behavioral response, these models tend to be more flexible, allowing complementarities and substitution relationships among the goods, which can improve the identification of the distributional effects. Commonly used econometric models are almost ideal demand systems (AIDS) (Tiezzi, 2005), their more flexible quadratic specification (QAIDS) (Brännlund and Nordström, 2004; Nikodinoska and Schröder, 2016) or more recently the exact affine Stone index (EASI) demand system (Reaños and Wölfing, 2018).

\subsection{Empirical Strategy and Data}

An analysis of the distributional emission and welfare consequences of a carbon tax requires detailed data on households' carbon footprints and a clear understanding of their consumption behavior. First, we calculate GHG emission coefficients for several products and services consumed by Brazilian households using a hybrid input-output (HIO) approach. Then, for a nationally representative sample of Brazilian households, we calculate expenditure and price elasticities for these goods and services using a censored demand system. Finally, we combine these estimates in order to measure the welfare and emission effects of a carbon tax. 


\subsubsection{Emission coefficients: input-output model}

We use the national input-output matrix for 2010, built according to Guilhoto et al. (2010). This matrix is constructed based on the 2010 Supply-Use Tables (SUTs) provided by the Brazilian Institute of Geography and Statistics (IBGE) and contains information on production and intermediate consumption, in monetary units, of 128 products and 68 economic sectors. To obtain the carbon footprint of goods and services, we develop a hybrid matrix $\left(\boldsymbol{E}_{\text {exn }}\right)$ containing the amount of energy consumed - expressed in physical units (tonnes of oil equivalent, toe) of e sources of energy in $n$ economic sectors $(e<n)$ - by each sector, based on information from the Brazilian Energy Balance (BEN). The matrix $\boldsymbol{E}_{\text {exn }}$ provides energy requirements (in toe) for 21 economic sectors from 24 energy sources ${ }^{2.15}$.

We follow Montoya et al. (2014) and Grainger and Kolstad (2010) to reconcile the energy sources from BEN with the products from SUTs. Then, in the matrix $\boldsymbol{Z}$, which represents the inter-industrial transactions -, we substitute the monetary flow by the energy intermediate input flows, creating the hybrid matrix $\boldsymbol{Z}^{*}$. We repeat the same procedure for the total production vector $\left(\boldsymbol{X}^{*}\right)$ and the final demand vector $\left(\boldsymbol{Y}^{*}\right)$. The technical coefficient matrix in hybrid units $\left(\boldsymbol{A}^{*}\right)$ can be calculated by:

$$
\boldsymbol{A}^{*}=\boldsymbol{Z}^{*}\left(\hat{\boldsymbol{X}}^{*}\right)^{-1}
$$

The energy consumption in toe is then converted into the three main long-term drivers of climate change, $\mathrm{CO}_{2}, \mathrm{CH}_{4}$ and $\mathrm{N}_{2} \mathrm{O}$ and later to $\mathrm{CO}_{2} \mathrm{e}$ based on the energy conversion coefficient for fossil fuels ${ }^{2.16}$ available from the Second Brazilian Inventory of Greenhouse Gas Emissions, which follows the IPCC Guidelines for National Greenhouse Gas Inventories (IPCC, 2007) and the global warming potential (GWP) conversion factors ${ }^{2.17}$.

\footnotetext{
${ }^{2.15}$ Energy generated by self-producers was not added since the majority of this energy is consumed by the same companies and therefore does not generate added value. Imported energy (which corresponded to approximately $7 \%$ of total energy supply in 2010) was also not included in our calculations since it was not possible to identify its respective sources.

${ }^{2.16}$ These conversion coefficients that take into account the characteristics of the chemical process and technology applied to each greenhouse gas. The following fuels were considered: natural gas, steam coal, metallurgical coal, diesel oil, fuel oil,gasoline, LPG, kerosene, gas coke, coal coke, other oil byproducts, and coal tar.

${ }^{2.17}$ The "global warming potential" (or GWP) of a GHG indicates the amount of warming a gas causes over a given period of time (normally 100 years). GWP is an index, with $\mathrm{CO}_{2}$ having the index value of 1, and the GWP for all other GHG is the number of times more warming they cause compared to $\mathrm{CO}_{2}$. E.g. $1 \mathrm{~kg}$ of methane causes 25 times more warming over a 100 year period compared to $1 \mathrm{~kg}$
} 
Assuming that $\mathrm{CO}_{2} \mathrm{e}$ emissions by energy use are linearly related to the respective energy requirements, it is possible to estimate both direct emissions as well as total emissions for each good and economic activity. The matrix of technical coefficients of national inputs $\boldsymbol{A}_{p}$, is obtained by the product of $\boldsymbol{B}^{*}$ and $\boldsymbol{D}$. The matrix $\boldsymbol{B}^{*}$ contains, in hybrid units, the proportion of each domestic input used in the total production of a specific sector:

$$
b_{i j}=\frac{u_{i j}^{*}}{\sum_{i} r_{i j}}
$$

where $u_{i j}^{*}$ is the element $i j$ of the hybrid 'use' matrix, denoting the amount of domestic input $i$ used in the production of sector $j$, and $\sum_{i} r_{i j}$ is the total production of sector $j$. Likewise, we calculate the share of product $i$ produced by sector $j\left(d_{i j}\right)$ as follows:

$$
d_{i j}=\frac{r_{i j}}{\sum_{j} r_{i j}}
$$

The coefficients of matrix $\boldsymbol{A}_{p}$ can be interpreted as the quantity of $\mathrm{CO}_{2}$ e that product $i$ uses to produce one unit of product $j$ (expressed in tonnes $\mathrm{CO}_{2} \mathrm{e} / \mathrm{USD}$ mi, in 2009 values $^{2.18}$. Direct $\mathrm{CO}_{2}$ e emission is equivalent to the sum of the $k$ rows of the $\boldsymbol{A}_{p}$ that measure emissions:

$$
c_{i, C O_{2} e}=\sum_{k} a p_{k j}
$$

in which $k \leq i$. We follow Minx et al. (2009) to calculate total emissions, equivalent to direct plus indirect emissions:

$$
c_{i, C O_{2} e}^{T}=\left(I-\boldsymbol{A}_{p}\right)^{-1} * Y * c_{i, C O_{2} e}
$$

where $Y$ is the vector of final demand. Therefore, the emission coefficient of the products corresponds to the $\mathrm{CO}_{2}$ e content embedded in one monetary unit of the respective product.

of $\mathrm{CO}_{2}$, and so methane has a GWP of 25 .

${ }^{2.18}$ To reconcile with the Budgetary Household Survey, we converted 2010 values into 2009 values. 
Based on the premise of constant technological coefficients and returns to scale, the hybrid I-O model assumes no price substitution effect on consumption or production processes. It also considers that all interactions among components of the economy occur at the same time, instead of in a dynamic way.

However, the premise of strict prices is adjusted by the estimation of a censored demand system, as detailed in Section 2.3.2. Therefore, emissions reductions are exclusively due to consumption changes. In addition, our emission coefficient estimates include exports but exclude imports and do not take into account carbon leakages ${ }^{2.19}$.

Figure 2.1 (Appendix) presents the estimates for the direct and indirect emission coefficient for the goods and services consumed by Brazilian households, presented in decreasing order of relative $\mathrm{CO}_{2}$ e emissions. We note very high coefficients for water and air transportation, as well as ground transportation of cargo and passengers, followed by wood products, cement, glass/ceramics, and food items such as dairy products, meat, beverages and canned foods. Total emissions tend to arise mainly from indirect emissions for most activities, which indicates there is higher energy consumption from the trade flows to meet the final demand for these respective goods/services. However, particularly for all types of transportation, wood products, paper and printing services, as well as selected agricultural and livestock products (such as rice, milk, cattle, poultry, eggs and fish), direct emissions might represent up to $90 \%$ of overall emissions. Therefore, these products/services exert significant influence on total GHG emissions in Brazil.

\subsubsection{Households' responses to prices: censored QUAIDS}

Carbon taxation mainly affects household expenditures on energy-related products and services like fuel and transportation, as these goods become more expensive. However, since carbon taxation also affects expenditures on non-energy related products by shifting the share of the household budget that is spent on each type of product, there is a need to understand the whole consumer behavior change caused by price modifications.

Consumer behavior theory says that individuals choose what and how much to consume to maximize their well-being, subject to a budget constraint. If the consumer's

\footnotetext{
${ }^{2.19}$ Carbon leakage refers to the phenomenon where overseas emissions (especially from those in countries with less strict environmental regulations) increase because of emissions restrictions in a given country.
} 
set of choices is consistent ${ }^{2.20}$, the study of consumer behavior can be performed as a classic optimization problem ${ }^{2.21}$, allowing the estimation of price and income elasticities.

However, consumer theory does not specify the functional forms for the demand equations. The advantage of estimating a system of demand equations instead of individual equations is based on the joint estimation and empirical tests concerning the validity of the theoretical restrictions implied in the consumer theory. We choose the Quadratic Almost Ideal Demand System (QUAIDS), which considers the nonlinearity of income, as presented below:

$$
w_{i}=\alpha_{i}+\sum_{j=1}^{n} \gamma_{i j} \ln \left(p_{j}\right)+\beta_{i} \ln \left(\frac{m}{a(p)}\right)+\frac{\lambda_{i}}{b(p)}\left[\ln \left(\frac{m}{a(p)}\right)\right]^{2}
$$

where $w_{i}$ is the expenditure for good $i, p_{j}$ is the price of good $n, m$ is the total expenditure per capita and $\ln \alpha(p)$ is the transcendental price index, such that:

$$
\ln [a(p)]=\alpha_{0}+\sum_{i}^{n} \alpha_{i} \ln \left(p_{i}\right)+1 / 2 \sum_{i} \sum_{j} \gamma_{i j} \ln \left(p_{i}\right) \ln \left(p_{i}\right)
$$

and $b(p)$ is the Cobb-Douglas price aggregator, described as:

$$
b(p)=\prod_{i=1}^{n} p_{i}^{\beta_{i}}
$$

and

$$
\lambda(p)=\sum_{i} \lambda_{i} \ln p_{i}
$$

The theoretical constraints on the model's parameters are:

$$
\sum_{i=1}^{N} \alpha_{i}=1 ; \sum_{i=1}^{N} \beta_{i}=0 ; \sum_{i=1}^{N} \lambda_{i}=0 ; \sum_{i=1}^{N} \gamma_{i j}=0, \forall j \in I
$$

\footnotetext{
${ }^{2.20}$ The consistency of preferences implies acceptance of the axioms of reflexivity, completeness, transitivity, continuity, no local satiety and strict convexity (Deaton and Muellbauer, 1980b).

${ }^{2.21}$ Due to consistency of consumer preferences, the system of demand equations has the properties of additivity, homogeneity, symmetry and negativity.
} 


$$
\begin{gathered}
\sum_{j=1}^{N} \gamma_{i j}=0, \forall i \in I \\
\gamma_{i j}=\gamma_{j i}, \forall i \neq j
\end{gathered}
$$

Following the demographic translation approach by Pollak and Wales (1981), we introduce sociodemographic shifters $\left(z_{j}\right)$ by substituting Eq. 2.13 into Eq. 2.6 and Eq. 2.7. Demographic shifters are used to allow for household heterogeneity:

$$
\alpha_{i}^{*}=\alpha_{i}+\sum_{j=1}^{n} \delta_{i j} z_{j}
$$

This procedure requires one additional constraint to the system of equations $\left(\sum_{j=1}^{n} \delta_{i j}=0, \forall i \in 1, \ldots, n\right)$.

The empirical estimation of a demand system requires household expenditure data. We use data from the 2008-09 Brazilian Household Expenditure Survey, a nationally representative cross-sectional survey that contains data on all monetary and nonmonetary household and individual expenses ${ }^{2.22}$ during a given period, presented in different booklets. Food and beverage expenses are collected for a 7-day period; building material expenses, rent and taxes are compiled for a 12-month period; expenses related to the consumption of energy goods (electricity and fuels) are collected for a 90-day period; while individual expenses for transportation, education, meals outside the home, medicines, clothing and footwear, hygiene, health, furniture and vehicle acquisitions vary according to the good/service. The sample is based on a two-stage clustered sampling procedure, with a probabilistic selection of 550 household census sectors. Households within each sector are selected by simple random sampling without replacement and the interviews were carried out uniformly throughout the survey's four quarters to reproduce the seasonal variation in income and purchases in each stratum. For the purpose of this study, we use the household as the unit of analysis.

We use the IBGE official translator ${ }^{2.23}$ to reconcile almost 14,000 products available in the Household Expenditure Survey (POF) according to their similarity

\footnotetext{
${ }^{2.22}$ The level of detailed information on monetary and non-monetary expenses and income from POF allows minimization of the under-declaration problem (Hoffmann, 2010).

${ }^{2.23}$ Available at:<https://www.ibge.gov.br/estatisticas/economicas/contas-nacionais/ 9052-sistema-de-contas-nacionais-brasil.html?edicao=25916\&t=notas-tecnicas $>$
} 
with the 98 products consumed by households in SUTs ${ }^{2.24}$. After this aggregation, we follow Ghalwash (2007) and Dorband et al. (2019) to group the combined categories of products into similar 9 main groups, which allows the understanding of the total household consumption: i) food and beverages, ii) recreation, culture and education, iii) clothing and footwear, iv) commuting and transportation, v) health and hygiene, vi) energy, vii) housing, viii) other goods and ix) other services. Table 2.1 provides a description of the items included in each of these main categories.

The use of household expenditure survey data for demand system estimation often creates a problem due to the lack of consumption of certain goods during the recall period. This causes censored dependent variables and leads to biased results when not accounted for. Following Shonkwiler and Yen (1999), the consumption of each good can be characterized as a two-stage decision: the first step corresponds to a probit model with the same variables as the QUAIDS model, in which its cumulative distribution $(\hat{\Phi})$ and the probability density function $(\hat{\phi})$ are used in the second step to augment the QUAIDS estimation ${ }^{2.25}$ :

$$
w_{i}^{*}=\hat{\Phi}_{i} w_{i}+\hat{\phi}_{i}
$$

The expenditure (Eq. 2.15) and price elasticities (compensated, Eq. 2.16 and uncompensated, Eq. 2.17) formulas for the non-linear QUAIDS can be expressed as:

$$
\begin{gathered}
\eta_{i}=1+\Phi_{i} / w_{i}\left[\beta_{i}+\left(\frac{2 \lambda_{i}}{b(p)}\right) \ln \left(\frac{m}{a(p)}\right)\right] \\
\epsilon_{i j}=-\delta_{i j}+\Phi_{i} / w_{i}\left[\gamma_{i j}-\left(\beta_{i}+\left(\frac{2 \lambda_{i}}{b(p)}\right) \ln \left(\frac{m}{a(p)}\right)\right)\left(\alpha_{j}+\sum_{k} \gamma_{j k}-\ln p_{k}\right)-\frac{\lambda_{i} \beta_{i}}{b(p)}\left(\ln \left(\frac{m}{a(p)}\right)\right)^{2}\right.
\end{gathered}
$$

where $\delta_{i j}$ is the Kronecker delta (equal to one only for own price elasticities, and

\footnotetext{
${ }^{2.24}$ Some products available on SUTs are not consumed by households (e.g. pig iron and ferro-alloys).

${ }^{2.25}$ In the censored QUAIDS, the deterministic components on the right-hand side of Equation 2.14 do not add up to unity across all equations of the system in general, and so the error terms in the estimation form do not add to zero. Thus, the usual procedure of imposing the adding-up restriction (Eq. 2.10) on the system and dropping one arbitrary equation is not valid. Therefore, with censoring, the second step of the system (Eq. 2.14) is estimated correctly when using the entire set of equations (Yen et al., 2002).
} 
zero otherwise):

$$
\epsilon_{i j}^{h}=\epsilon_{i j}+\left(\frac{\beta_{i}}{w_{i}}+1\right) w_{j}
$$

To capture the heterogeneous effects of the energy tax policies, elasticities are calculated for the overall sample and among the $20 \%$ richest and $20 \%$ poorest households in the dataset. We use the information of total earnings as stated in the POF, which contains wage, transfers, rental income, non-cash and other incomes to disaggregate the groups per different income levels.

All models are estimated by feasible generalized non-linear Least squares (FGNLS), and standard errors are computed by nonparametric bootstrap with 1,000 repetitions. Since $\alpha_{0}$ is difficult to estimate (Deaton and Muellbauer, 1980b), we follow Boysen et al. (2012) and adopt an arbitrary and low value of 5. Other values did not change the resulting elasticities but caused the procedure to require many more iterations to converge. Robustness checks are also conducted using uncensored QUAIDS and AIDS models with the STATA procedure suggested by Poi et al. (2012) with the same specification.

This partial equilibrium framework assumes that the carbon tax burden is fully transferred to consumers. This is a reasonable assumption to be used in an assessment of the immediate impact given the structural stability in the short-term, in which the reallocation of factor input is unlikely(Grainger and Kolstad, 2010; Metcalf and Weisbach, 2009). In addition, the impact of a carbon tax on consumption in a demand system approach excludes the behavioral changes and possible welfare benefit received from reduced emissions. Due to these limitations, the estimates can be interpreted as the carbon tax policy's upper bound effect.

Table 2.2 (Appendix) shows the descriptive statistics for positive consumption and budget shares for each group and income level. For instance, the household budget share allocated to food and beverage and energy consumption among the $20 \%$ poorest is more than double the proportion of spending on these products among the $20 \%$ richest households. For commuting and transportation services, as well as for recreation and education, this proportion is even higher. However, the richest and poorest households tend to spend similar shares on clothing and footwear and housing. Furthermore, on average, censoring is higher for health and hygiene items, as well as for culture and private education, mainly because poorer households have lower consumption of goods 
from these groups. Clothing and footwear expenses are presented in different booklets, which explains the high percentage of positive consumption for all income levels. Overall, these figures justify the use of the censored approach when using data from household expenditure surveys.

The descriptive statistics of socioeconomic variables is presented in Table 2.3 (Appendix), to help explain the differences in preferences of households for the products analyzed. Heads of the $20 \%$ richest households have almost 5 more years of education compared to the heads of the $20 \%$ poorest households. In addition, the richest group has more than twice as many rooms and bathrooms in their houses (good proxy for wealth) compared to the poorest group, on average. Total per capita earnings of high-income households are 15 times higher than for low-income households.

\subsubsection{Construction of prices}

The main theoretical variables for household demand system are, basically, total expenditures (proxy for income) $)^{2.26}$ and prices, calculated as unit values $\left(p_{i}=U V_{i}\right)$. Particularly for the products from group 1 (food and beverages), there are two main problems related to the price we calculate from the household expenditure surveys: potential measurement error, and differences in quality and packaging (Boysen et al., 2012). In this sense, we use a price correction method from Cox and Wohlgenant (1986) and Lazaridis (2003) for these specific products.

As not all household have positive consumption of all items, the missing observations are approximated by the average of $\hat{p}_{i}$ coefficients over the neighboring region first, the stratum and if it is still missing, the state. Then we compute the weighted price indexes $^{2.27}$ (Stone price index) for all groups (Deaton and Muellbauer, 1980a):

$$
\ln p_{g}=\sum_{i \in I_{g}} w_{i} \ln p_{i}
$$

in which $I_{g}$ is the set of items included in aggregate item group $g, p_{i}$ is the price and $w_{i}$ is the budget share of item $i$ in each household. Because expenditures and prices are endogenous in this demand system, we use households' disposable income as an

\footnotetext{
${ }^{2.26}$ Since household income is self-reported, this information might be associated with negative reporting bias. To overcome this issue, the literature usually adopts household total expenditure as a proxy for household income.

${ }^{2.27}$ For items of group 1, this procedure is implemented after the price correction.
} 
instrument for expenditures, and nearest neighbors' price indexes as instruments for household price indexes (Lecocq and Robin, 2015), controlling for diversity in household preferences such as their composition, age and geographical location.

In the POF, there is a limitation related to the lack of specification of the quantity consumed of several products and services: in a 12-month period (e.g., rent, taxes, construction and remodeling) and on an individual basis (e.g., education, commuting and transportation). This affects items aggregated into groups 2, 3, 4, 5, 7 and 9. We assume that the quantity consumed was equal to 1 for the households with positive consumption of the respective product or service. This approach tends to overestimate the unit value of some products and services, thus underestimating the respective price elasticities.

Based on these limitations, Table 2.4 (Appendix) presents the aggregated prices, in which values expressed in Brazilian reais of 2009 are converted to 2019 using the average exchange rate from the Central Bank of Brazil for that year. The price indexes should be interpreted as a relative price index: for example, richer households expend $34 \%, 78 \%$ and $67 \%$ more on food and beverages, commuting and transportation services and energy goods, respectively, compared to poorer households. The small standard deviation values are associated with the lack of information related to quantity consumed of several expenditure items.

\subsubsection{Calculation of effects}

Welfare and emissions effects, as well as the rationale behind revenue neutrality, are explained below. These effects are calculated for the average-income of Brazilian households as well as for the $20 \%$ richest and $20 \%$ poorest households, and the estimations are multiplied by the number of Brazilian households from the 2010 Brazil Demographic Census (approximately 57 million inhabitants) to calculate these effects for the country as a whole. Since the impacts calculated in this study are mainly valid for the short-run, they should be interpreted as upper bounds for long-term impacts.

\subsubsection{Welfare effects}

Assuming that prices are fully transferred to consumers and focusing only on the costs associated with the tax imposition, we use the concept of equivalent variation (EV) to assess the short-term effects of a carbon tax on welfare. The EV, expressed in 
monetary terms, indicates the maximum amount the consumer would be willing to pay to avoid a price change caused by the introduction of a tax:

$$
E V=e\left(p^{1}, u^{1}\right)-e\left(p^{0}, u^{1}\right)
$$

where $e$ is the expenditure function considering the ex-post utility $\left(u^{1}\right)$ at pre-tax and post-tax prices, respectively. Likewise, in a situation in which the taxpayer cannot take any action to influence the amount of taxes paid (tax evasion), the dollar magnitude of the welfare loss as measured by the EV will exceed the total tax revenue collected from the taxpayer - and the difference is defined as the deadweight loss of the tax or the excess tax burden. Therefore, the deadweight loss (DWL) (corresponding to the EV) represents the efficiency loss arising from the tax - that is, utility that is lost beyond the revenue transferred to the government (Mohring, 1971):

$$
D W L\left(u^{1}\right)=E V-\left(p^{1}-p^{o}\right) h\left(p^{1}, u^{1}\right)
$$

where $h($.$) is the compensated demand function. One virtue of an equivalent$ variation measure of excess burden lies in the fact that in comparing tax policies that raise equal revenue, the tax policy with the lowest excess burden as measured by equivalent variation also produces the highest level of consumer welfare (Kay, 1980).

A key issue to examine the distributional effects of carbon taxes is how to measure the magnitude of tax burdens between poor and rich households. Many households in the lower income deciles either dis-save on previous earnings or may borrow against future earnings. Their level of expenditure reflects better what they are able to afford than their level of income (Cronin et al., 2019; Flues and Thomas, 2015). Since current consumption measures the current standard of living better than current income, we present both EV and DWL estimates relative to the total household expenditures.

\subsubsection{Emissions effects}

The difference between total GHG emissions before and after the tariff rate changes indicates the changes in total household carbon footprints due to the carbon 
tax policy, as follows:

$$
\Delta C O_{2} e=\sum_{g}\left(p_{g}^{1} * q_{g}^{1}\right) * c_{g, C O_{2} e}^{T}-\sum_{g}\left(p_{g}^{0} * q_{g}^{0}\right) * c_{g, C O_{2} e}^{T}
$$

\subsubsection{Neutral revenue}

We estimate the additional tax revenue collected by the government considering the tax rate, the total household expenditure and the carbon intensity of each group consumed. As per the "polluter pays" principle and the double-dividend rationale, we consider that the government revenue obtained from the carbon tax is fully redistributed to the households as a lump-sum transfer.

\subsubsection{Scenarios and sensitivity analysis}

Since tax rates implemented vary significantly worldwide, we simulate two scenarios considering USD $40 / \mathrm{tCO}_{2} \mathrm{e}$ and USD $80 / \mathrm{tCO}_{2} \mathrm{e}$. According to the HighLevel Commission on Carbon Prices - a group of leading economists working with the Carbon Pricing Leadership Coalition -, the explicit carbon-price level consistent with achieving the Paris temperature target is at least USD $40-80 / \mathrm{tCO}_{2}$ by 2020 and USD $50-100 / \mathrm{tCO}_{2}$ by 2030 . These estimates are also aligned with the prices calculated by the US Interagency Working Group on the Social Cost of Carbon of USD 50/tCO 2020. The International Monetary Fund (IMF, 2019) also estimates that prices from USD $50 / \mathrm{tCO}_{2}$ to USD $100 / \mathrm{tCO}_{2}$ or more by 2030 are needed to meet their commitments to reduce carbon emissions.

The rate is applied to $\mathrm{CO}_{2}, \mathrm{CH}_{4}$ and $\mathrm{N}_{2} \mathrm{O}$ emissions from fossil fuels to Brazil's 2009 productive structure and USD values for 2019. We also conduct sensitivity analysis by narrowing the tax base according to the groups of products and services that present the highest carbon content - food and beverages and commuting and transportation services, respectively. 


\subsection{Results and Discussions}

\subsection{1 $\quad \mathrm{CO}_{2} \mathrm{e}$ emission coefficients}

Table 2.5 (Apppendix) presents the estimates for total $\mathrm{CO}_{2} \mathrm{e}$ emissions per household - or carbon footprint -, obtained by multiplying total expenditures (at 2019 values) and the emission coefficient for each group of products. Food and beverages and commuting and transportation have the highest averages of $\mathrm{CO}_{2} \mathrm{e}$ emissions per household (3.3 tCO $\mathrm{tC}_{2} \mathrm{e} / \mathrm{hh} /$ year and $2.0 \mathrm{tCO}_{2} \mathrm{e} / \mathrm{hh} /$ year, respectively). Commuting and transportation mainly refers to cargo transportation, which is predominantly done over highway networks using diesel as fuel, and individual transportation, with prevalence of flex-fuel cars (ethanol and/or gasoline in any combination). It also accounts for public passenger transportation, largely by buses. Therefore, the high levels of $\mathrm{CO}_{2} \mathrm{e}$ emissions from the food and beverages group is a reflection of the country's characteristics of cargo transportation and the large expenditure share devoted to this group. The relatively low levels of $\mathrm{CO}_{2} \mathrm{e}$ emissions from the domestic energy group is explained by the fact that, on average, the majority of household expenditures refer to electricity and gasoline consumption. Despite an increasing share of production coming from natural gas and coal, electricity is still primarily generated by hydropower sources.

Other studies have found that carbon emissions embedded in transportation and commuting services, as well as food items, generally form a substantial portion of a household's carbon footprint, in particular when analyzed in terms of greenhouse gas emissions instead of carbon dioxide only. Differently from what we observe for Brazil, empirical studies of Australia (Dey et al., 2007), Netherlands (Nijdam et al., 2005) and UK (Druckman and Jackson, 2009) also point out that an important share of GHG emissions also arise from expenses related to heating, electricity and house maintenance, normally aggregated in the housing group.

Regarding the distribution of emissions among income levels, we note much higher figures for the richest $20 \%$ of Brazilian households, given that the total annual emissions in this category reach nearly $26 \mathrm{tCO}_{2} \mathrm{e}$ per household, far above the total calculated for the $20 \%$ poorest $\left(1.7 \mathrm{tCO}_{2} \mathrm{e}\right)$.

Indeed, many studies have shown that the relationship between income and household carbon footprint is strong (Wier et al., 2005; Dey et al., 2007; Perobelli et al., 2015). Our estimates suggest that almost $25 \%$ of total emissions from low-income 
households arise from food and beverage consumption, while $30 \%$ of GHG emissions from high-income households come from commuting and transportation services. Therefore, since expenditures on commuting and transportation increases with income, and this group has one of the highest emission intensity coefficients, these two coupled components play an important role in terms of reducing emissions. Likewise, households with lower income level tend to have a structure of spending that more intensively mobilizes the inputs related to the food production chain - such as transportation.

Our carbon footprint results also show adherence to the metrics disclosed by the World Bank ${ }^{2.28}$ for the Brazilian economy. According to its estimates, the average emission per household in Brazil was approximately $9.9 \mathrm{tCO}_{2}$ in 2014 , roughly in line with the average of $10.5 \mathrm{tCO}_{2}$ resulting from our approach. Furthermore, taking 2014 World Bank statistics as a benchmark, we find that the average emission per household in Brazil is significantly lower than the global average. Indeed, the average $\mathrm{CO}_{2} \mathrm{e}$ emission of the richest quintile in Brazilian population is below the average emission considering only $\mathrm{CO}_{2}$ in China (30 tCO 2 /household), Germany (35.6 tCO $\mathrm{tCO}_{2}$ /household) and United States ( $66 \mathrm{tCO}_{2} /$ household). Likewise, the average $\mathrm{CO}_{2} \mathrm{e}$ emission of the poorest quintile is much lower than the average $\mathrm{CO} 2$ emission in India $\left(6.8 \mathrm{tCO}_{2} /\right.$ household).

\subsubsection{Expenditure, own- and cross- price elasticities}

Table 2.6 (Appendix) presents the expenditure, own and cross-price elasticities of household groups, obtained through the demand system estimation. These elasticities measure the effectiveness of a pricing policy, such as a carbon tax, and determine the vulnerability of households in reducing their energy consumption when energy prices increase as a result of a carbon tax.

Expenditure elasticities for food items are low (0.8), especially for the $20 \%$ poorest households (0.5). This suggests that, compared to other groups, food demand is much less responsive to changes in income. On average, the expenditure elasticities for

\footnotetext{
${ }^{2.28}$ Data for carbon dioxide emissions include gases from the burning of fossil fuels and cement manufacture, but exclude emissions from land use such as deforestation. The U.S. Department of Energy's Carbon Dioxide Information Analysis Center (CDIAC) calculates annual anthropogenic emissions from data on fossil fuel consumption (from the United Nations Statistics Division's World Energy Data Set) and world cement manufacturing (from the U.S. Department of Interior's Geological Survey, USGS 2011). Estimates exclude fuels supplied to ships and aircraft in international transport because of the difficulty of apportioning the fuels among benefiting countries. Although estimates of global carbon dioxide emissions are probably accurate within $10 \%$ (as calculated from global average fuel chemistry and use), country estimates may have larger error bounds. Each year the CDIAC recalculates the entire time series since 1949, incorporating recent findings and corrections.
} 
domestic energy goods are relatively high (1.8), indicating that they are luxury goods for all levels of income - especially for low-income households (1.9). In contrast, expenditure elasticities for housing (which contains rent, as well as residential appliances) are relatively low (0.5) - particularly for high-income groups (0.2). Interestingly, for richer households, commuting and transportation services are considered necessity goods (0.9), while for poorer households they can be classified as superior goods (1.9). The demand for recreation and cultural activities from high-income households is less responsive to changes in income (0.6) compared to poorer households (3.9), being characterized as necessity goods and luxury goods for richer and poorer households, respectively.

One interpretation of these empirical results is that, in general, food, housing and other goods are seen as urgent needs, and thus as budgets increase, these services tend to be prioritized. Most goods and services are luxuries relative to food, housing and other goods - as income rise, the willingness to spend more on these goods and services increase more than proportionally. Saturation effects ${ }^{2.29}$ are also observed for energy, commuting and transportation, recreation and education as well as other services, meaning that richer households demand proportionally less goods and services from these groups but more of other goods and services. This suggests that consumption of and expenditure on many items previously considered to be luxury goods and services would grow less than income.

Studies estimating elasticities of several household expenditure groups using similar demand system approach have found income elasticities for food items ranging from 0.4 for Germany (Nikodinoska and Schröder, 2016) up to 0.7 for Italy (Tiezzi, 2005) and 0.80 for Sweden (Brännlund and Nordström, 2004). Our estimations related to commuting and transportation are similar to the ones found for Italy (Tiezzi, 2005) and Spain (Labandeira et al., 2006) for public transport (approximately 1.3). For Sweden, Ghalwash (2007) identified total expenditure elasticities of ranging from 0.2 to 0.4 for food and beverages, 2.1 for recreation, 1.1 for clothing, 0.5 for transports, 0.9 for health care and from 0.3 to 1.2 for energy goods. Also for Germany, Reaños and Wölfing (2018) found that expenditure elasticities for energy goods are typically smaller in absolute value among more affluent households.

Uncompensated (Marshallian) and compensated (Hicksian) own-price elasticities show the expected negative signs. On average, household demand is inelastic with

\footnotetext{
${ }^{2.29}$ Saturation effects imply that beyond a certain level of consumption, there is a declining share of the budget allocated to certain goods and services as incomes rise - and thus income elasticities for those good and services also fall.
} 
respect to the consumption groups with high embodied carbon content. Low-income households are less price-responsive for the majority of carbon-intensive categories (food and beverages (-0.8), commuting and transportation (-0.4), energy (-0.8), housing (-0.8) and other goods (-0.3)). For these categories, richer households presents elasticities of -1.0 (Food and Beverages), -1.1 (commuting and transportation, energy, housing and other goods). Therefore, poorer households can be expected to reduce their consumption less than rich households due to tax-induced price increases in these categories, while the reduction in health and hygiene (-1.6), recreation and education (-1.4), clothing and footwear (-1.5) and other services (-1.3) is relatively higher. Considering responses in demand, the real expenditure loss would, therefore, be higher for poorer households, which would make distributional effects more regressive.

Our findings are aligned with Labandeira et al. (2017), Ghalwash (2007) and Dorband et al. (2019). In particular, Dorband et al. (2019) assessed the expected incidence of moderate carbon price increases for different income groups in 87 mostly low- and middle-income countries and found own-price elasticities ranging from - 0.4 to -0.7 for food, beverages and tobacco, -0.7 for clothing and footwear and -0.7 for education.

The compensated own-price elasticities (used in the calculation of welfare effects) indicate similar patterns but in lower absolute terms since only the substitution effect is included and expenditure elasticities are all positive. Cross-price elasticites (Tables 2.7 and 2.8, Appendix) suggest that, in general, the groups with the highest $\mathrm{CO}_{2} \mathrm{e}$ emission coefficient (commuting and transportation and other goods) are substitutes for food items. Food and beverages are also substitutes for housing and commuting and transportation services. Commuting/transportation is also a substitute for housing and energy. However, energy goods appear to be complementary for housing.

In general, the findings suggest larger behavioral adjustments for rich households when facing changes in prices of carbon-intensive goods and services - such as food, commuting and transportation and recreation - while low-income households are already required to focus on their basic needs. Thus, high-income households should generate more emissions and a small variation in the consumption could have a significant impact on emissions. In addition, changes in the quantity demanded of food items appear to have a significant impact on the consumption of other carbon-intensive goods and services, and therefore influence the overall $\mathrm{CO}_{2} \mathrm{e}$ emissions. 


\subsubsection{Welfare and emissions effects}

Table 2.9 (Apppendix) presents our analysis of the distributional implications of an economy-wide carbon tax of USD $40 / \mathrm{tCO}_{2} \mathrm{e}$ and USD $80 / \mathrm{tCO}_{2} \mathrm{e}$ on welfare and emissions, in absolute terms and as a percentage of total household expenditure. The results indicate that the first-dividend effect is observed and the taxation policy is capable of achieving its main goal: to reduce emissions.

On average, a carbon tax of USD $40 / \mathrm{tCO}_{2} \mathrm{e}$ would be able to reduce overall household emission by $2.0 \%$ per year (equivalent to a reduction of $12.5 \mathrm{MtCO}_{2} \mathrm{e}$ ), reaching approximately $4.2 \%\left(25.2 \mathrm{MtCO}_{2} \mathrm{e}\right)$ considering a tax of USD 80/tCO $2 \mathrm{e}$. Highincome households are mainly responsible for the largest part of the reduction of total emissions, accounting for decreases of $7.6 \mathrm{MtCO}_{2} \mathrm{e}(-2.5 \%)$ and $14.6 \mathrm{MtCO}_{2} \mathrm{e}(-4.9 \%)$ per year, respectively. This pattern of emission reduction has been largely observed in many other empirical studies of developed countries (Grainger and Kolstad, 2010; Fremstad and Paul, 2019) as well as of other developing countries (Renner, 2018; Brenner et al., 2007), including Brazil (Magalhães et al., 2013; Freitas et al., 2016).

Regarding the welfare impact associated with the carbon tax (measured as equivalent variation in monetary equivalent of the change in utility), we observe aggregate welfare losses of USD $237 \mathrm{mi}$ and USD $244 \mathrm{mi}$ for a carbon tax of $40 / \mathrm{tCO}_{2} \mathrm{e}$ and $80 / \mathrm{tCO}_{2} \mathrm{e}$ respectively, approximately $0.02 \%$ of total household expenditure, respectively. The taxes raise the price of more carbon-intensive products and reduce $\mathrm{CO}_{2} \mathrm{e}$ emissions by their negative impact on consumption, thus lowering welfare in all cases (since the social, economic and environmental benefits of reducing $\mathrm{CO}_{2} \mathrm{e}$ emissions are not taken into account in this analysis).

We also identify the disproportionality of the welfare losses induced by the carbon tax across different types of households. The higher share of EV as a percentage of expenditure for poorest households $(0.10 \%)$ vis-a-vis richer households $(0.06 \%)$ suggests that the policy is regressive. Results also indicate that even at the higher tax rate considered (of USD $80 / \mathrm{tCO}_{2} \mathrm{e}$ ), the carbon tax has very little incremental impact on the behavior of households. Using similar tax rates, welfare losses of higher magnitude were found for low-income households in Sweden $(0.52 \%$; Brännlund and Nordström (2004)), Denmark (0.8\%; Wier et al. (2005)), U.S. (3.7\%; Grainger and Kolstad (2010), Hassett et al. (2007)), Mexico (4.2\%; Renner (2018)), Italy (0.4\%; Tiezzi (2005)) and Brazil - (3.1\%; Freitas et al. (2016)) and 2.2\%; Magalhães et al. (2013)). 
However, due to the consumption patterns, the deadweight loss estimates caused by the carbon tax show that richer households would have an additional tax burden of 0.04\% over the total expenditure per year (USD 205 million and USD 209 million for a USD $40 / \mathrm{tCO}_{2} \mathrm{e}$ and USD $80 / \mathrm{tCO}_{2} \mathrm{e}$ tax, respectively), compared to $0.02 \%$ faced by poorer households.

The results also indicate that with a tax rates of USD $40 / \mathrm{tCO}_{2} \mathrm{e}$ and USD $80 / \mathrm{tCO}_{2} \mathrm{e}$, and a relatively broad tax base - levied across all goods and services in the Brazilian economy based on its carbon content -, the government could increase its revenues by USD 616 million and USD 630 million per year, respectively, which would be equivalent to approximately $0.05 \%$ of total federal tax revenue. As a comparison, the total federal revenue obtained in 2018 from CIDE-fuels was USD 16.7 billion, which corresponds to $0.23 \%$ of total federal tax revenue.

To avoid an increase of the burden on taxpayers, if every dollar is returned to Brazilian households in a lump-sum transfer, high-income households would receive USD 103 million - approximately $0.02 \%$ of their total expenditure-, while low-income households would receive USD 64 million - equivalent to $0.07 \%$ of their total expenditure, respectively. Therefore, due to the regressive effects of the policy, a carbon tax scheme should be followed by a compensation policy, such as a direct transfer, which could offset the negative impacts of the tax on poorer households. Given the complexity of the Brazilian tax system - with over 80 different taxes and other fiscal levies at the federal, state and municipal levels -, together with the high tax burden - 33\% of gross domestic product (GDP), the second dividend effect could occur in a context in which the carbon tax is implemented under a broader tax reform.

\subsubsection{Sensitivity analysis}

If a carbon tax is implemented as a discretionary policy, levied only on groups of products with high carbon footprint - such as commuting and transportation and food and beverages -, the environmental impact would be positive, but much smaller in magnitude, as presented in Table 2.10 and Table 2.11 (Appendix).

Following this design, total carbon emissions are expected to decline by $0.4 \%$ and $0.9 \%$ with a carbon tax of USD $40 / \mathrm{tCO}_{2} \mathrm{e}$, and $0.9 \%$ and $1.7 \%$ for USD $80 / \mathrm{tCO}_{2} \mathrm{e}$ tax if it is levied on commuting and transportation and on food and beverage goods and services, respectively. Despite representing a small change of the share of total 
household expenditures, the economic inefficiencies, as well as welfare losses, would be relatively higher in magnitude in the scenario in which only food and beverages are taxed based on their carbon content, especially for poorer households. In order to preserve revenue-neutrality, the government should transfer approximately USD 63 million and USD 1.8 million to high and low income households, respectively, if a hypothetical carbon tax is levied only on commuting and transportation services, and USD 70 million and USD 63.3 million for a carbon tax applied to food and beverages, respectively. These results suggest that implementing a carbon tax for targeted products, based on their carbon content, is less regressive than an economy-wide carbon tax.

\subsection{Conclusions and Policy Implications}

As part of the Paris Agreement, Brazil assumed, through its NDC, a commitment to reduce GHG emissions by $37 \%$ below 2005 levels in 2025 and subsequently by $43 \%$ below 2005 levels in 2030. We analyze the effectiveness of implementing an economywide carbon tax as an option among carbon pricing mechanisms, given that a tax system reform is a top-priority for the current Brazilian government and Brazil's NDC should be revised in 2020, document that is not clear about which instruments might be adopted by the country to reach its 2030 goals.

Notwithstanding the attractiveness of a carbon tax policy to sustain mid-term environmental targets, potential distributional issues are relevant from the normative perspective since they can affect the acceptability of the policy and put a question mark on its overall effectiveness. Within a partial equilibrium framework, our analysis offers a detailed assessment of the distributional short-term welfare and emission effects of a hypothetical carbon tax in Brazil.

Our findings suggest that the first dividend could be observed in the Brazilian context: at the benchmark levels of USD $40 / \mathrm{tCO}_{2} \mathrm{e}$ and USD $80 / \mathrm{tCO}_{2} \mathrm{e}$, a carbon tax can be efficient in providing an improvement in the environmental conditions, as it reduces overall GHG emissions by $2.1 \%$ and $4.2 \%$, respectively. However, evidence indicates that a carbon tax tends to be regressive by causing welfare losses of $0.06 \%$ and $0.10 \%$ in relation to total expenditures for richest and poorest households, respectively. Low-income households are less price-responsive for the majority of carbon intensive categories, so they suffer a larger relative welfare loss due to the carbon tax. They are also more likely to suffer from a larger relative indirect effect of food and beverages 
and housing-related consumption, which accounts for a greater budget share of these households. Significant changes in total GHG emissions would require a higher tax rate, which would reinforce the regressiveness of the policy.

The sensitivity analysis also shows that implementing a discretionary carbon tax policy by narrowing the tax base and focusing only on products with high carbon content (commuting and transportation and food and beverages) could reduce the regressiveness of the carbon tax. Despite that, the reductions in overall emissions would be equivalent to $22 \%$ and $41 \%$, respectively, of the total reduction in GHG emissions with an economy-wide carbon tax.

The findings indicate that compensation strategies, such a direct lump-sum transfer, need to be considered by the government to reduce the burden imposed on these households. Brazil already has one of the heaviest tax burden among developing countries (around 33\% of the GDP), which is close to the average of the countries comprising the Organisation for Economic Cooperation and Development (OECD). Unlike developed economies, however, the Brazilian burden is more concentrated in indirect and regressive taxes, as opposed to direct and progressive ones. Implementing a carbon tax within the current regulatory framework, which already generates distortions, would worsen the overall regressivity of the Brazilian tax system. In this sense, the generation of the second dividend effect could be observed only if the country implements this carbon pricing mechanism as part of a broader structural tax reform, following examples such as Argentina, Mexico and Colombia.

A few caveats deserve attention, which could be explored by future studies. First, we assume that the changes in energy prices from a carbon tax are fully passed through to consumers. Carbon pricing may change real wages and returns to capital, which can influence the optimal input production (and hence emissions) for various sectors. Second, our analysis focuses only on the cost of the policy; and direct burden is only one channel through which a climate policy has distributional effects. If lowincome households obtain more gains from co-benefits of the carbon tax, the 'net' incidence of the policy may actually be progressive. Likewise, if wealthier households have comparatively more benefits, the 'net' incidence may be even more regressive. Third, despite considering an economy-wide carbon tax, one which takes into account all emissions, actual carbon pricing mechanisms often have exemptions for emissions from some industries due to political considerations or high monitoring costs. Fourth, because we do not observe prices and quantities for all products included in the Brazilian household expenditure survey, our short-term elasticity estimates might be 
underestimated for several consumption groups. A suggestion for the next POF for IBGE to disclose the prices of the products used in the calculation of the consumer price index for the period in which the survey is carried out. This would improve the accuracy of future studies investigating consumer behavior patterns. 


\section{APPENDIX}

\section{A Tables and Figures}

Figure 2.1 - $\mathrm{CO}_{2} \mathrm{e}$ Emission Coefficient $\left(\mathrm{tCO}_{2} \mathrm{e} / \mathrm{USD}\right.$ million 2019)

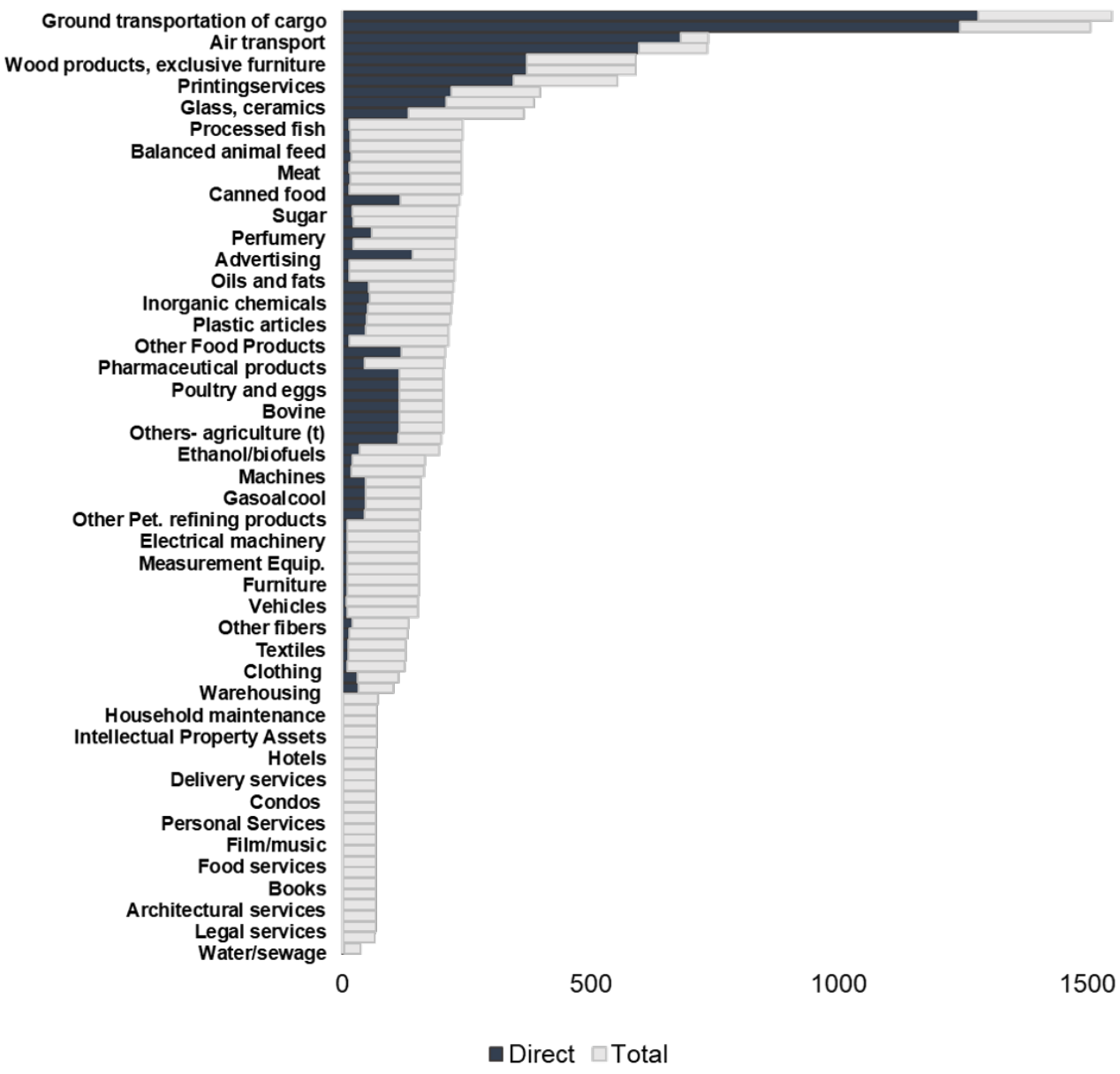

Note: This figure presents the estimates for the direct and indirect emission coefficients for the goods and services consumed by Brazilian households, presented in decreasing order of relative $\mathrm{CO}_{2} \mathrm{e}$ emissions. 
Table 2.1 - Description of expenditure groups

\begin{tabular}{l|c}
\hline Groups & Items \\
\hline 1 Food and beverages & Food, beverages, catering \\
2 Recreation, culture/education & Private education, arts, books, hotels \\
3 Clothing/footwear & Clothes, shoes, fabrics, textiles \\
4 Commuting/transportation & Air, water and ground transportation \\
5 Health/hygiene & Pharmaceutical products, private health \\
6 Energy & Electricity, gas, gasoline, ethanol, diesel, charcoal \\
7 Housing & Residential appliances, rent, water and sewage \\
8 Other goods & Plastic, ceramic, wood and paper articles \\
9 Other services & Public and other administrative services \\
\hline
\end{tabular}

Note: This table presents the 9 consumption groups used in the demand system estimation, and it covers the total household consumption basket. Residential appliances include equipment such as stoves, washing machines, refrigerators, televisions, vacuum cleaners, electric ovens, electric irons, TVs, air conditioners, fans, computers, microwave ovens and clothes dryer. We are not able to split electricity from gas since these products are aggregated on the SUTs. 
Table 2.2 - Positive consumption and budget shares by group/ income level (\%) $(\mathrm{mean} / \mathrm{sd})$

\begin{tabular}{|c|c|c|c|c|c|c|}
\hline \multirow{2}{*}{ Groups } & \multicolumn{3}{|c|}{$\%$ of positive consumption } & \multicolumn{3}{|c|}{ Budget share } \\
\hline & $\begin{array}{l}\text { All } \\
\text { sample }\end{array}$ & $\begin{array}{l}20 \% \\
\text { richiest }\end{array}$ & $\begin{array}{l}20 \% \\
\text { poorest }\end{array}$ & $\begin{array}{l}\text { All } \\
\text { sample }\end{array}$ & $\begin{array}{l}20 \% \\
\text { richiest }\end{array}$ & $\begin{array}{l}20 \% \\
\text { poorest }\end{array}$ \\
\hline Food/Bev. & $89 \%$ & $80 \%$ & $94 \%$ & $\begin{array}{c}25.8 \% \\
(23.0 \%)\end{array}$ & $\begin{array}{c}15.7 \% \\
(15.1 \%)\end{array}$ & $\begin{array}{c}37.0 \% \\
(26.7 \%)\end{array}$ \\
\hline Rec./Educ. & $20 \%$ & $40 \%$ & $11 \%$ & $\begin{array}{c}4.1 \% \\
(2.4 \%)\end{array}$ & $\begin{array}{l}10.5 \% \\
(8.5 \%)\end{array}$ & $\begin{array}{c}1.0 \% \\
(0.9 \%)\end{array}$ \\
\hline Cloth./Foot. & $77 \%$ & $79 \%$ & $63 \%$ & $\begin{array}{c}3.8 \% \\
(3.7 \%)\end{array}$ & $\begin{array}{c}3.2 \% \\
(1.8 \%)\end{array}$ & $\begin{array}{c}3.1 \% \\
(2.4 \%)\end{array}$ \\
\hline Com./Transp. & $37 \%$ & $38 \%$ & $21 \%$ & $\begin{array}{c}7.3 \% \\
(6.4 \%)\end{array}$ & $\begin{array}{c}12.9 \% \\
(12.1 \%)\end{array}$ & $\begin{array}{c}3.7 \% \\
(3.4 \%)\end{array}$ \\
\hline Health/Hyg. & $18 \%$ & $46 \%$ & $17 \%$ & $\begin{array}{c}9.5 \% \\
(9.4 \%)\end{array}$ & $\begin{array}{c}7.6 \% \\
(5.9 \%)\end{array}$ & $\begin{array}{c}11.8 \% \\
(10.0 \%)\end{array}$ \\
\hline Energy & $65 \%$ & $78 \%$ & $41 \%$ & $\begin{array}{l}14.4 \% \\
(9.1 \%)\end{array}$ & $\begin{array}{c}21.7 \% \\
(19.5 \%)\end{array}$ & $\begin{array}{c}9.3 \% \\
(6.8 \%)\end{array}$ \\
\hline Housing & $85 \%$ & $91 \%$ & $79 \%$ & $\begin{array}{c}14.8 \% \\
(14.2 \%)\end{array}$ & $\begin{array}{c}16.3 \% \\
(13.0 \%)\end{array}$ & $\begin{array}{l}12.8 \% \\
(5.8 \%)\end{array}$ \\
\hline Oth.goods & $76 \%$ & $47 \%$ & $84 \%$ & $\begin{array}{c}12.3 \% \\
(11.7 \%)\end{array}$ & $\begin{array}{c}6.0 \% \\
(3.0 \%)\end{array}$ & $\begin{array}{c}18.0 \% \\
(15.0 \%)\end{array}$ \\
\hline Oth.services & $30 \%$ & $42 \%$ & $19 \%$ & $\begin{array}{c}3.2 \% \\
(2.9 \%)\end{array}$ & $\begin{array}{c}6.1 \% \\
(5.9 \%)\end{array}$ & $\begin{array}{c}1.3 \% \\
(0.6 \%)\end{array}$ \\
\hline
\end{tabular}

Note: This table shows the descriptive statistics of budget shares (in 2019 USD), positive consumption for each of the nine groups and income levels. Income deciles are constructed based on total household monetary and non-monetary income reported by POF. Other goods contain rubber, plastic, ceramic goods, non-metallic minerals, inorganic chemicals. Other services include development of systems and other information services, private and public administrative services. 
Table 2.3 - Summary statistics: socioeconomic characteristics (mean/(sd))

\begin{tabular}{|c|c|c|c|}
\hline Variables & $\begin{array}{c}\text { All } \\
\text { sample }\end{array}$ & $\begin{array}{l}20 \% \\
\text { richiest }\end{array}$ & $\begin{array}{l}20 \% \\
\text { poorest }\end{array}$ \\
\hline Education - household head (years) & $\begin{array}{c}7.4 \\
(0.03)\end{array}$ & $\begin{array}{c}10.6 \\
(0.07)\end{array}$ & $\begin{array}{c}5.9 \\
(0.03)\end{array}$ \\
\hline Age - household head (years) & $\begin{array}{c}47.6 \\
(0.15)\end{array}$ & $\begin{array}{c}49.1 \\
(0.24)\end{array}$ & $\begin{array}{c}42.6 \\
(0.21)\end{array}$ \\
\hline Female headed households (\%) & $\begin{array}{c}31.5 \\
(46.4)\end{array}$ & $\begin{array}{c}25.9 \\
(43.8)\end{array}$ & $\begin{array}{c}36.9 \\
(48.2)\end{array}$ \\
\hline Bathrooms (Number) & $\begin{array}{c}1.3 \\
(0.01)\end{array}$ & $\begin{array}{c}2.8 \\
(0.02)\end{array}$ & $\begin{array}{c}1.1 \\
(0.01)\end{array}$ \\
\hline Rooms (Number) & $\begin{array}{c}3.3 \\
(0.00)\end{array}$ & $\begin{array}{c}7.5 \\
(0.02)\end{array}$ & $\begin{array}{c}3.1 \\
(0.00)\end{array}$ \\
\hline People in the household (Number) & $\begin{array}{c}3.4 \\
(1.73)\end{array}$ & $\begin{array}{c}3.5 \\
(1.50)\end{array}$ & $\begin{array}{c}3.1 \\
(1.80)\end{array}$ \\
\hline Home ownership (\%) & $\begin{array}{c}69.5 \\
(45.9)\end{array}$ & $\begin{array}{c}73.0 \\
(44.3)\end{array}$ & $\begin{array}{c}65.7 \\
(47.4)\end{array}$ \\
\hline Total earnings(USD 2019/per capita/year) & $\begin{array}{c}15,304 \\
(14,275)\end{array}$ & $\begin{array}{c}46,492 \\
(41,419)\end{array}$ & $\begin{array}{c}3,335 \\
(1,117)\end{array}$ \\
\hline Dis. income (USD 2019/per capita/year) & $\begin{array}{c}6,185 \\
(3,909)\end{array}$ & $\begin{array}{c}15,887 \\
(9,702)\end{array}$ & $\begin{array}{l}1,468 \\
(553)\end{array}$ \\
\hline Car ownership (\%) & $\begin{array}{c}27.7 \\
(44.7)\end{array}$ & $\begin{array}{c}76.3 \\
(42.5)\end{array}$ & $\begin{array}{c}5.3 \\
(22.3)\end{array}$ \\
\hline Moto ownership (\%) & $\begin{array}{c}16.2 \\
(36.8)\end{array}$ & $\begin{array}{c}20.9 \\
(40.6)\end{array}$ & $\begin{array}{c}10.0 \\
(30.0)\end{array}$ \\
\hline Electricity (\%) & $\begin{array}{c}97.0 \\
(17.0)\end{array}$ & $\begin{array}{l}99.5 \\
(6.9)\end{array}$ & $\begin{array}{c}93.4 \\
(24.8)\end{array}$ \\
\hline Residential appliances (Number) & $\begin{array}{c}8.0 \\
(4.0)\end{array}$ & $\begin{array}{l}13.0 \\
(6.0)\end{array}$ & $\begin{array}{c}5.0 \\
(2.0)\end{array}$ \\
\hline
\end{tabular}

Note: This table presents the descriptive statistics for control variables according to income-level of socioeconomic variables used in the demand system. Residential appliances include stoves, freezers, refrigerators, vacuum cleaners, electric ovens, electric irons, washing machines, color TVs, black and white TVs, sound systems, radios, air conditioners, fans, computers, microwaves, DVD player, clothes dryers and washing machines. Income deciles are constructed based on total household monetary and non-monetary income reported by POF. Monetary values were converted to USD 2019 using the average exchange rate for that year from the Central Bank of Brazil. Disp. income = disposable income. 
Table 2.4 - Price Indices by group and income level (in USD 2019 values) $($ Mean $/(\mathrm{sd}))$

\begin{tabular}{lccc}
\hline \multicolumn{1}{c}{ Variables } & $\begin{array}{l}\text { All } \\
\text { sample }\end{array}$ & $\begin{array}{l}20 \% \\
\text { richiest }\end{array}$ & $\begin{array}{l}20 \% \\
\text { poorest }\end{array}$ \\
\hline Food/Bev. (USD/Kg) & 9.48 & 11.22 & 8.39 \\
& $(0.06)$ & $(0.23)$ & $(0.06)$ \\
Rec./Educ (USD/service) & 250.46 & 428.40 & 163.14 \\
& $(1.99)$ & $(6.80)$ & $(1.54)$ \\
Cloth./Foot (USD/item) & 31.39 & 38.27 & 27.47 \\
& $(0.12)$ & $(0.39)$ & $(0.15)$ \\
Com./Transp. (USD/service) & 512.05 & 694.08 & 390.82 \\
& $(3.58)$ & $(11.13)$ & $(3.61)$ \\
Health/Hyg. (USD/service) & 9.94 & 14.22 & 7.48 \\
& $(0.09)$ & $(0.37)$ & $(0.04)$ \\
Energy (USD/KWh,L) & 15.93 & 20.55 & 12.89 \\
& $(0.09)$ & $(0.31)$ & $(0.11)$ \\
Housing (USD/service) & 172.41 & 242.35 & 134.76 \\
& $(1.32)$ & $(4.57)$ & $(1.22)$ \\
Oth. goods (USD/item) & 55.10 & 83.96 & 38.23 \\
& $(0.63)$ & $(2.03)$ & $(0.53)$ \\
Oth. services (USD/service) & 117.10 & 191.42 & 72.60 \\
& $(0.92)$ & $(2.94)$ & $(0.98)$ \\
\hline
\end{tabular}

Note: This table presents price indices by group and income level, converted to USD 2019 using the average exchange rate for that year from the Central Bank of Brazil. They should be interpreted as relative price indexes. Income deciles are constructed based on total household monetary and non-monetary income reported by POF. Other goods contain rubber, plastic, ceramic goods, non-metallic minerals, inorganic chemicals. Other services include development of systems and other information services, private and public administrative services.

Table 2.5 - Total $\mathrm{CO}_{2}$ e emission $\left(\mathrm{tCO}_{2} \mathrm{e} / \mathrm{hh} /\right.$ year, in 2019 values)

\begin{tabular}{lccc}
\hline \multicolumn{1}{c}{ Groups } & $\begin{array}{l}\text { All } \\
\text { sample }\end{array}$ & $\begin{array}{l}20 \% \\
\text { richiest }\end{array}$ & $\begin{array}{c}20 \% \\
\text { poorest }\end{array}$ \\
\hline Food/Beverages & 3.3 & 6.0 & 0.4 \\
Recreation/education & 1.6 & 3.1 & 0.0 \\
Clothing/footwear & 0.3 & 0.8 & 0.1 \\
Commuting/Transportation & 2.0 & 8.0 & 0.1 \\
Health/Hygiene & 0.6 & 1.8 & 0.2 \\
Energy & 1.2 & 3.0 & 0.3 \\
Housing & 0.6 & 1.3 & 0.3 \\
Other goods & 0.6 & 2.0 & 0.3 \\
Other services & 0.2 & 0.1 & 0.0 \\
\hline Total & 10.5 & 26.1 & 1.7 \\
\hline
\end{tabular}

Note: Note: This table presents the $\mathrm{CO} 2{ }_{2} \mathrm{e}$ coefficient estimates, in 2019 values, based on data from SUTs (2010) and the Brazilian Energy Mix (2010). Monetary values were converted to USD 2019 using the average exchange rate for that year from the Central Bank of Brazil. 


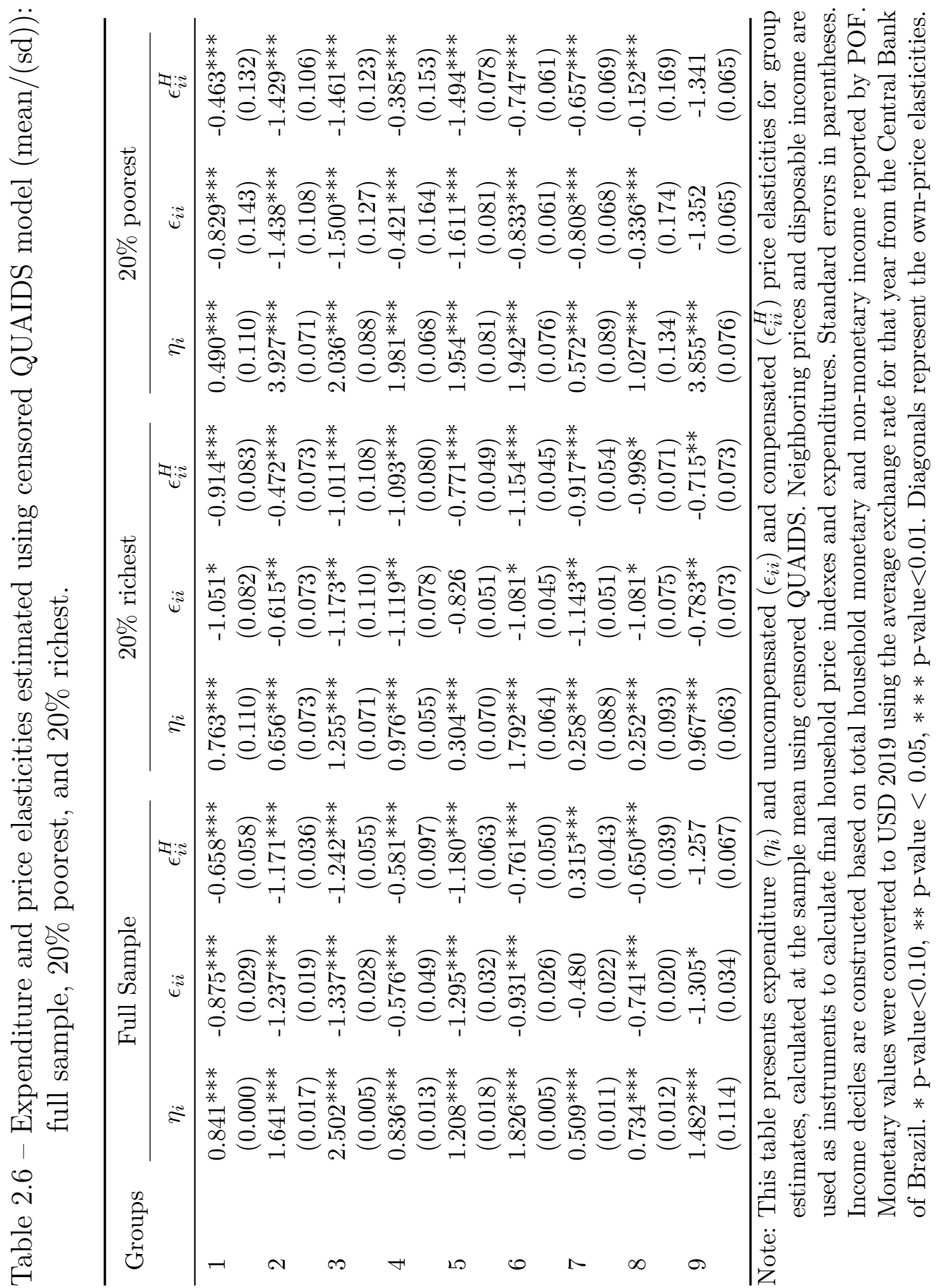




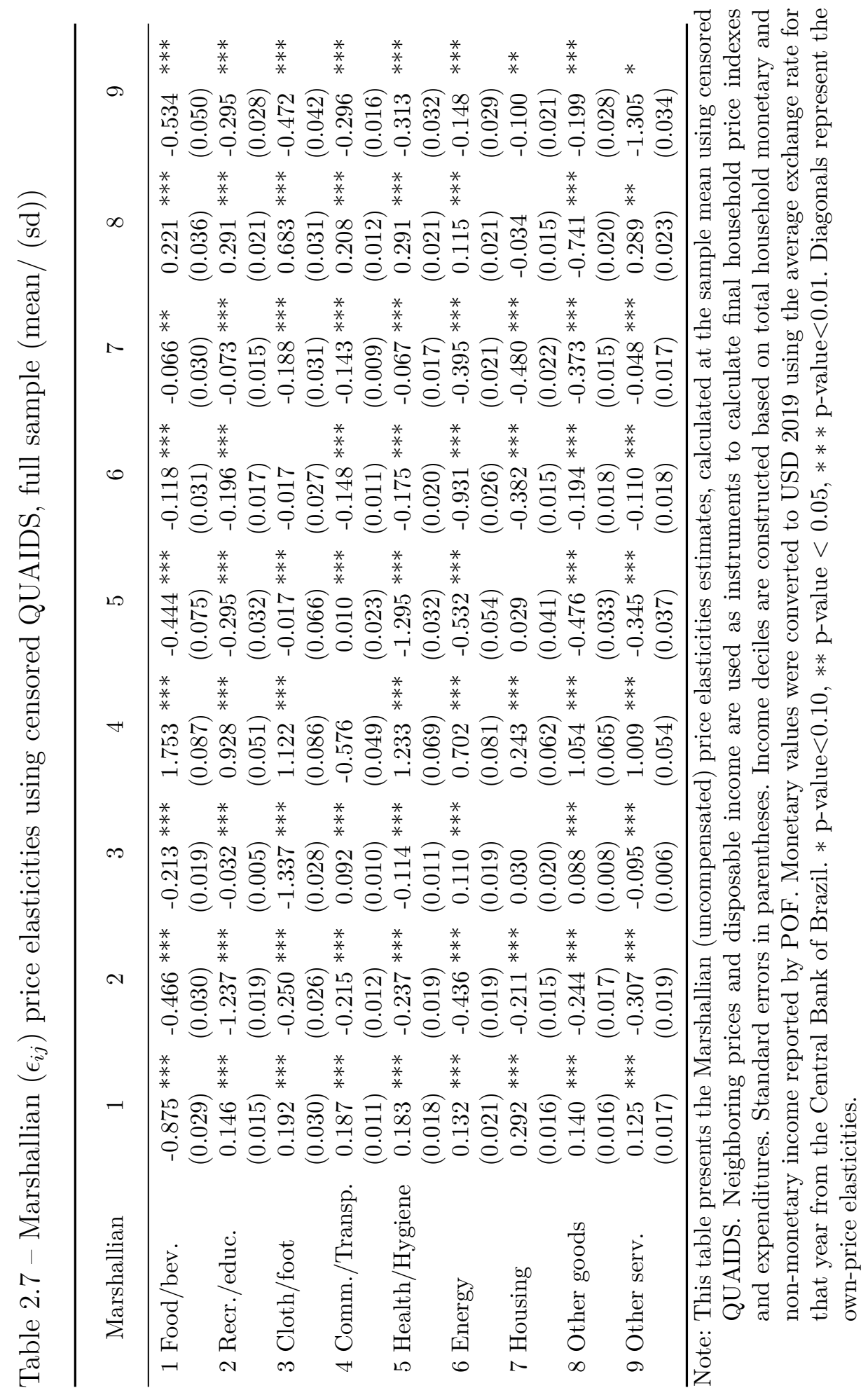




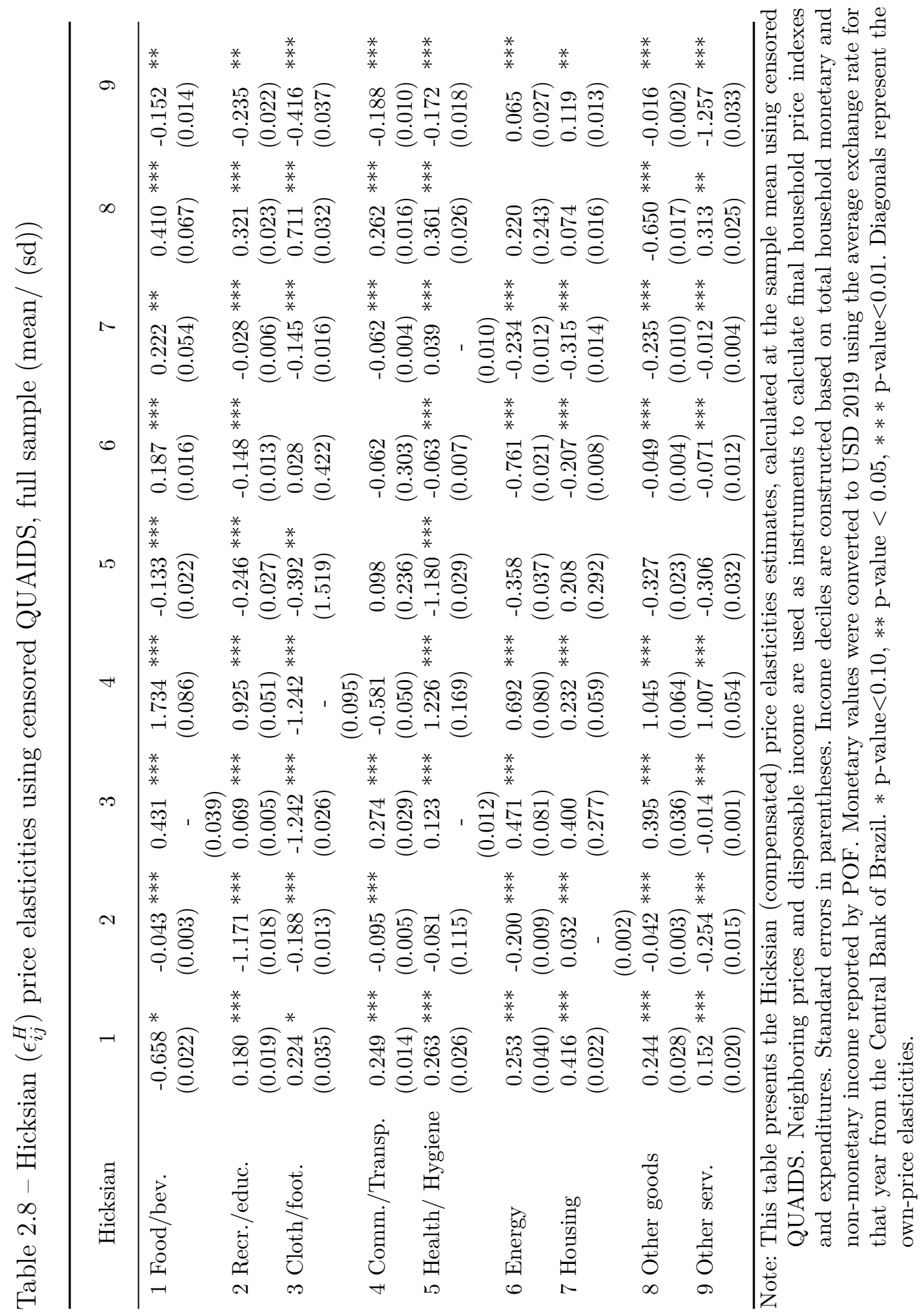




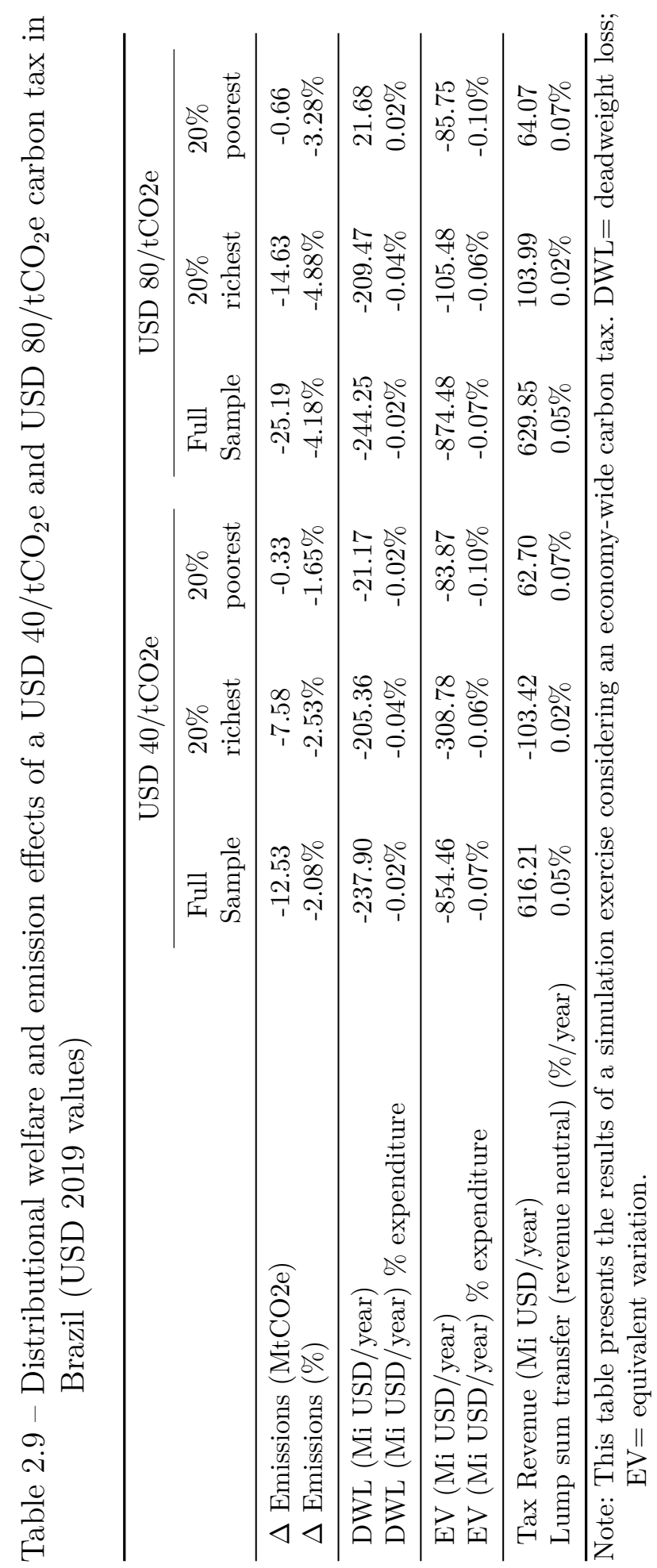




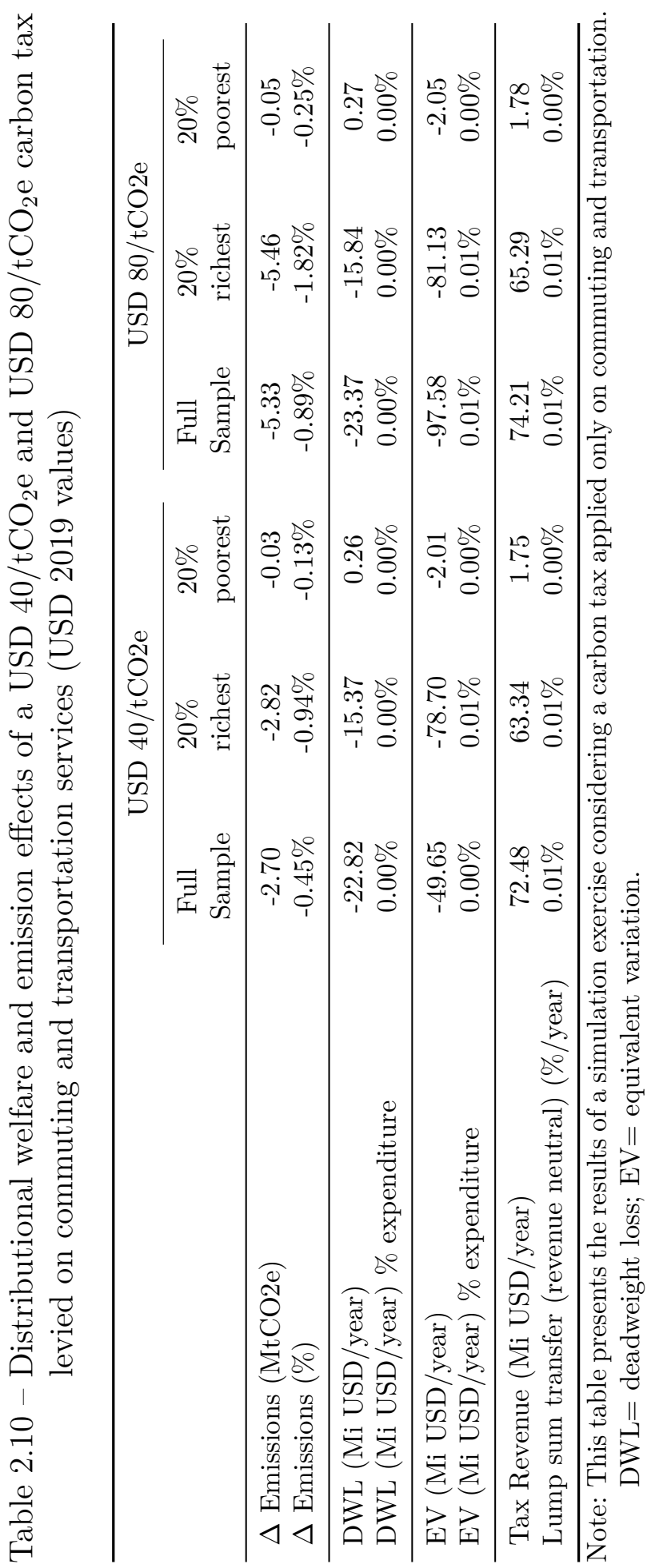




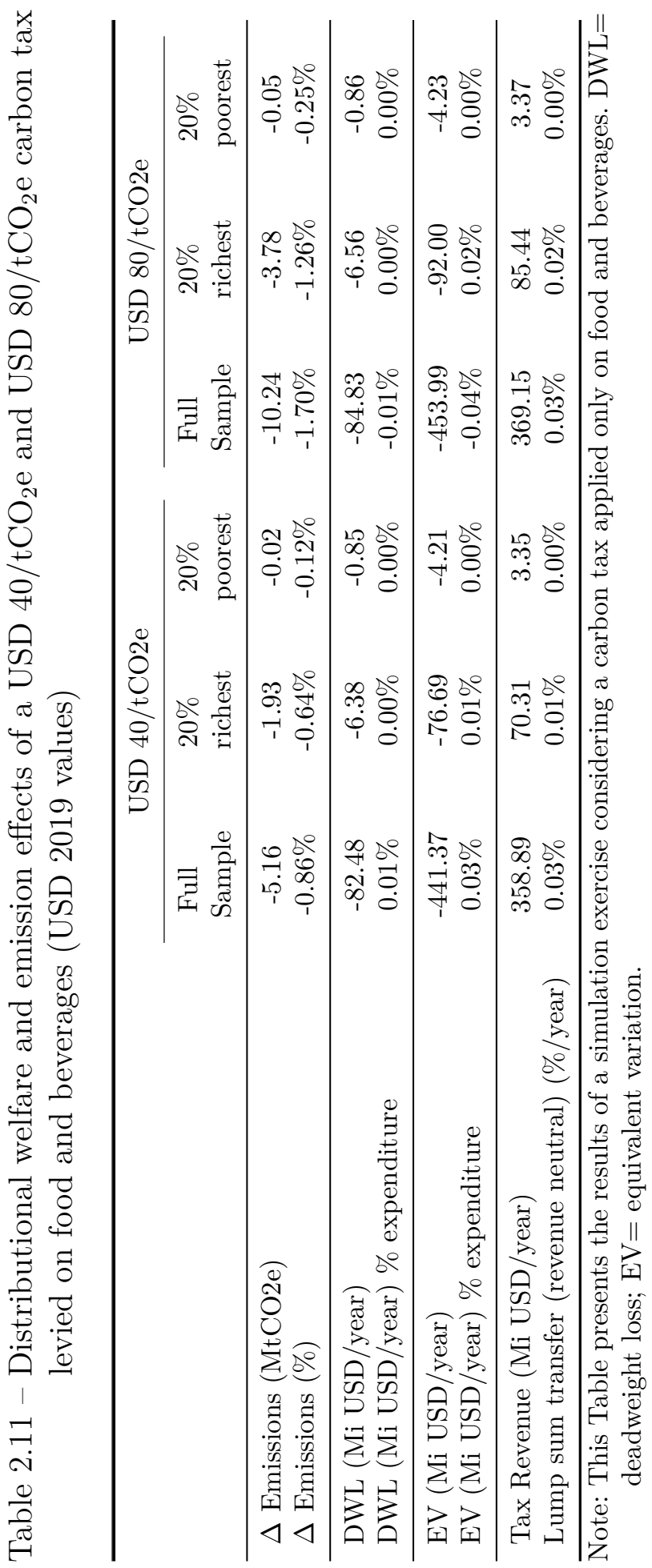





\section{Chapter 3}

\section{DOES DECENTRALIZED AND VOLUNTARY COMMITMENT REDUCE DEFORESTATION? THE EFFECTS OF PROGRAMA MUNICÍPIOS VERDES}

\subsection{Introduction}

Tropical deforestation is the third largest source of greenhouse gas (GHG) emissions and contributed to $10 \%$ (approximately 4.8 gigatonnes of $\mathrm{CO}_{2}$ ) of annual global emissions in 2017 (Wolosin and Harris, 2018). Slowing or stopping deforestation and forest degradation activities in the tropics is of crucial importance to achieve the targets under the Paris Agreements, since in all Nationally Determined Contributions (NDC) forests represent a quarter of all planned emission reductions by 2030 (Zarin et al., 2016).

Brazil, together with Indonesia, accounts for less than half of global carbon emissions from gross tropical deforestation (Hansen et al., 2013), and approximately one-third of its total $\mathrm{CO}_{2}$ emissions between 2005 and 2018 took place in the Amazon region (SEEG, 2019), which comprises $49 \%$ of Brazil's territory. This corresponds to approximately 646 million tons of $\mathrm{CO}_{2}$ released due to an average deforestation rate of $8,772 \mathrm{~km}^{2} /$ year(SEEG, 2019; INPE, 2019). Beyond the benefits to global biodiversity (Barlow et al., 2007), water cycling (Nobre et al., 2016), aboveground carbon storage and climate regulation (Baccini et al., 2017), the conservation of the Amazon forest could provide up to USD 5 trillion of economic benefits (Pindyck, 2019).

Protection of the rainforest has become a central concern in many federal and state level initiatives over the past decades. The Action Plan for the Prevention and Control of Deforestation in the Legal Amazon (PPCDAm), launched in 2004, comprised hundreds of actions organized in the areas of land titling, monitoring and control, and supporting sustainable production. This top-down effort enjoyed significant success in curbing illegal deforestation, but rising prices for agricultural commodities increased the incentive for farmers to clear forests for production. At the end of 2007, the federal 
government tried a new strategy that aimed to fix the problem at the local level by pressuring municipalities to enforce national priorities. Enabled by a presidential decree $^{3.1}$, the Ministry of the Environment (MMA) placed 43 municipalities on a list for special enforcement efforts due to historically high deforestation rates - 13 of them in Pará (Assunção et al., 2015), the state in Brazil with the highest rates of forest loss during the 2000s.

As a consequence of the blacklist, the Brazilian environmental enforcement agency (IBAMA), together with the Federal Police and the Army implemented Operation Arc of Fire (Operação Arco de Fogo $)^{3.2}$ in these municipalities, forcing the closure of illegal logging camps, interdiction of private properties and municipal access restrictions to credit.

The severe economic consequences of the operation was essential to motivate local governments to react. Pará was the only state in the Amazon to promote a decentralized strategy to support the delisting of municipalities ${ }^{3.3}$, the Green Municipalities Programme (PMV) in 2011, whose foundations mainly involve local pacts and partnerships. Municipalities adhere voluntarily to the programme and receive advantages such as legal certainty - as compliance with environmental laws reduces the possibility of sanctions such as fines or economic embargoes-, priority access to credit and rural technical assistance. In contrast, municipal governments have to convince the owners of $80 \%$ of privately held land to register their property, map property boundaries and declare the extent of deforestation in order to maintain the annual deforestation rate below $40 \mathrm{~km}^{2}$. These requirements are translated into an administrative consent decree called Conduct Adjustment Agreement (TAC), which is signed by the municipal government and the Federal Prosecution Service (MPF).

Therefore, the PMV can be understood as a territorial policy which greatly impacts on the legalization of land, as it relaxes laws combating land grabbing, facilitating land use regularization on the grounds of solving environmental problems. It is also a command, control and regulatory land policy, which is carried out through an agreement established between stakeholders at the three levels of power: federal, state

\footnotetext{
${ }^{3.1}$ Decree 6.321/07.

${ }^{3.2}$ This operation was considered a major effort to combat deforestation. It aimed at the illegal connections of several formally legal businesses, with the intent to disrupt supply chains that linked legal and illegal parts. Businesses were closed, lumber was seized, managers and owners were arrested, and charcoal furnaces were destroyed. Although the operation was not something new, it was very broad and sent an unprecedentedly strong signal of more fierce enforcement (Abranches, 2014).

${ }^{3.3}$ Between 2005 and 2009, Pará had the worse economic performance of the North region: $2.9 \%$ annual growth rate compared to $4.5 \%$ of other northern Brazilian states.
} 
and municipal (Whately and Campanili, 2013).

This paper aims to assess the PMV's effectiveness in reducing municipalities' deforestation levels. We use a high-resolution spatial dataset ( $1 \mathrm{~km}^{2}$ grid cells) containing information on forest cover for 1,781,122 pixels, equivalent to an area of 162,242 $\mathrm{km}^{23.4}$ and a nonparametric spatial regression discontinuity (RD), allowing us to compare forest cover rates within and outside the state. We expect that advantages provided by the programme - such as higher legal security and access to credit-, contribute to reducing deforestation and, therefore maintain higher levels of forest cover. Then, we use the RD estimates to calculate the avoided carbon emissions from not deforesting, and the monetary benefits of protecting the forest.

Our findings indicate that PMV municipalities managed to reduce deforestation only in the latest stages of the programme, with estimated coefficients oscillating between 0.8 and 1.2 ha/year within the optimal bandwidth. However, this effect comes mainly from municipalities with lower deforestation pressure. These estimates are robust to different specifications and bandwidth selections. Placebo regression and robustness checks controlling for unobservable heterogeneity confirm that these effects are concentrated around the areas which are less vulnerable to deforestation. Evidence suggest avoidance of roughly 8.0 $\mathrm{MtCO}_{2} /$ year released to the atmosphere. The extrapolation of our estimates to the total area that could be legally deforested in Pará indicates the PMV could have prevented $41 \%$ of deforestation in the Amazon region between 2015 and 2018.

This paper relates to the empirical literature that uses national and sub-national borders to evaluate the effects of environmental policy across space ${ }^{3.5}$ and studies that investigate the impacts of decentralized forest management initiatives on deforestation

\footnotetext{
${ }^{3.4}$ Equivalent to the combined area of Portugal and Ireland.

${ }^{3.5}$ For the Brazilian Amazon, Burgess et al. (2019) assess the role played by national policies as a determinant of deforestation in the Amazon region and show that, compared to neighbouring countries, Brazilian policies were effective in reducing deforestation levels. Anderson et al. (2016) focus on the implementation of conservation zones, providing evidence that zones cannot explain the large reduction in deforestation rates, as they were typically placed in areas where deforestation most likely would be unprofitable also in the absence of a zone. Bonilla-Mejía and Higuera-Mendieta (2019) analyse the implementation of protected areas in the Colombian Amazon, finding that deforestation has decreased significantly in these areas, with larger effects for collective lands than strict-use protected areas. Using tree cover loss data for 14 contiguous countries in Africa, Asia and Latin America, Cuaresma and Heger (2019) identify the existence of an environmental Kuznets curve for forest cover, with high rates of forest cover loss as low income countries develop economically, no significant forest cover changes as middle income countries develop economically, and also no significant changes as high income economies keep on growing.
} 
in low- and middle-income countries ${ }^{3.6}$. To the best of our knowledge, this is the first study that uses high-resolution spatial data to assess the impact of a decentralized and voluntary environmental programme, focusing on the heterogeneity of effects through time. The PMV has been previously investigated by Santos et al. (2016), who found that municipalities were not effective in reducing deforestation compared to non-participants. However, the authors focused on municipal-level data for the 2010-2013 period, and therefore, did not account for spatial and long-term effects.

The remainder of this paper is organized as follows. Section 3.2 presents an overview of the PMV background and evolution. Section 3.3 details our empirical strategy, dataset and main variables. Section 3.4 discusses the results and 3.5 describes robustness checks. Section 3.6 presents conclusions and policy implications.

\subsection{The Green Municipalities Program (PMV)}

The state of Pará is located in northern Brazil and crossed by the lower Amazon River. It borders the states of Amapá, Maranhão, Tocantins, Mato Grosso, Amazonas and Roraima. To the northwest are the borders with Guyana and Suriname, and to the northeast is the Atlantic Ocean (See Figure 3.1, Appendix). It covers a total area of $1,247,954 \mathrm{~km}^{2}$ - the equivalent of the combined area of Portugal, Spain and France -, out of which 888,400 $\mathrm{km}^{2}$ was forests in 2008 (Almeida et al., 2016). The state is divided into 144 municipalities, with an average size of approximately 8,666 $\mathrm{km}^{2}$.

Historically, Pará tops the list of the Brazilian states with the highest deforestation rates - being responsible for approximately $40 \%$ of total Amazon deforestation (see Figure 3.2, Appendix). One of the major causes of the persistence of deforestation is the territorial and economic model of occupation that predominates in the state, based on timber harvesting, agriculture and ranching, which leads to a "boom-bust" economy:

\footnotetext{
${ }^{3.6}$ Andersson and Gibson (2007) assess the effect of forestry policy decentralization on deforestation between 1993 and 2000 in 30 Bolivian municipalities. The authors use two-stage least square regressions, without any counterfactual analysis to determine the impact on deforestation from decentralization. They find that municipal-level institutions are effective to contain illegal deforestation: forest cover improved $0.8 \%$ over what the rate would be in the absence of the programme in areas where cutting is not permitted. Baland et al. (2010) use outcome data from an on-the-ground survey administered in 83 Indian villages and fixed effects model, and find that forest degradation (proxied by logging) improved $0.4 \%$ over what would be the case otherwise in community-managed areas. This suggests that the effects of decentralized management may take a long time to materialize themselves, and can exhibit considerable heterogeneity across regions. Miteva et al. (2012) summarize evidence of the effectiveness of decentralization of conservation policies, and point that they need time to show effects.
} 
this means that in the first years of economic activity there is rapid and ephemeral growth (boom), followed by a severe decline in income, employment and tax collection as the natural resources are exhausted (bust) (Veríssimo and Jr., 2006). By 2012, 21\% of its territory had been altered due to deforestation (INPE, 2013).

To better target the efforts to surpress deforestation in the Amazon region, the MMA blacklisted 36 municipalities (out of 547 municipalities that transect the biome) in December 2007 as part of PPCDAm, which were responsible for $45 \%$ of the total deforestation in the region (Assunção et al., 2015). While a municipality remained on the list, its residents faced increased law enforcement scrutiny, restrictions on credit $^{3.7}$, and difficulty in selling what they $\operatorname{produced}^{3.8}$, which led to significant economic losses: from 2007 to 2008, the gross domestic product (GDP) of Pará state presented real growth of $4.9 \%$, while the blacklisted municipalities' GDP increased only $0.2 \%$ (IBGE, 2010). By passing responsibility for environmental issues and enforcement to municipal government, the blacklist created strong incentives to curb local deforestation ${ }^{3.9}$. Being removed from this list would imply loan guarantees and more open markets, as well as the possibility of carbon finance for reducing emissions from deforestation and degradation of forests (REDD+).

To reverse the situation, one of the 13 blacklisted municipalities in Pará, Paragominas, launched the "Green Municipality" project in 2008. By engaging different types of stakeholders, it aimed to achieve a "zero deforestation" rate, to enable full environmental registration of agricultural property ${ }^{3.10}$ as well as monitoring and traceability of cattle herds. In April 2010, Paragominas became the first municipality to be removed from the list for reducing local deforestation and forest degradation rates by more than $90 \%$ (Whately and Campanili, 2013) ${ }^{3.11}$.

\footnotetext{
${ }^{3.7}$ Resolution 3.545/2008 of the National Monetary Council, which has made funding for rural properties located in the Amazon Biome subject to the environmental regularisation of the property.

${ }^{3.8}$ Major Brazilian retail chains (such as Wal-Mart, Carrefour and Pão-de-Açúcar) stopped buying products obtained through illegal deforestation, and some meat packers (such as JBS and Marfrig) committed themselves to buying only from suppliers that are environmentally compliant.

${ }^{3.9}$ From 2009 to 2011, the PPCDAm executed 649 joint inspection operations, applied more than 7 billion reais (USD 3.1 billion) in fines, seized more than $800.000 \mathrm{~m}^{3}$ of logs and imposed embargoes on more than 600.000 hectares in the total Amazon region.

${ }^{3.10}$ Which entails georeferencing of the property, location and measurement of forest cover and riparian vegetation.

${ }^{3.11}$ It also earned access to loans and markets for its soy and beef, and opened a factory that made furniture from sustainably-harvested timber - a critical step, because it provided jobs for unemployed loggers. By mapping territory, farmers were able to identify underutilized degraded lands and increase production of soy, while cattle ranchers were able to ratchet up production by incorporating silage to feed their animals.
} 
The successful experience of Paragominas inspired the government of Pará to draft a state programme to support its other municipalities. The PMV was launched in March 2011, aiming to create a "sustainable development pact" between municipal and state governments, the Federal Prosecution Service, local business associations, non-governmental organizations ${ }^{3.12}$ and universities ${ }^{3.13}$. The overall goal is to reduce the state deforestation by $80 \%$ by 2020 compared to the annual average of $6,255 \mathrm{~km}^{2}$ (1996-2005), achieving zero net deforestation this year. It also aims at increasing by $50 \%$ the number of rural property registrations in the Rural Environmental Registry (CAR) and removing all Pará municipalities from the MMA list.

Since the PMV is a voluntary programme, the municipal government needs first to sign the TAC with the Federal Prosecution Service, to provide legal and political stability for the program. It is an extrajudicial instrument ${ }^{3.14}$ and indicates that the municipality is committed to a set of goals: (i) to sign a local pact against deforestation; (ii) to carry out field verification of deforestation points and report them to the PMV; (iii) to maintain an annual deforestation rate below $40 \mathrm{~km}^{2}$ based on the data from the Satellite Monitoring System of the Brazilian Amazon Forest (PRODES); (iv) to register at least $80 \%$ of its total area (excluding indigenous and conservation units) in the CAR; (v) to not be part of the MMA's deforestation list; and (vi) to promote environmental education in local schools (Neves et al., 2016).

At the time of the PMV's launch, deforestation rates in Pará had already been reduced by approximately 50\% compared to 2005 levels, as shown in Figure 3.2 (Appendix), which suggests that the main goal of the programme was not ambitious. However, the challenge rested mainly in convincing farmers to conduct self-declared registrations and achieve a larger area in the CAR, as well as to keep deforestation rates below $40 \mathrm{~km}^{2}$ in each municipality.

Adherence to the PMV is encouraged by the potential benefits of participating in the programme and the consequent reduction in deforestation - such as legal security

\footnotetext{
${ }^{3.12}$ Instituto do Homem e do Meio Ambiente da Amazônia (Imazon) and The Natural Conservancy (TNC).

3.13 The PMV governance structure is mainly composed of government institutions (such as the Federal Prosecution Service, IBAMA and the Pará State Public Prosecution Service), private sector, non-governmental organizations and rural producers (mainly from the agribusiness sector). Up to 2017, there were three to four meetings a year, which were attended by official participants (who were allowed to vote) as well as an extended audience, which in some cases reached almost 300 people.

${ }^{3.14} \mathrm{By}$ signing the TAC, the municipalities pledge to take actions to prevent or stop deforestation. In case of noncompliance, the MPF may trigger the Courts to enforce the TAC. Some authorities and entities legitimized by the current set of laws may file public civil actions and/or suits.
} 
(ensuring that producers would not suffer from fines and economic embargoes), increased market value of agricultural products (such as certification guaranteeing avoided deforestation and ethical working conditions) and more investments due to greater legal security (Neves et al., 2016; Santos et al., 2016). Municipalities with high engagement in controlling deforestation and implementing environmental management can also receive higher tax revenues from the Green Tax Fund (ICMS Verde). In 2015, $\mathrm{R} \$ 82$ millions reais (USD 21 million) was transferred from the Amazon Fund to municipalities to support CAR registration as part of the programme..

The CAR plays an important role in the PMV's effectiveness through some mechanisms. First, since CAR registration is mandatory for farmers to access to rural credit, they need to report critical information about their properties' vegetation cover. Per se, this enforces care for their farms' existing original vegetation and avoidance of new deforestation. Second, small farmers would tend not to register with the CAR since the costs of completing the process are very high. This problem was mitigated by the formation of a partnership with the Norwegian government and by the action of non-governmental organizations (Whately and Campanili, 2013). Third, the detailed information given by farmers to authorities allows the identification of potential deforestation areas and take rapid measures to prevent it. By making CAR registration one of the main requirements for property regularisation ${ }^{3.15}$, the public authority has thus assumed the position that the origin of the property is not important, and as a result, has become the guarantor of illegally appropriated lands.

When joining the PMV, municipalities are classified into five categories according to their "pressure for deforestation" ${ }^{3.16}$. Municipalities can be moved to different categories as their situation improves or deteriorates. After being certified as a "green municipality", failure to continue complying with the programmes'goals causes a mu-

\footnotetext{
${ }^{3.15}$ Including dispensing the need to submit a valid title chain as proof of the legal acquisition of the land.

${ }^{3.16}$ The five categories are: i) Embargoed: municipalities which are on MMA's priority list; ii) Under pressure: municipalities with a high deforestation rate or located near major infrastructure projects that increase the risk of deforestation; iii) Consolidated: municipalities with less than $60 \%$ of vegetation cover in 2010, but lower levels of deforestation (in this category, the main goal is to improve the share of registered rural properties on the CAR and regularise environmental liabilities of farmers); iv) Forest base: municipalities with more than $60 \%$ of vegetation cover in 2010 and a low risk of deforestation, even though it still exists (since municipalities in this category have large conservation units, the main policy is to strengthen the forest economy) and v) Monitored or under control (also known as "Green Municipality"): municipalities that were removed from MMA's list and meet the requirements of Resolution 01/2012. The most notable example is Paragominas (Whately and Campanili, 2013). In principle, by adhering to the programme and meeting its goals, all municipalities would be listed in this category.
} 
nicipality to be downgraded.

At the time of the PMV's launch, 92 municipalities had signed the TAC (see embargoed municipalities in Table 3.1, Appendix), out of which 16 were part of the MMA's list.All told, these 92 municipalities represented almost $90 \%$ and $92 \%$ of total state and forest areas, respectively, while blacklisted municipalities represented $34 \%$ and $33 \%$ of the total state and forest areas, respectively (Figure 3.4, Appendix). In 2018, the programme reached 130 municipalities, covering $95 \%$ of the total state forest area. In this sense, there is an important difference between early and late participants in the programme: early-stage adherents - that is, municipalities which joined the PMV up to 2013 - were obliged to sign TACs with the MPF, while later participants - municipalities that joined the PMV in the last 5 years - just signed an agreement with the PMV coordination $^{3.17}$. This aspect suggests that municipalities may have different levels of enforcement.

Technical reports suggest that municipalities took a long time to implement the PMV's commitments: in 2012, only 20 out of the 92 municipalities had fulfilled some of the PMV goals. At the same time, 4 out of the 16 municipalities ${ }^{3.18}$ were taken off MMA's list and were released from economic sanctions and political pressures; and two new municipalities entered the list ${ }^{3.19}$, totalling 14 municipalities embargoed in the state at the end of 2012. In this respect, Santos et al. (2016) analysed the programme's impacts in its early stages (2010 and 2013) using difference-in-differences and propensity score matching approaches based on municipal-level data, finding that participants had not been effective in reducing deforestation compared to non-participants. However, land registration goals were achieved, as about half of the state's registrable area was placed in the CAR in 2012, corresponding to 31.3 million hectares distributed in 62,750 thousand properties. In 2020, the 130 participating municipalities have an average of $70 \%$ of their registrable area in the CAR, which is equivalent to 40.6 million hectares (Sicar, 2020).

\footnotetext{
${ }^{3.17}$ Exceptions are the municipalities of Abaetuba, Muaná and São João do Araguaia, which signed TACs with the MPF in 2012, 2015 and 2019, respectively. However, Abaetuba and Muaná had previous agreements with PMV coordination.

${ }^{3.18}$ Santana do Araguaia, Ulianópolis, Dom Eliseu and Paragominas.

${ }^{3.19}$ Anapu and Senador Jose Porfirio.
} 


\subsection{Empirical methods and data}

\subsubsection{Empirical strategy}

As the PMV is a state programme, it creates a quasi-experimental opportunity to assess one of its main goals - reduction of deforestation rates - by comparing the evolution of forest cover rates of treated areas (Pará municipalities which are part of the PMV) and control areas (municipalities from the neighbouring states of Amapa, Roraima, Mato Grosso, Tocantins and Maranhao). The border of Pará can be used as a clear spatial cutoff point that separates regions that are eligible to be part of the programme from those that are not. As treatment and control groups are spatially located with close proximity, they are assumed to be similar in all important aspects except for the participation in the programme (Cuaresma and Heger, 2019; Anderson et al., 2016).

Our empirical analysis uses high spatial resolution grid cells of $1 \mathrm{~km}^{2}$. We define the running variable as the minimum distance to the Pará border, and "treated" grid cells as those located within Pará and are in municipalities that belong to the PMV (positive distances), while "control" cells are located outside Pará (negative distances), within a $50 \mathrm{~km}$ range ${ }^{3.20}$. Since conservation units and indigenous lands are not part of the scope of the programme, we excluded the grid cells that belong to such areas. Grid cells that are close to the international (northwest Pará borders with Guyana and Suriname) ${ }^{3.21}$, coastline (northeast border with the Atlantic Ocean) and Cerrado Biome borders (southeast of Pará) were also discarded. Figure 3.3 D (Appendix) presents the area analysed in this study.

Our main outcome variable, remaining forest cover in grid cell $i$ and year $t$, in $\%$ or hectares, can be defined as:

$$
Y_{i t}=\frac{F C_{i t}-\sum_{t=2008}^{t} D A_{i t}}{F C_{i, 2008}}
$$

in which $F C_{i t}$ indicates the forest cover in grid cell $i$ in year $t, \sum_{t=2008}^{t} D A_{i t}$ represents the grid cell cumulative deforestation from 2008 onwards, and $F C_{i, 2008}$ is

\footnotetext{
${ }^{3.20}$ The buffer definition is per se an empirical question. We conduct robustness checks to analyse the sensitivity of the results (See section 3.5).

${ }^{3.21}$ In addition to potential institutional differences, there are no comparable deforestation data for these countries.
} 
grid cell forest cover for the baseline year, 2008.

Following Burgess et al. (2019), Cuaresma and Heger (2019) and Anderson et al. (2016), the sharp RD treatment effect can be estimated using the following equation:

$$
Y_{i t}=\alpha_{i t}+\delta \text { Pará }_{i t}+f\left(\text { DistBorder }_{i}\right)+\gamma X_{i t}+\varepsilon_{i t}
$$

Where $Y_{i t}$ is remaining forest cover in grid cell $i$ and year $t$, Pará $i t$ is a dummy equal to one if grid cell $i$ is inside Pará and part of the programme in year $t$. $f\left(\right.$ DistBorder $\left._{i}\right)$ is a polynomial of distance to Pará border, allowed to have a separate effect on each side of the border ${ }^{3.22}$ and $X_{i t}$ is a vector of geographical (slope, soil type and distance to streams) and structural controls (distance to roads, distance to municipalities and distance to IBAMA offices). These control variables come from the literature on deforestation patterns in the Amazon region (Burgess et al., 2019; Assunção et al., 2015; Anderson et al., 2016). We consider that the municipalities joined the programme in the year in which the municipal government signed the TAC, and in the absence of this information, the year in which it signed the agreement with the PMV coordination. Therefore, as there are time differences in the adherence to the programme, the above equation is estimated separately for each year in the 2010-2018 period to explore the dynamics of the effects. In addition, we also estimate Equation (1) for the 2008 - 2010 period to use as falsification tests.

The difference in the forest cover of a grid cell $i$ in year $t$ on the Pará side relative to outside its border is measured by the coefficient $\delta$, expressed in $\%$ or in hectares. For 2008 , it indicates the difference in the share of forest cover in a specific grid cell; for the period 2009-2018, it refers to the difference in the share of remaining forest cover. $\delta$ can also be understood as the local average treatment effect: as the RD restricts the treatment and control groups only to a certain bandwidth around the cutoff to ensure that they are similar on average, the treatment effect cannot be generalized to the entire population. We are, therefore, only able to estimate the local average treatment effect (LATE) (Thomas et al., 2019).

We use separate linear regression models on each side of the border ${ }^{3.23}$. Based on Cattaneo et al. (2019) and Imbens and Kalyanaraman (2012), for each year $t$, we

\footnotetext{
${ }^{3.22}$ For grid cells located exactly on the border (DistBorder $=0$ ), we matched the grid cell to the respective municipality according to the largest share of the grid cell.

${ }^{3.23}$ According to Cattaneo et al. (2019), linear models provide a good trade off between simplicity, precision and stability in nonparametric settings.
} 
estimate the local linear RD effect using triangular kernel weights and common mean squared error (MSE) optimal bandwidths. In our preferred specification, we also use robust bias correction to construct confidence intervals and clustered standard errors in blocks of $25 \mathrm{~km}^{3.24}$ using a nearest neighbour variance estimator to allow for geographic spatial error correlation (Conley, 1999; Burgess et al., 2019). Validation tests for absence of discontinuities for control variables and potential manipulation around the cutoff are presented in Section B (Appendix). Robustness checks to account for unobservable and confounding factors, as well as placebo test, are presented in Section 3.5.

\subsubsection{Spatial data construction}

\subsubsection{Spatial data}

All the spatial data were gathered from open-source repositories and official government databases. Forest cover and deforestation rates are provided by PRODES, from the National Institute for Space Research (INPE) (INPE, 2019). This system uses a combination of computer and human analysis ${ }^{3.25}$ to calculate and delimit annual forest cover and annual deforestation among the seasonal year, which starts on August 1st and goes to July 31st ${ }^{3.26}$. For the Amazon region, PRODES only maps the loss of "primary forest" cover in areas with vegetation classified as "forest" by the RADAMBRASIL project, and also clearings larger than 6.25 hectares $^{3.27}$. Because of that, forest degradation and smaller clearings are not detected, and also the deforestation in the secondary forest is ignored by the definition of the programme. PRODES data are also used by the PMV for monitoring purposes.

Spatial data for geographic - soil type, biomes, streams - and structural controls - urban agglomerations (cities, villages, capitals, urban and rural localities) and roads (official paved and unpaved) - were collected from IBGE at a scale of 1:250,000. Auxiliary data, such as conservation units, indigenous land, municipalities and states, also are provided by IBGE's continuous cartographic base. We use complementary spatial data

\footnotetext{
${ }^{3.24}$ We find almost identical results for different cluster sizes (10, 15, 30, 50 and $\left.100 \mathrm{~km}\right)$.

${ }^{3.25}$ This supervised forest classification adds more precision to the identification of forest grid cells compared to other methods - such as the one described by Hansen et al. (2013), who used an enhanced vegetation index to define forest areas.

${ }^{3.26}$ This time period allows for better image collection, since July-August is the middle of the dry season, when the forest is less likely to be covered by clouds, and is more aligned with typical clearing cycles in the region.

${ }^{3.27}$ Approximately 8 soccer fields.
} 
such as: urban agglomerations and unofficial roads provided by OpenStreetMap's API, local administrative offices of IBAMA, and slope (in degrees) derived from the digital elevation data gathered by the Shuttle Radar Topography Mission (SRTM), from

the National Aeronautics and Space Administration (NASA). Summary statistics are presented in Table 3.2 (Appendix).

\subsubsection{Dataset generation}

To create a grid cell dataset, first we delimit a $50 \mathrm{~km}$ buffer zone inside and outside Pará's borders, which corresponds to an area of $561,585 \mathrm{~km}^{2}$. We then convert this zone into grid cells of $1 \mathrm{~km}^{2}$, identified by a unique number, and their centroids are later linked to the respective municipalities. Based on this information, we construct a raster dataset with Euclidean distances (in meters) from the Pará border and we calculate the minimum distance of each grid cells to the border. This dataset is later combined with annual data on the percentage of forest cover and deforestation rate, together with conservation units, indigenous lands and data on all control variables presented previously. We associate conservation units, indigenous lands, soil type and biomes domain data for each grid cell as the feature with maximum percentage in the cell.

In particular, forest cover data for 2018 are used to eliminate overlapping features and geometry errors. Then, we update the 2018 forest cover with 2008-2018 deforestation rates with the corrected geometric and topological data. Finally, we obtain a spatial dataset of annual forest cover, annual deforestation rate and remaining annual forest cover, which are merged with the grid cell database.

A spatial filter is also applied to exclude grid cells with no information related to forest cover or deforestation rates. These areas are mainly related to international borders, coastlines, as well as areas in the Cerrado biome $\left(391,346 \mathrm{~km}^{2}\right)$. As conservation unit and indigenous lands are not part of the PMV scope, these respective grid cells are also excluded from the final dataset. The map corresponding to our restricted grid cell dataset - $100 \mathrm{~km}$ buffer zone containing 1,781,122 observations and corresponding to an area of $162,242 \mathrm{~km}^{2}$ - is presented in Figure 3.3 (Appendix). Within Pará's 50km buffer zone, we have detailed information for 38 out of the 130 participanting municipalities, covering an area of $56,700 \mathrm{~km}^{2}$ and representing $15.9 \%$ of total forest area that can be potentially deforested in Pará and $16.7 \%$ of the total forest area under the PMV. In addition, out of these 38 municipalities, 9 have higher deforestation pressures (being 
classified as "under pressure" or part of the MMA's list), comprising an area of 29,100 $\mathrm{km}^{2}$, while 29 municipalities with deforestation levels under control cover $27,600 \mathrm{~km}^{2}$.

\subsubsection{Conversion of biomass into $\mathrm{CO}_{2}$}

To compute the emissions from the avoided deforestation, we use the equation and coefficients provided by the Brazilian Ministry of Science, Technology, Innovation and Communication (MCTIC) in the Third National Inventory ${ }^{3.28}$ (BRASIL, 2015b), considering that the emissions caused by deforestation occur in the same year, and biomass loss is counted only above ground:

$$
E=\sum_{t=2010}^{2018} A_{t} \cdot(C-A v A p) * 3.67
$$

where $E$ refers to the total avoided carbon emission (in tonnes of carbon dioxide) associated to the local RD effect in each year of the programme (2010-2018), $A_{t}$ is the RD estimator (in hectares) for each year $t, C$ is the average carbon stock in the Amazon Forest (tC/hectare, equal to 162.2$)^{3.29}, A v A p$ is the average carbon stock in pasture areas in the Amazon Biome (tC/ha), calculated by the Intergovernmental Panel on Climate Change (IPCC) and equivalent to 7.57. Finally, to convert carbon $(C)$ to carbon dioxide $\left(\mathrm{CO}_{2}\right)$, we multiply the final estimate by a factor of 3.67 .

\subsection{Results and discussion}

\subsubsection{Deforestation}

We begin our analysis by assessing the evolution of forest cover along Pará's borders between 2008 and 2018, in different Brazilian states. Considering the year of 2008 as baseline, Figure 3.6 (Appendix) shows higher decrease in forest cover rates for grid cells in Maranhão, Tocantins, Mato Grosso and Pará. This region, located on the southern and eastern margins of the "Legal Amazon"3.30, is also known as the "Arc of Deforestation", where cattle grazing and soybean farming areas are constantly

\footnotetext{
${ }^{3.28}$ Equation 2.3.4.4, p. 41.

${ }^{3.29}$ We calculate the average of the 13 types of vegetation observed in the Amazon Biome, presented on p. 96 of the Third National Inventory (BRASIL, 2015b).

${ }^{3.30}$ The "Legal Amazon" contains all nine states in the Amazon basin.
} 
expanding. Meanwhile, grid cells from Amazonas, Amapá and Roraima have significantly lower deforestation rates.

We then graphically present our data by plotting annual forest cover rates (y-axis) against the running variable - distance to Pará borders (x-axis). Figure 3.7 divides the running variable into quantile-spaced bins up to $10 \mathrm{~km}$ (optimal bandwidths) on each side of the cutoff, and the average forest cover rate within each bin is plotted against its midpoint and fitted into a linear regression model. Positive distances indicate grid cells within Pará, while negative distances show forest cover rate for the neighbouring states. For the years prior to the programme's launch (2008 - 2010), we do not observe any systematic difference in forest cover rate around the cutoff. Grid cells belonging to Pará start to revert the deforestation trends in the first biennium of the programme, presenting positive differences in forest cover rates. For the 2013-2018 period, we verify a sharp increasing discontinuity between treatment and control grid cells along the borders.

Table 3.3 (Appendix) presents our bias-corrected RD estimates for all years. We use clustered standard errors by $25 \mathrm{~km}$ bins for different model specifications: (I) without controls, (II) with geographic controls (slope, land type and distance to streams) and (III) with geographic and structural controls (distance to roads, urban agglomerations and IBAMA offices). For each model, we also show optimal bandwidths (in km), 95 percent confidence intervals and the effective number of observations.

The $\delta$ estimates, which are defined as the difference in average forest cover when crossing Pará's border, are not significant for 2008 - 2010. As these years correspond to the pre-treatment period, we do not expect significant estimates. During the early stages of the PMV, the results indicate that there might have been a reversal of the trends of forest cover across the state border, as we find positive but non-significant estimates compared to the 2008-2010 period. However, up to 2014, as the confidence interval for some of the model specifications includes the zero point, it is not evident that the effect on forest cover might indeed be different from zero.

From 2015 onwards, point estimates are positive and statistically significant at $5 \%$ and $1 \%$ levels, in all specifications, showing that grid cells within Pará have higher average percentage of forest cover. This local difference - which is equivalent to approximately $0.4 \%$ (or 0.4 ha) at the beginning of the programme - increases to $0.8 \%$ (0.8 ha) in 2015 and continues to increase consistently, in particular after 2016, reaching $1.2 \%$ (1.2 ha) in 2018. The use of control variables leads to slightly smaller estimates 
as well as shorter confidence intervals for the RD treatment effect, which increases the precision of statistical inference.

The lag between the programme's lauch and the observed effects on deforestation can be explained by two main factors. First, since the main foundations of the programme design are local pacts and partnerships among different types of stakeholders, the identification and engagement of the associated industry, community leaders and other groups can take time. Delayed responses to Brazilian forest policies were also identified by Burgess et al. (2019) $)^{3.31}$ and Cisneros et al. $(2015)^{3.32}$.

Second, local elections were held out throughout the country in 2012. In these elections, mayors are elected to four-year term ${ }^{3.33}$, being allowed to serve two consecutive terms and then run for office again after a one-term hiatus. Despite the legal enforcement provided by TAC, the overall programme implementation might have been affected by turnover of mayors ${ }^{3.34}$ due to 2012's elections.

As our unit of analysis is a $1 \mathrm{~km}^{2}$ grid cell, by multiplying the significant estimated coefficient for 2015-2018 period and the corresponding grid cell area, we find that the PMV prevented 1.1 ha/year of deforestation, on average. Considering that an area of 2,400 $\mathrm{km}^{2}$ can be legally deforested within the optimal bandwidth ${ }^{3.35}$, PMV's contribution to avoided deforestation might reach $140 \mathrm{~km}^{2} /$ year, or $561 \mathrm{~km}^{2}$ in the 2015-2018 period. Since these results are valid only for a $10 \mathrm{~km}$ bandwith, it should be interpreted as the lower bound of the overall effect of the programme.

By combining this estimate with total forest that can be deforested in Pará $\left(357,131 \mathrm{~km}^{2}\right)$, we find that the PMV could have avoided an accumulated deforestation of $16,267 \mathrm{~km}^{2}$ (or 1,626,733 ha) in the 2015-2018 period, which corresponds to 4,067 $\mathrm{km}^{2} /$ year (or 406,683 ha/year). Given that nearly 39,486 $\mathrm{km}^{2}$ was cleared in the Brazilian Amazon over the same period ${ }^{3.36}$, our estimates suggest that the programme reduced deforestation in the region by $41 \%$.

\footnotetext{
${ }^{3.31}$ Burgess et al. (2019) while estimating the effect of the PPCDAm, which strengthened the legal penalties associated with illegal deforestation and was launched in 2004, show that the discontinuity in deforestation rates disappears in Brazil in 2006, two years after the official launch.

${ }^{3.32}$ When quantifying the impact of MMA's blacklisting on deforestation, the authors find that its effects materialized only slowly, which may be attributed to the gradual rollout of external support measures.

${ }^{3.33}$ Local elections are held in staggered four-year cycles with state and federal elections and take place in October of the election year, with the winner taking office in January of the following year.

${ }^{3.34} 34 \%$ of PMV's municipalities which signed a TAC before 2012 experienced change in mayors in the 2012 elections.

${ }^{3.35}$ Excluding indigenous lands, conservation units and urban areas.

${ }^{3.36}$ Based on PRODES data.
} 
Table 3.4 (Appendix) presents the RD effect excluding 7 out of the 13 municipalities from Pará and 5 out of 9 municipalities from other states (See Figure 3.4), which were part of the 2007 MMA's priority list. In theory, these municipalities could have received more benefits from reducing deforestation, as they were suffering from economic sanctions and political pressures. Controlling for geographic and structural variables, our bias-corrected estimates show that forest cover differences become positive and significant between state borders after 2013. This suggests that the effects of the programme came mainly from the municipalities that already had deforestation rates below the PMV's target - that is, $40 \mathrm{~km}^{2}$ per municipality. Therefore, it seems that these participants were able to sustain their deforestation levels and might have been able to earn the additional indirect benefits that the PVM offers. However, the PMV's incentives might not be sufficient for municipalities with urgent needs to reduce deforestation pressures.

As the PMV's working agenda focuses on supporting environmental regularisation through CAR registration, our findings suggest that in settings where deforestation pressures are high, there is a need to question: (i) how the CAR may affect deforestation behaviour and (ii) to what extent the given information is complete and accurate since it is self-declared system. In the Amazon context, there is evidence that non- registration has little impact on deforestation behaviour except for small properties in the size range of 100-300 ha. Motivations for registration and reducing deforestation are more tied to incentives from a parallel land policy (land titling process) as opposed to the incentives offered directly by the CAR (Rasmussen et al., 2017; L'Roe et al., 2016). In addition, currently, over $120 \%$ of Pará is registered under the CAR system, indicating areas registered more than once ruralsicar.

Our general findings are aligned with the previous study about the PMV, and the international evidence about the effectiveness of decentralization measures to prevent forest clearing in developing countries. Particularly for the PMV, Santos et al. (2016) find no evidence that PMV municipalities were reducing their levels of deforestation. When considering only participant municipalities with better environmental indicators, classified as "consolidated" and "monitored and under control", the evidence suggests they managed to maintain their deforestation levels. The differences observed in the timing of the deforestation effects might have been caused by the difference in data granularity, as the authors use municipal-level data and do not take into account spatial effects. Andersson and Gibson (2007), Baland et al. (2010) and Miteva et al. (2012) suggest that decentralized schemes to support forest conservation might present 
significant effects mainly in the long run, which also might be heterogeneous across different regions.

\subsubsection{Avoided $\mathrm{CO}_{2}$ emissions}

Figure 3.8 (Appendix) shows our result of avoided $\mathrm{CO}_{2}$ emissions due to the reduction on forest clearing, per year. These carbon estimates are conservative since we did not include below ground biomass values. Since the point estimates are not different than zero up to 2015, we calculate that the programme might have avoided emissions of approximately $8.0 \mathrm{MtCO}_{2} /$ year between 2015 and 2018. As Brazilian emissions from land use change were, on average, $866 \mathrm{MtCO}_{2} /$ year in the same period (SEEG, 2019), our results indicate that the PMV might have avoided $0.9 \%$ of land use-related emissions.

Considering an average price of US $\$ 5 / \mathrm{tCO}_{2}$ commonly used in current applications, the PMV would be able to store $\mathrm{CO}_{2}$ valued at US\$ 40 million/year. Our figures also represent approximately $7.4 \%$ of the annual avoided deforestation from the PPCDAm estimated by Assunção et al. (2015), which amounts to 2.7 billion tonnes of $\mathrm{CO}_{2}$ for the 2004-2008 period. Taking the average social cost of carbon of US\$ $80 / \mathrm{tCO}_{2}$ as suggested by Pindyck (2019), we estimate that the PMV's preserved forest area is valued at more than US\$ 636 million/year.

\subsection{Robustness tests}

In this section, we evaluate the robustness of our findings vis-à-vis alternative bandwidth sizes. We also run tests accounting for unobservable heterogeneity at the year and municipal levels and excluding areas potentially affected by confounding factors. A placebo test is also conducted to increase confidence in our estimated RD treatment effects.

\subsubsection{Sensitivity to bandwidth choice}

As the estimation of the RDD treatment effect is sensitive to the bandwidth selection, we also investigate the potential results employing local polynomial methods with different non-optimal bandwidth choices. Figure 3.9 (Appendix) plots the RD 
point estimates and the associated $95 \%$ confidence intervals, as a function of optimal, 20 $\mathrm{km}$ and $30 \mathrm{~km}$ bandwidths. Coefficients are consistently positive and significant for the 2013-2018 period, suggesting they are not critically dependent on a particular bandwidth choice. The effects on years prior to the programme are statistically insignificant in all cases.

\subsubsection{Sensitivity to other programmes - Bolsa Verde}

Payments for ecosystem services and income support schemes have been widely used to compensate poor households in rural and forest communities for environmental conservation. One of these programmes is Bolsa Verde, a federal programme managed by the MMA and also launched in 2011. It focuses on poor rural people residing in sustainable use protected areas and rural settlements in all Brazilian regions. To be eligible for benefits, families must be already participating in Bolsa Família ${ }^{3.37}$ and meet environmental requirements (to live in an area that meets the requirements established by the Brazilian Forest Code in relation to native vegetation remnants, which must also possess a management plan or similar documents). The benefit corresponds to $\mathrm{R} \$ 300$ per quarter.

Between 2011 and 2013, 78.339 households located in 343 rural settlements in Pará received $62.9 \%$ of total programme expenditures (approximately $\mathrm{R} \$ 43.5$ million), followed by 24.230 households from 71 rural settlements in Amazonas ( $\mathrm{R} \$ 6.3$ million or $9.1 \%$ ) (Viana, 2014). Given the importance of this region to the programme, we test the sensitivity of our regression results by excluding from our dataset all grid cells located in rural settlements, as the incentives to curb deforestation might be higher in these areas.

Table 3.5 (Appendix) presents the RD estimates after removing $19 \%$ of our grid cells located in 544 rural settlements (234 and 310 within and outside Pará, respectively) - which corresponds to an area of $63,581 \mathrm{~km}^{2}$ and 332,017 observations, of which $51 \%$ (or $32,523 \mathrm{~km}^{2}$ ) belong to Pará. Overall, we do not find substantial differences compared to our preferred specification. However, point estimates are positive $(0.7 \%)$ and significant

\footnotetext{
3.37 Bolsa Família is a conditional cash transfer programme introduced in Brazil in 2003, in which families received financial support on the condition of sending their children to school and ensuring proper vaccination. Low-income families (with per capita monthly income up to $\mathrm{R} \$ 70$ ) are entitled to a fixed household transfer of $\mathrm{R} \$ 70$ plus an additional amount of $\mathrm{R} \$ 32$ for each child up to 15 years of age, to a maximum of five, and an additional amount of $\mathrm{R} \$ 38$ for each youth aged 16-17, to a maximum of two. The maximum benefit amount for households in extreme poverty is $\mathrm{R} \$ 242$.
} 
one year after the programmes' launch (2012), suggesting that forest cover rates in these areas might be lower than in areas eligible for legal deforestation.

\subsubsection{Placebo test: full protection conservation units}

The National System of Conservation Units (SNUC) groups conservation units into two main groups, according to their management objectives and use: (i) Full Protection and (ii) Sustainable Use. The main objective of Full Protection Units is to preserve nature, with allowance only of indirect use of natural resources, that is, use that does not involve consumption, collection or damage to natural resources - such as ecological tourism. Sustainable Use Units, in turn, aim to make nature conservation compatible with the sustainable use of resources, reconciling human presence in protected areas. In this group, activities that involve the collection and use of natural resources are allowed, as long as they are practiced in a way that keeps renewable environmental resources and ecological processes constant.

In our $100 \mathrm{~km}$ buffer zone, we identify 11 full protection units which comprises national parks (PARNA), biological reserves (REBIO) and biological stations (ESEC), as presented in Table 3.6 (Appendix). Except for the Alto Maués Ecological Station and Acari National Park, they were all created before 2008. We use forest cover data of grid cells located in these eleven units to conduct our placebo test, using all geographic and structural controls. Robust and bias-corrected estimates are presented in Table 3.7 (Appendix), suggesting there are no significant differences in forest cover and deforestation rates in these areas.

\subsubsection{Accounting for unobservable heterogeneity}

To account for observable heterogeneity in the rollout of the PMV across space and time, we calculate the average treatment effect in individual years using differencein-differences (DID) estimator with leads and lags. Since municipalities adhered to PMV in different years, this approach enables us to verify how the PMV's effects on forest cover evolved over time, making a direct comparison with our results obtained from Equation 3.2.

The fundamental assumption of DID estimation that leads to unbiased estimates is that grid cells belonging to Pará municipalities would have the same deforestation trend as the grid cells in other neighbouring states, once relative tendency deviations 
between these grid cells are assigned to the PMV. Based on the year each municipality signed the TAC with the MPF or the agreement with the PMV coordination, we create dummy variables for 10 years before and 8 years after the PMV adherence. If the effects on forest cover are not driven by confounding trends in unobservable factors, we should not expect ex ante significant differences in trends; likewise, if our results obtained from Equation 3.2 are not biased, we should only observe delayed changes in tendencies after the PMV's launch. Formally, we estimate the following equation:

$$
Y_{i t}=\alpha_{i}+\alpha_{m}+\sum_{k=t-10}^{k=t+8} \delta_{k} 1 \text { Pará }+\gamma X_{i t}+\varepsilon_{i t}
$$

where $\alpha_{m}$ and $\alpha_{t}$ are municipality and year fixed effects that control for differences in time-invariant unobservables across areas and year-specific unobservables affecting deforestation in all grid cells. 1 is the product of the time and treatment dummy indicator for years $t-10$ and $t+8$. We use $25 \mathrm{~km}$ clustered standard errors to control for arbitrary spatial and serial correlation.

Table 3.8 presents the point estimates for forest cover rate relative to the PMV' launch year and the respective 95\% confidence interval for two specifications: (1) excluding grid cells from rural settlements as they might be eligible for Bolsa Verde and (2) excluding additional grid cells belonging to priority municipalities. $\delta$ estimates should be interpreted as the differences in forest cover rate with reference to year $t=0$.

We find no statistically significant difference in forest cover patterns before and after the PMV launch, suggesting that the deforestation pattern follows parallel trends within and outside Pará. Despite being not significant, point estimates become positive for grid cells located within Pará after the first year of the programme. $\delta$ estimates are positive and significant after PMV's third year, and these differences remain until the final year analysed, when it reaches more than $1 \%$. Comparing the results obtained from Equation 3.2 (Table 3.4, Appendix), cumulative avoided deforestation between 2015 and 2018 amounts to $9,689 \mathrm{~km}^{2}$ and 12,476 $\mathrm{km}^{2}$ for specifications (1) and (2), respectively, an area approximately the size of Cyprus. 


\subsection{Conclusions and policy implications}

The PMV, a decentralized and voluntary programme implemented in Pará state, aimed to mitigate one of the highest deforestation rates in the Amazon Biome $(2,700$ $\mathrm{km}^{2}$ /year) by empowering municipalities to improve their natural resource management through multi-sector partnerships. This paper aims to assess the PMV's effectiveness in reducing deforestation levels, and we address the selection bias problem by using a high-resolution panel dataset and a nonparametric spatial RD, which allow us to compare forest cover rates within and outside the state.

Our main finding is that the effect on forest cover is positive but observed at the later stages of the programme, as differences in forest cover rates between grid cells from Pará and non-Pará municipalies become consistently significant only after 2015. On average, PMV might have prevented 1.1 ha/year of deforestation, which is equivalent to $140 \mathrm{~km}^{2} /$ year and $8.0 \mathrm{MtCO}_{2} /$ year of avoided deforestation and emissions, respectively, within the 10-km optimal bandwidth. Considering the total area that could be legally deforested in Pará, the extrapolation of our estimates indicates that the PMV might have prevented $41 \%$ of deforestation in the Amazon region. However, since these effects come mainly from areas with traditionally low deforestation pressures, the advantages provided by the programme - such as higher legal security, better access to credit and tax incentives- seem to be insufficient for areas more vulnerable to illegal forest clearance.

These results have practical implications for environmental policy. In its NDC, Brazil has committed to eliminate deforestation in the Amazon by 2030, which currently amounts to $7,200 \mathrm{~km}^{2} /$ year. Decentralized programmes with focus on indirect benefits appear to be effective mainly in the long run, serving as a "bonus" to support those regions with higher levels of forest cover. However, future policies with similar design should consider different strategies and plans according to types of deforestation. In this sense, further studies could better assess the mechanisms behind the PMV and the effectiveness of other decentralized and voluntary policies against illegal deforestation. 



\section{APPENDIX}

\section{A Tables and Figures}

Figure 3.1 - Location of the study area: Pará's borders

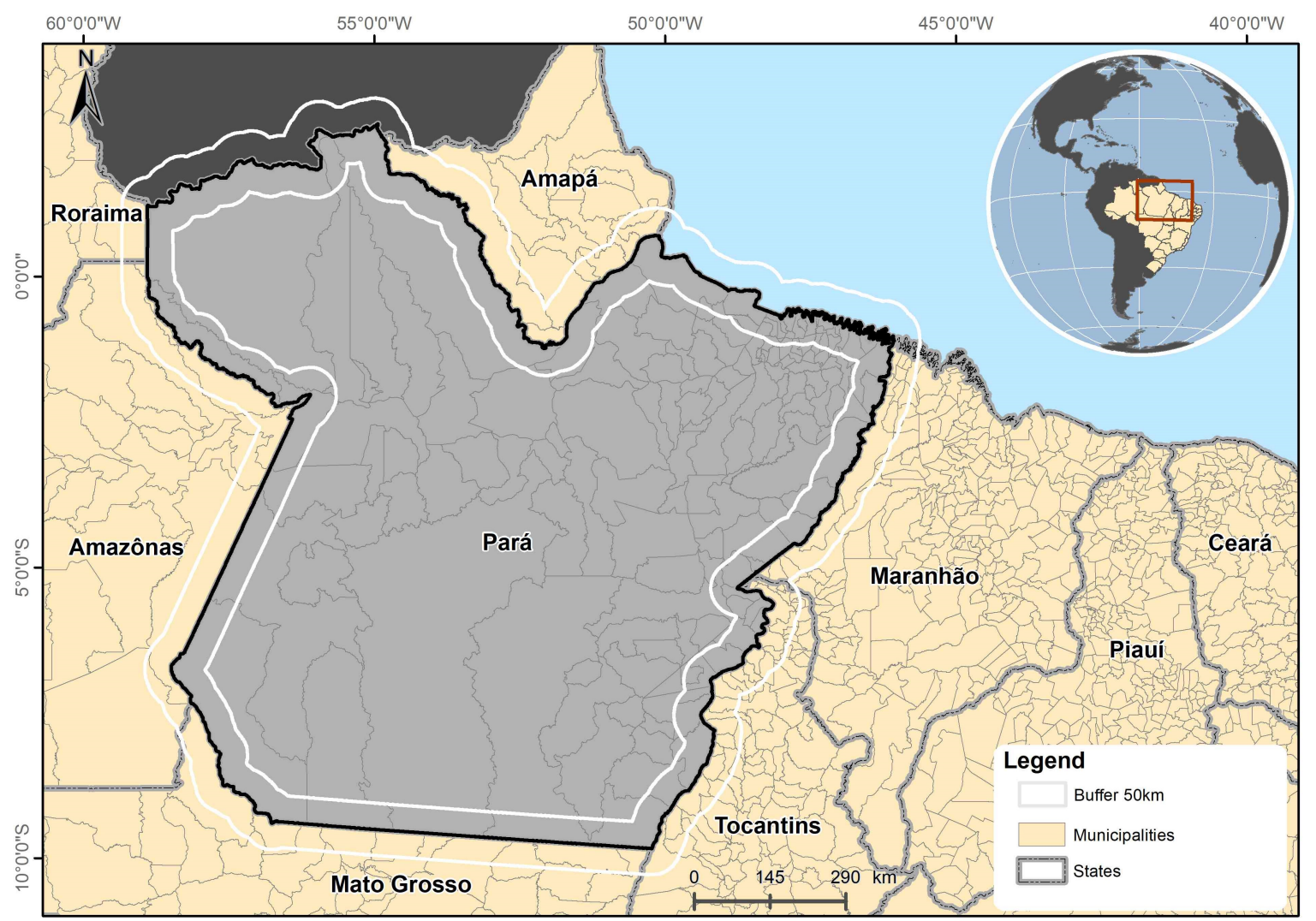

Note: This figure identifies the $50 \mathrm{~km}$ buffer zone (white line) constructed from our cutoff, Pará's borders (black line). This area is equivalent to $457,854 \mathrm{~km}^{2}$. Gray shaded areas correspond to Pará's borders with Guyana and Suriname. 
Table 3.1 - List of Pará municipalities that are part of the PMV

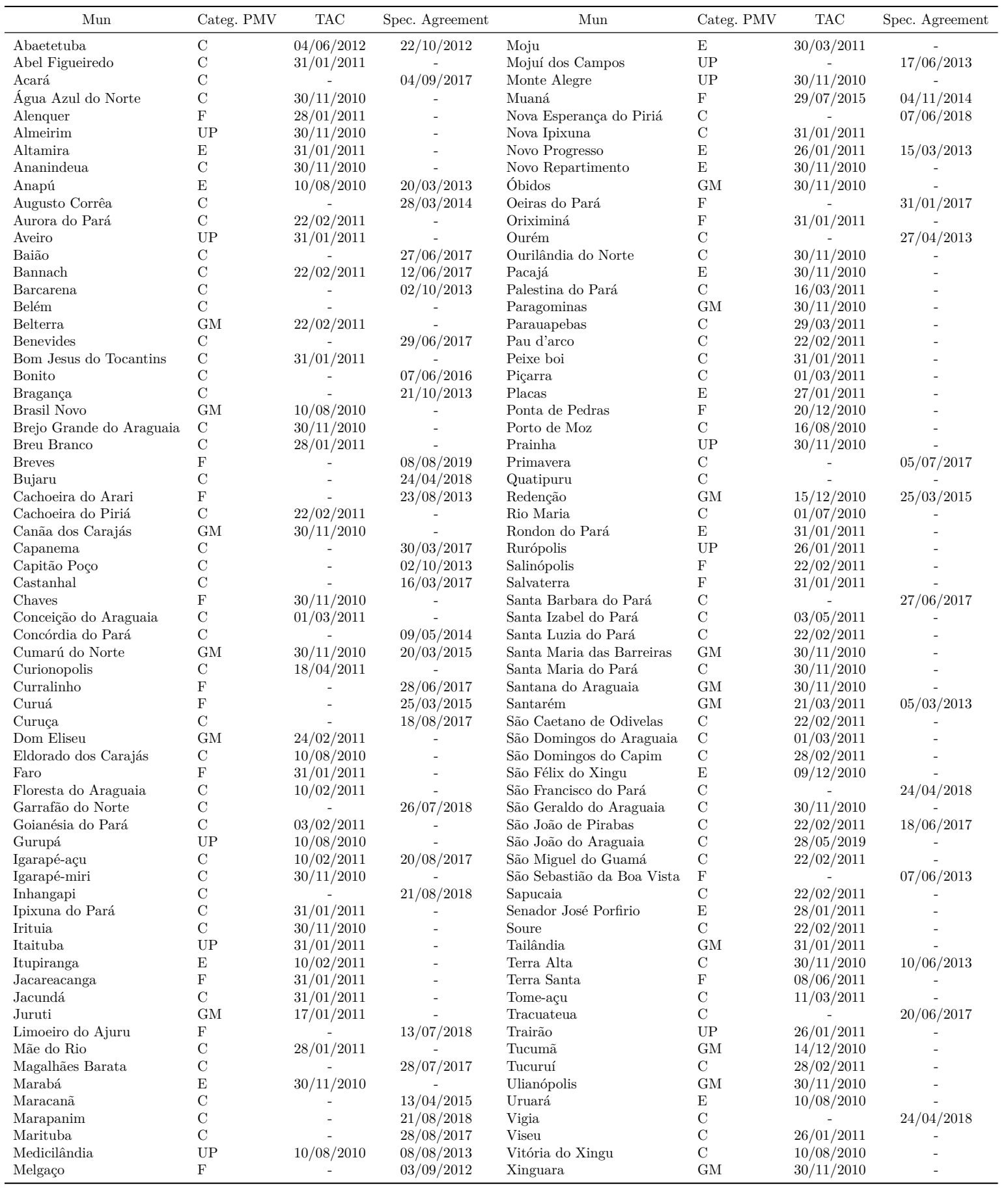

Note: This table lists the municipalities that are part of the PMV, their Note: $\mathrm{E}=$ Embargoed (MMA priority list), $\mathrm{UP}=$ Under Pressure, $\mathrm{C}=$ Consolidated, $\mathrm{F}=$ Forest Base; $\mathrm{GM}=$ Green Municipality. 
Figure 3.2 - Annual deforestation in the Brazilian Amazon

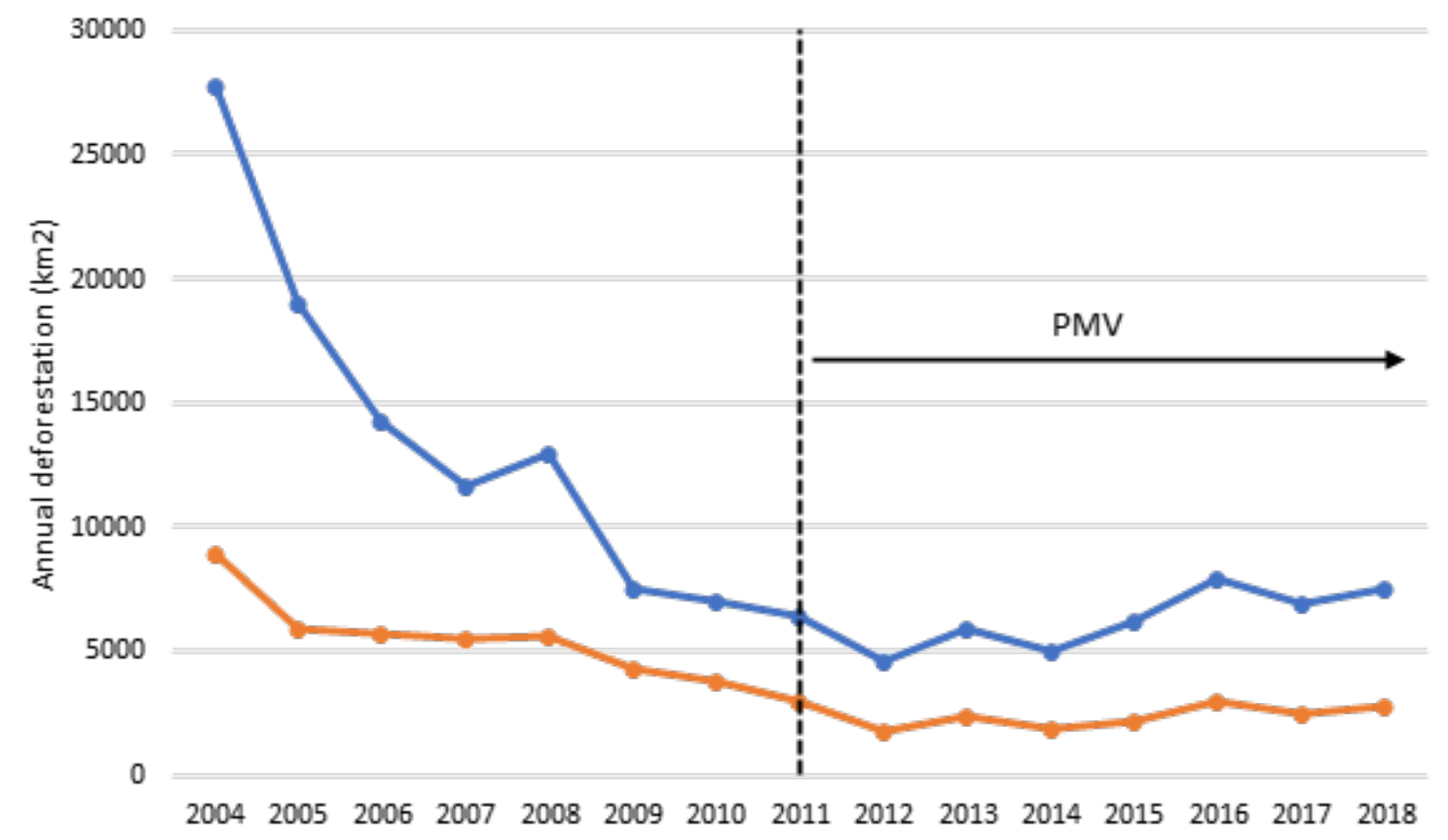

Note: This figure shows the total annual deforestation in the Brazilian Amazon (in blue), and annual deforestation in Pará (in red), in $\mathrm{km}^{2}$, based on data from PRODES. The dotted black line indicates the PMV's launch. 
Figure 3.3 - Location of study area: grid cells within $100 \mathrm{~km}$ buffer zone

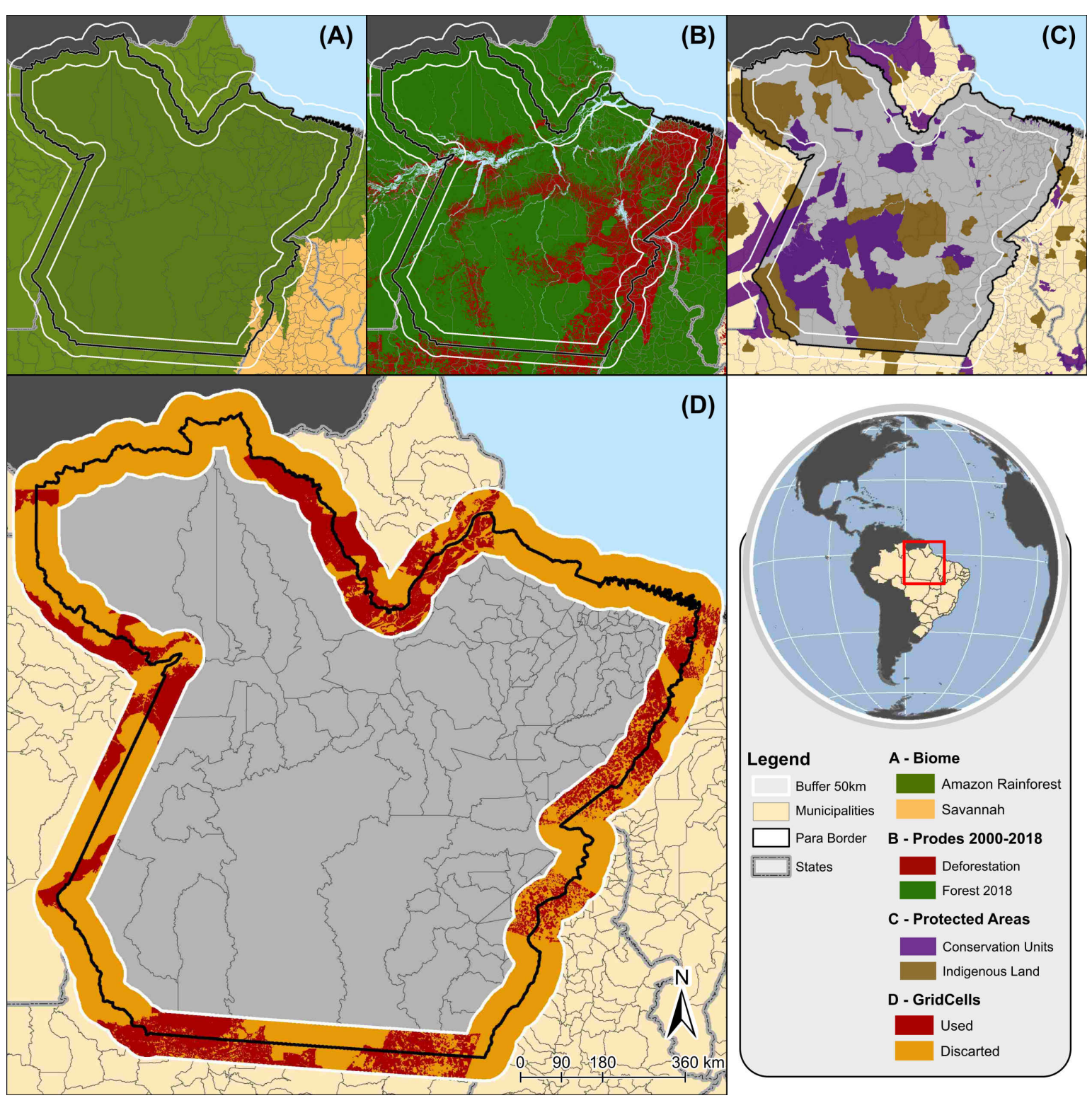

Note: This figure shows the process to obtain the final grid cells (D). Figure (A) maps the Amazon biome, and Figure (B) shows the forest area (in green) and the deforested area (in red). Figure (C) shows the location of state and federal indigenous lands and conservation areas in Pará and the surrounding states, identified based on data from IBGE. Figure (D) shows the grid cells that were used (in red) and discarded (in yellow) within the $50 \mathrm{~km}$ buffer zone (white line) from Pará's borders (cutoff). Discarded grid cells corresponds to areas closer to the Cerrado biome, Atlantic Ocean, international borders or that belong to indigenous lands and conservation areas, identified based on data from PRODES and IBGE - which are equivalent to $103,731 \mathrm{~km}^{2}$. Total grid cell area in red is equivalent to $162,242 \mathrm{~km}^{2}$. 
Figure 3.4 - PMV: municipalities according to year of adherence

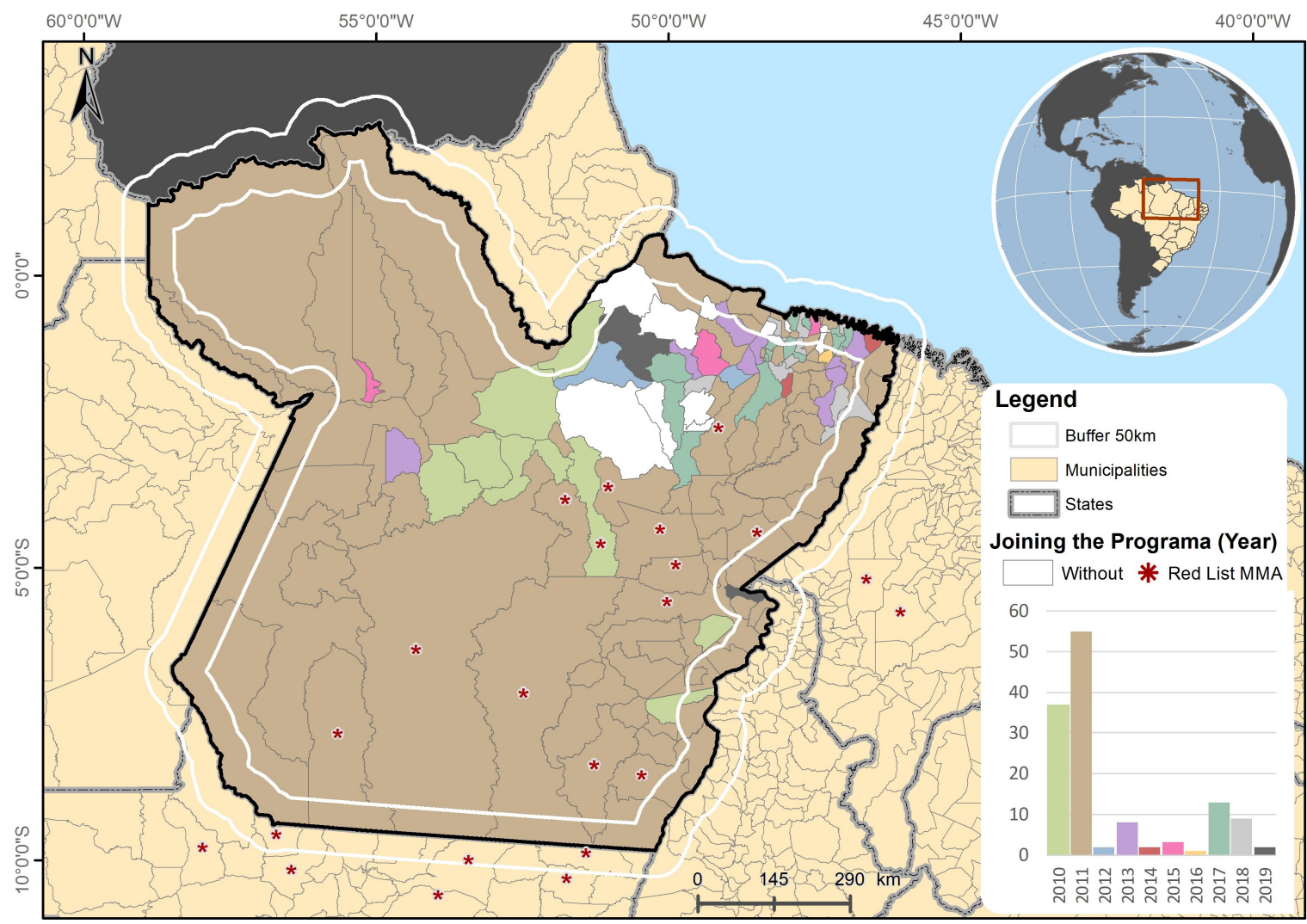

Note: This figure presents the location and number (graph below) of municipalities according to the year of adherence to the programme, and the red asterisk indicates the municipalities from 2007 MMA's list. 
Figure 3.5 - Maps of control variables

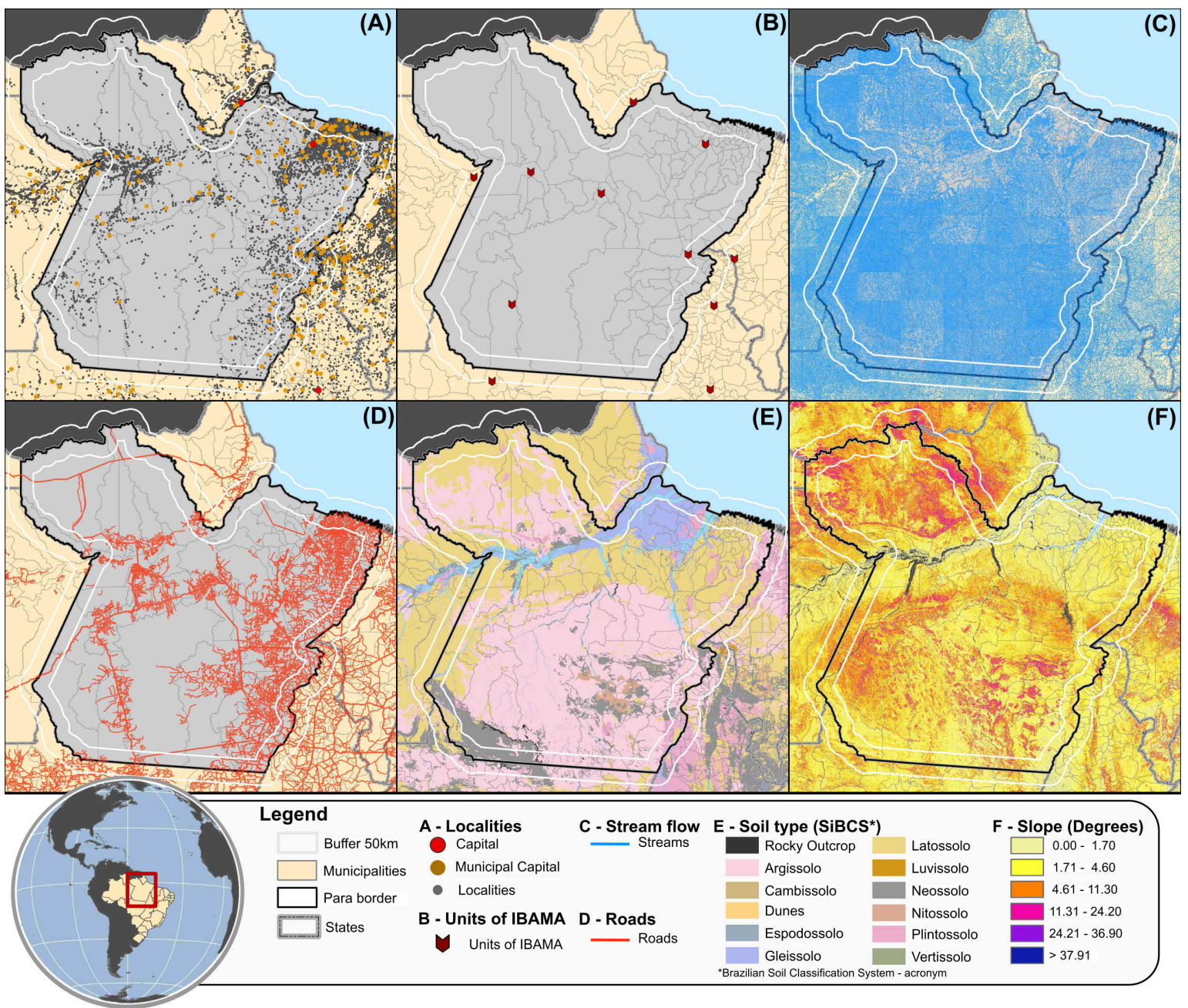

Note: These maps shows the details of our geographic ((C) streams; (E) soil type and (F) slope) and structural covariates ((A) municipalities (incl. villages); (B) IBAMA offices; (D) official and unofficial roads). 


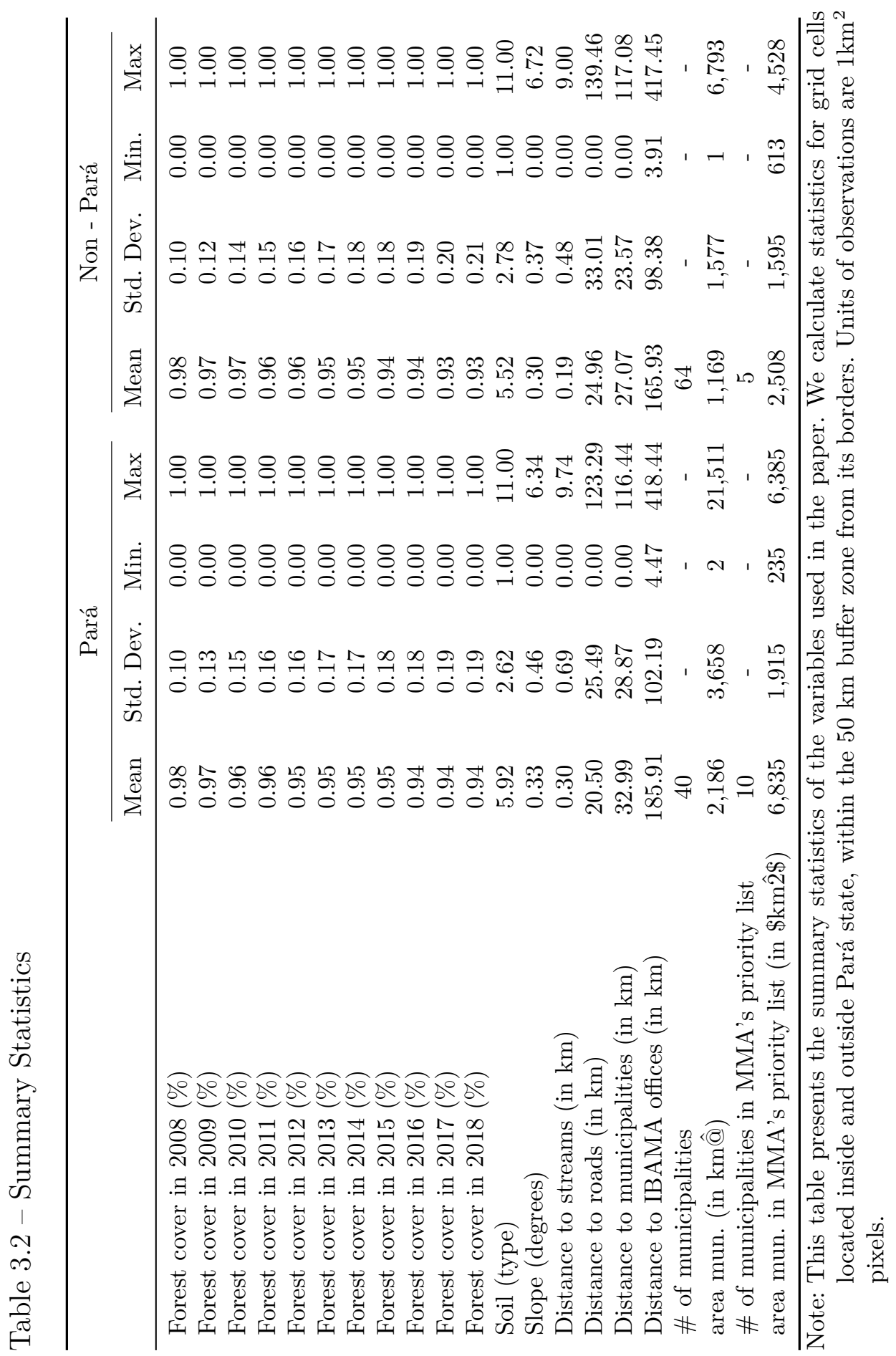


Figure 3.6 - Average annual forest cover at Pará Borders in different Brazilian states (excluding conservation units and indigenous lands)

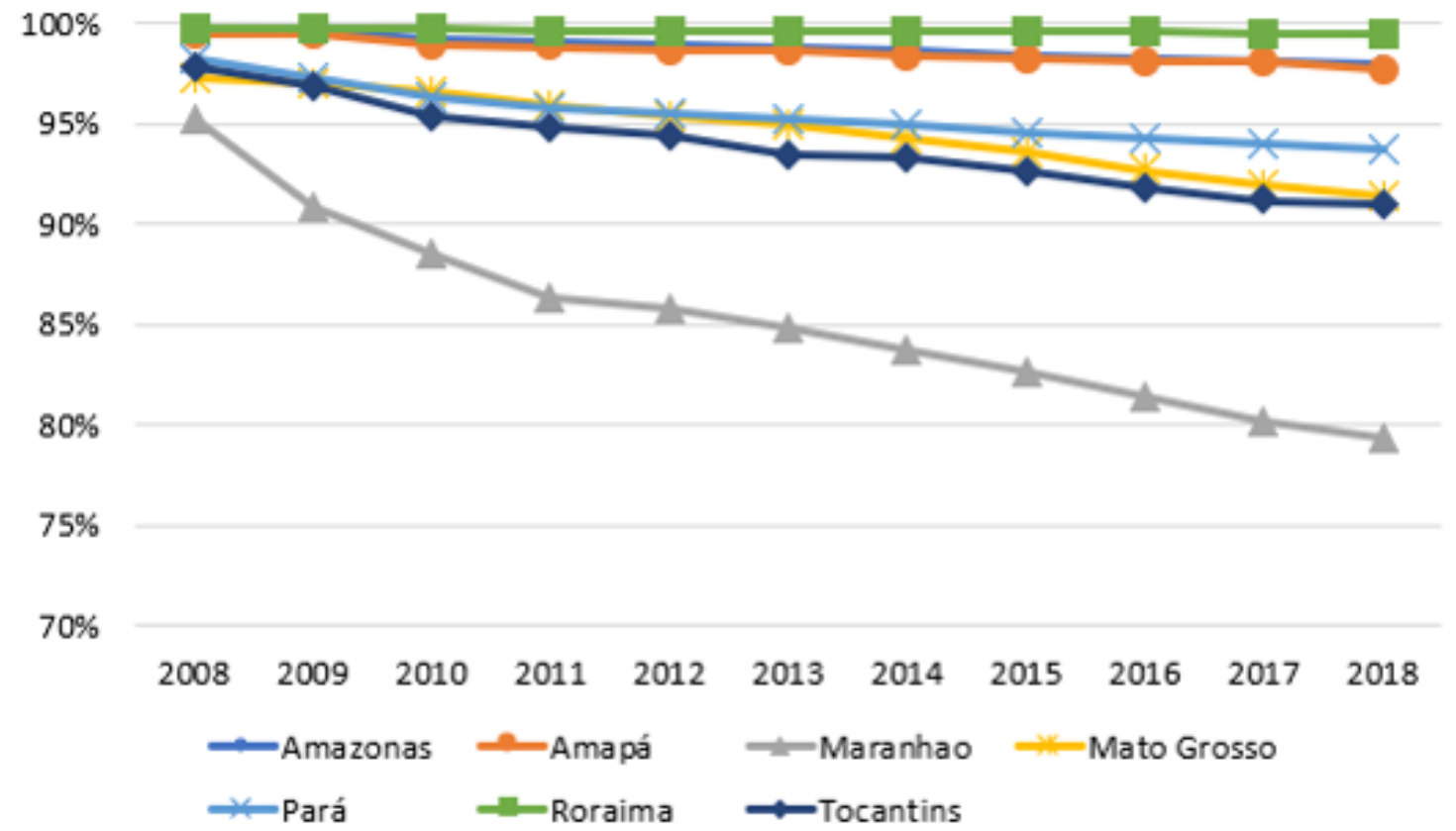

Note: This figure presents the average annual forest cover between 2008 and 2010 in different states along Pará's borders, based on PRODES data. Evolution of forest cover is calculated considering 2008 as the base year. 
135

Figure 3.7 - RD Effects - \% of forest cover
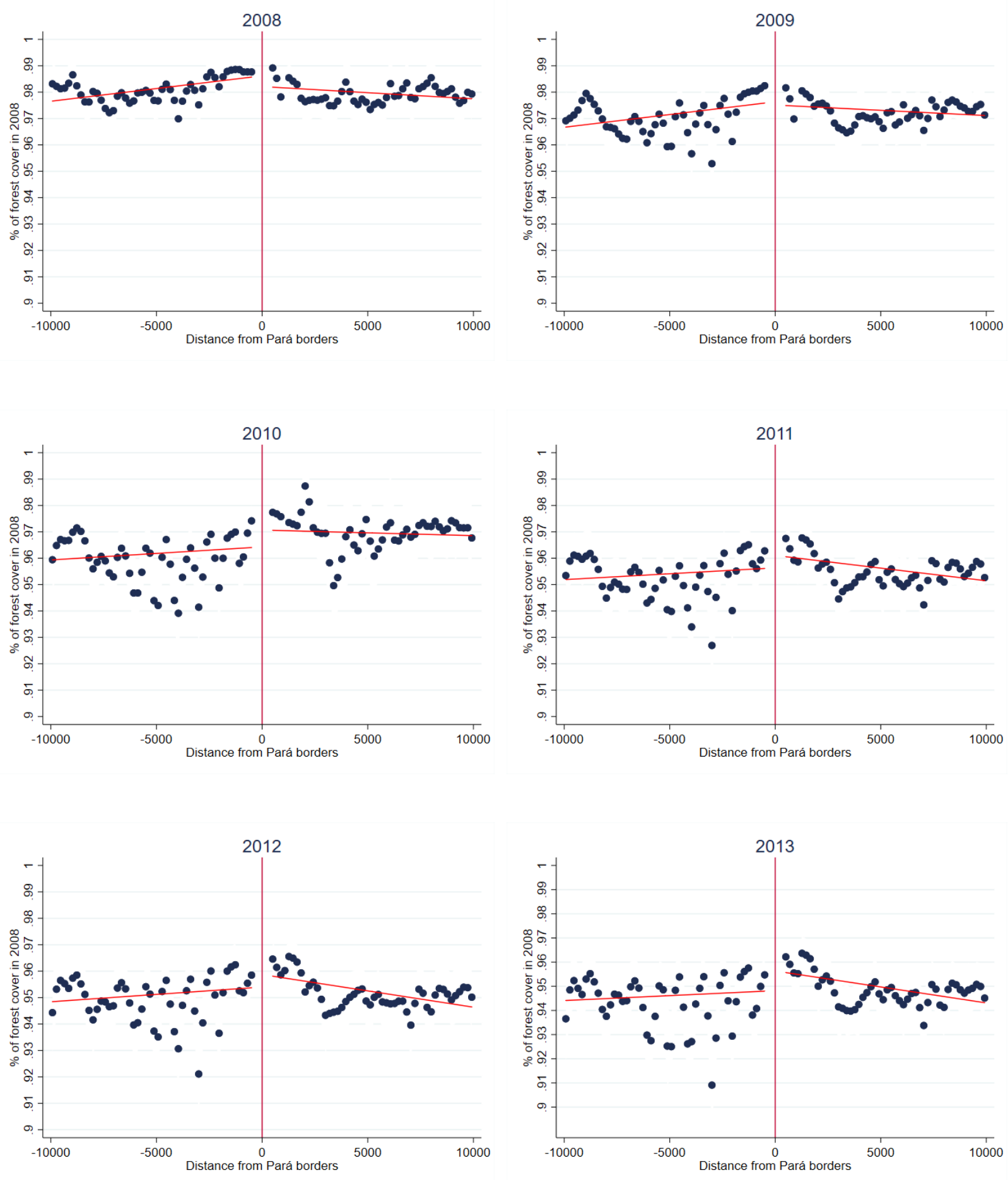

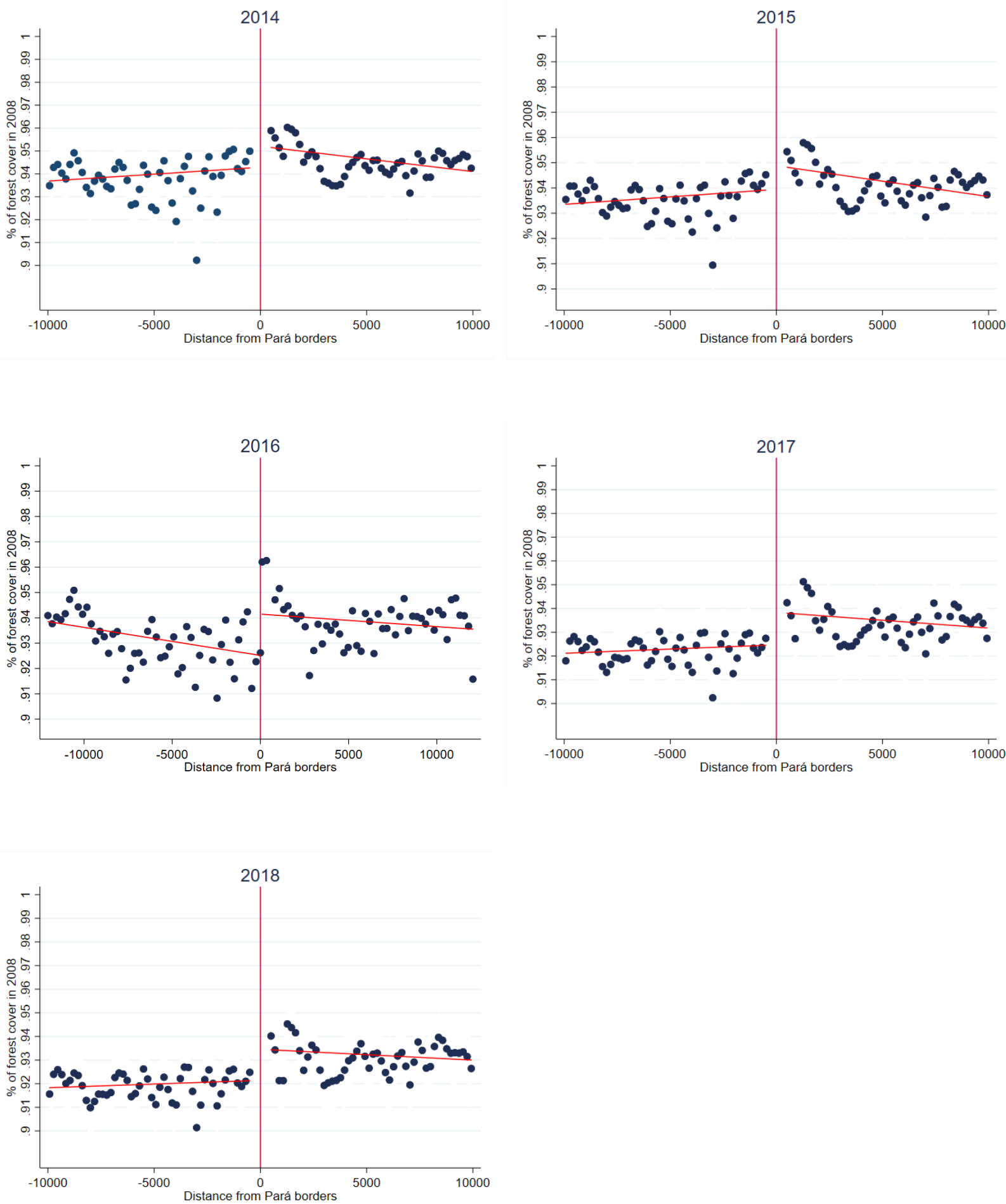

Note: This figure shows the average annual forest cover between 2008 and 2018 by quantile-sized bins of distances from the Pará border, within the optimal bandwidth (up to 1000 meters away from Pará's border). Positive distance represents forest cover within Pará, while negative distance represents other states. The red lines show the linear function of distance weighted by the number of observations in each bin. 
Table 3.3 - RD estimator effect on $\%$ of forest cover $(\delta)$

\begin{tabular}{|c|c|c|c|c|c|c|c|}
\hline Year & Controls & Opt. Band & $\delta$ & $\mathrm{Sd}$ & \multicolumn{2}{|c|}{$\mathrm{CI}$} & \# obs. \\
\hline \multirow{3}{*}{2008} & I & 8.9 & -0.396 & 0.235 & -0.954 & 0.131 & 1418916849 \\
\hline & II & 9.1 & -0.374 & 0.232 & -0.942 & 0.133 & 1418916849 \\
\hline & III & 9.0 & -0.374 & 0.232 & -0.923 & 0.154 & 1418916849 \\
\hline \multirow{3}{*}{2009} & I & 7.4 & -0.165 & 0.289 & -0.912 & 0.357 & 1164213743 \\
\hline & II & 11.1 & -0.155 & 0.245 & -0.800 & 0.313 & 1717920687 \\
\hline & III & 11.3 & -0.181 & 0.242 & -0.775 & 0.336 & 1729220845 \\
\hline \multirow{3}{*}{2010} & I & 8.7 & 0.480 & 0.371 & -0.452 & 1.233 & 138438369 \\
\hline & II & 10.1 & 0.523 & 0.348 & -0.372 & 1.232 & 156749614 \\
\hline & III & 10.0 & -0.006 & 0.349 & -0.838 & 0.768 & 156749614 \\
\hline \multirow{3}{*}{2011} & 1 & 10.2 & 0.410 & 0.346 & -0.434 & 1.161 & 1596818377 \\
\hline & II & 12.0 & 0.400 & 0.310 & -0.347 & 1.116 & 1869221730 \\
\hline & III & 10.6 & 0.273 & 0.335 & -0.460 & 1.073 & 1661719110 \\
\hline \multirow{3}{*}{2012} & I & 10.4 & 0.532 & 0.354 & -0.281 & 1.360 & 1596818377 \\
\hline & II & 11.4 & 0.466 & 0.337 & -0.300 & 1.240 & 1744720228 \\
\hline & III & 9.9 & 0.406 & 0.355 & -0.342 & 1.271 & 1567417990 \\
\hline \multirow{3}{*}{2013} & I & 10.8 & $0.864^{* *}$ & 0.366 & 0.023 & 1.719 & 1701019641 \\
\hline & II & 12.2 & $0.813^{* *}$ & 0.344 & 0.021 & 1.596 & 1877721854 \\
\hline & III & 10.3 & $0.722^{*}$ & 0.368 & -0.059 & 1.618 & 1596718377 \\
\hline \multirow{3}{*}{2014} & I & 10.3 & $981^{* *}$ & 0.393 & 0.032 & 1.850 & 1596 \\
\hline & II & 12.7 & $0.950^{* *}$ & 0.350 & 0.087 & 1.720 & 1951722712 \\
\hline & III & 10.5 & $0.830^{*}$ & 0.382 & -0.010 & 1.730 & 1661719110 \\
\hline \multirow{3}{*}{2015} & I & 10.5 & $1.017^{* *}$ & 0.403 & 0.091 & 1.962 & 1661819110 \\
\hline & II & 12.5 & $0.959^{* *}$ & 0.369 & 0.076 & 1.772 & 1942722601 \\
\hline & III & 10.0 & $0.860^{* *}$ & 0.404 & 0.018 & 1.844 & 1567417990 \\
\hline \multirow{3}{*}{2016} & I & 12.2 & $1.312^{* *}$ & 0.414 & 0.396 & 2.320 & 1877821854 \\
\hline & II & 14.2 & $1.276^{* * *}$ & 0.380 & 0.433 & 2.164 & 2150525282 \\
\hline & III & 11.1 & $1.136^{* *}$ & 0.424 & 0.285 & 2.186 & 1717919861 \\
\hline \multirow{3}{*}{2017} & I & 11.7 & $1.518^{* * *}$ & 0.430 & 0.490 & 2.518 & 1822521108 \\
\hline & II & 11.5 & $1.513^{* * *}$ & 0.379 & 0.686 & 2.403 & 2294427155 \\
\hline & III & 11.5 & $1.316^{* * *}$ & 0.428 & 0.466 & 2.364 & 1813020993 \\
\hline \multirow{3}{*}{2018} & I & 12.6 & $1.475^{* * *}$ & 0.429 & 0.459 & 2.456 & 1942822601 \\
\hline & II & 13.6 & $1.428^{* * *}$ & 0.408 & 0.414 & 2.307 & 2087324423 \\
\hline & III & 11.0 & $1.243^{* * *}$ & 0.445 & 0.243 & 2.290 & 1717919861 \\
\hline
\end{tabular}

Note: This table presents the regression estimates of the Pará dummy, $\delta$ (in \%), on forest cover between 2008 and 2018, calculated using linear polynomials. We provide three different specifications (column 'Controls'): (I) without controls; (II) with geographic controls and (III) with geographic and structural controls. Column 'Opt.Band' refers to the average optimal and bias-correction bandwidth (Cattaneo et al., 2019) of our dependent variable in kilometres, 'Sd' and 'CI' indicate the respective standard errors, clustered using $25 \mathrm{~km}$ bins, and the 95 percent confidence intervals. Number of clusters varies according to year and model specification. Units of observations are $1 \mathrm{~km}^{2}$ pixel within the $50 \mathrm{~km}$ from Pará's border. Significance levels: ${ }^{*} 10 \%,{ }^{*} 5 \%, * * * 1 \%$. 
Table 3.4 - RD estimator effect on \% of forest cover $(\delta)$ excluding MMA's priority list municipalities

\begin{tabular}{|c|c|c|c|c|c|c|}
\hline \multirow[b]{2}{*}{ Year } & \multirow[b]{2}{*}{ Opt. Band } & \multirow[b]{2}{*}{$\delta$} & \multicolumn{2}{|c|}{ Robust Inference } & & \multirow{2}{*}{ \# of obs. } \\
\hline & & & $\mathrm{Sd}$ & $\mathrm{CI}$ & & \\
\hline 2008 & 9.2 & -0.287 & 0.240 & -0.867 & 0.238 & 1418913093 \\
\hline 2009 & 8.4 & -0.178 & 0.280 & -0.911 & 0.354 & 1303312003 \\
\hline 2010 & 7.8 & 0.854 & 0.395 & -0.168 & 1.594 & 124245962 \\
\hline 2011 & 10.4 & 0.605 & 0.350 & -0.193 & 1.427 & 1596814895 \\
\hline 2012 & 10.5 & 0.686 & 0.358 & -0.098 & 1.553 & 1661815466 \\
\hline 2013 & 10.7 & $1.006^{* *}$ & 0.376 & 0.188 & 1.918 & 1680815675 \\
\hline 2014 & 10.5 & $1.178^{* *}$ & 0.397 & 0.286 & 2.121 & 1596814895 \\
\hline 2015 & 10.0 & $1.226^{* * *}$ & 0.421 & 0.337 & 2.273 & 1567514557 \\
\hline 2016 & 11.7 & $1.347^{* * *}$ & 0.436 & 0.412 & 2.429 & 1822517113 \\
\hline 2017 & 11.7 & $1.480^{* * *}$ & 0.450 & 0.442 & 2.540 & 1822517113 \\
\hline 2018 & 12.4 & $1.386^{* *}$ & 0.448 & 0.332 & 2.418 & 1906618070 \\
\hline
\end{tabular}

Note: This table shows the regression estimates of the Pará dummy, $\delta$ (in \% or hectares), on forest cover between 2008 and 2018, excluding the 13 municipalities on the 2007 MMA's list and using linear polynomials. Column 'Opt.Band' refers to the average optimal and bias-correction bandwidth (Cattaneo et al., 2019) of our dependent variable in kilometres, 'Sd' and 'CI' indicate the respective standard errors, clustered using $25 \mathrm{~km}$ bins, and the 95 percent confidence intervals. Number of clusters varies according to year. Units of observations are $1 \mathrm{~km}^{2}$ pixel within the $50 \mathrm{~km}$ from Pará's border, and number of observations are separated by left and right side of the state borders within the optimal bandwidth. Significance levels: ${ }^{*} 10 \%,{ }^{*} 5 \%,{ }^{* * *} 1 \%$. 
Figure 3.8 - Avoided $\mathrm{CO}_{2}$ emissions $\left(\mathrm{MtCO}_{2}\right)$

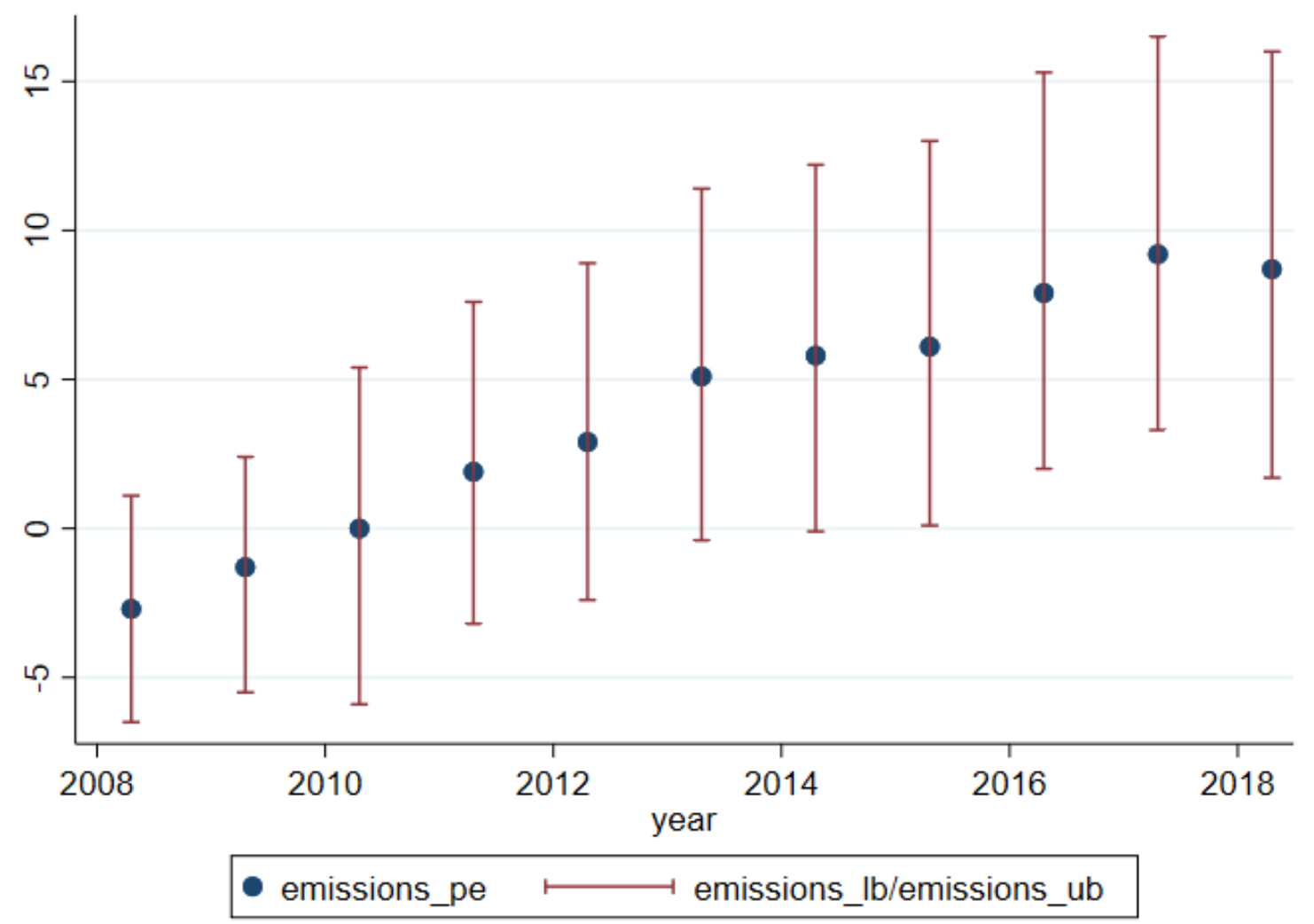

Note: This figure presents our point estimates and the corresponding $95 \%$ confidence interval for avoided $\mathrm{CO}_{2}$ released to the atmosphere due tothe PMV. Values are estimates based on aboveground biomass and the respective coefficients from BRASIL (2015b). 
Figure 3.9 - Sensitivity to bandwidth choice (optimal, $20 \mathrm{~km}$ and $30 \mathrm{~km}$ )

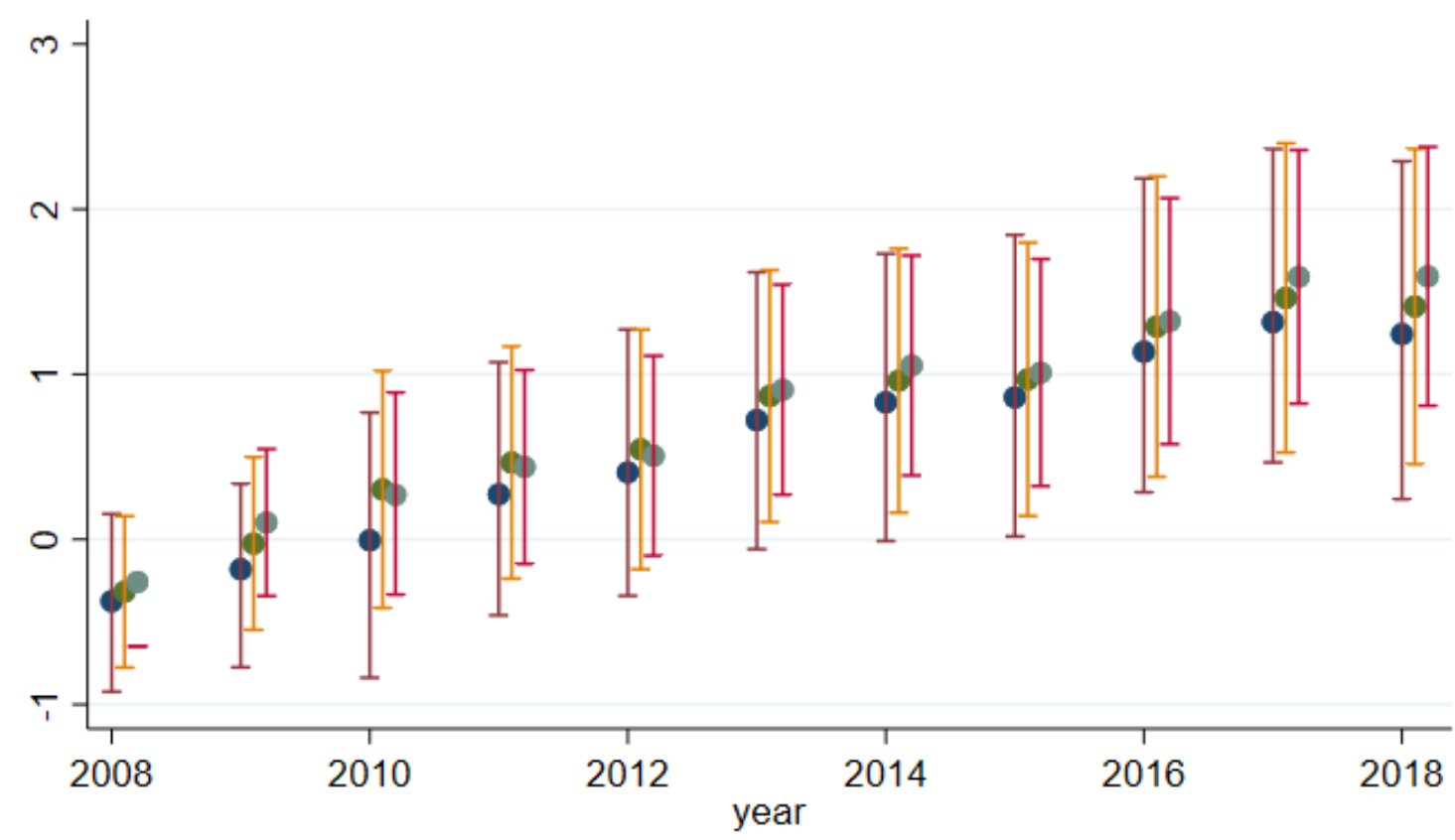

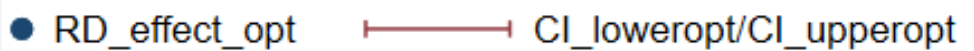

- RD_effect_20 $\longmapsto$ Cl_lower20/Cl_upper20

- RD_effect_30 $\longmapsto$ Cl_lower30/Cl_upper30

Note: This figure shows the robust bias-corrected and optimal-bandwidth point estimates in relation to other bandwidths (20 km and $30 \mathrm{~km}$ ). Standard errors are clustered using $25 \mathrm{~km}$ bins. 
Table 3.5 - RD estimator effect (\% of forest cover) excluding rural settlements

\begin{tabular}{|c|c|c|c|c|c|c|}
\hline \multirow{2}{*}{ Year } & \multirow{2}{*}{ Opt. Band } & \multirow{2}{*}{$\delta$} & \multicolumn{2}{|c|}{ Robust Inference } & & \multirow{2}{*}{ \# of obs. } \\
\hline & & & $\mathrm{Sd}$ & CI & & \\
\hline 2008 & 9.2 & -0.122 & 0.238 & -0.648 & 0.449 & 1210314222 \\
\hline 2009 & 11.1 & -0.205 & 0.231 & -0.696 & 0.361 & 1444517019 \\
\hline 2010 & 11.1 & -0.157 & 0.229 & -0.667 & 0.384 & 1475517306 \\
\hline 2011 & 8.9 & 0.419 & 0.345 & -0.228 & 1.316 & 1178913753 \\
\hline 2012 & 7.9 & $0.711^{* *}$ & 0.380 & 0.037 & 1.705 & 1061012394 \\
\hline 2013 & 8.5 & $1.060^{* * *}$ & 0.393 & 0.362 & 2.092 & 1082312672 \\
\hline 2014 & 9.0 & $1.077^{* * *}$ & 0.390 & 0.353 & 2.111 & 1178913753 \\
\hline 2015 & 9.3 & $0.942^{* *}$ & 0.409 & 0.194 & 2.009 & 1207114092 \\
\hline 2016 & 10.7 & $1.108^{* * *}$ & 0.435 & 0.320 & 2.252 & 1403416390 \\
\hline 2017 & 10.1 & $1.459^{* * *}$ & 0.461 & 0.599 & 2.660 & 1307615243 \\
\hline 2018 & 11.4 & $1.028^{* *}$ & 0.440 & 0.173 & 2.161 & 1456917089 \\
\hline
\end{tabular}

Note: This table shows our RD estimates (\% of forest cover) when excluding rural settlements, as these areas are eligible for other federal conservation programmes. We use linear regression with control variables. Standard errors are clustered using $25 \mathrm{~km}$ bins; total of 1,449,105 observations. Significance levels: ${ }^{*} 10 \%,{ }^{*} 5 \%,{ }^{* * *} 1 \%$.

Table 3.6 - List of Full Protection Conservation Units

\begin{tabular}{ll}
\hline Name & Year \\
\hline Estação Ecológica do Jari & 1982 \\
Reserva Biológica do Rio Trombetas & 1979 \\
Parque Nacional do Araguaia & 1959 \\
Parque Nacional da Amazônia & 1974 \\
Reserva Biológica Gurupi & 1988 \\
Reserva Biológica Uatumã & 1990 \\
PARNA Montanhas do Tumucumaque & 2002 \\
REBIO Nascentes da Serra do Cachimbo & 2005 \\
PARNA Juruena & 2006 \\
Estação Ecológica Alto Maués & 2014 \\
Parna Acari & 2016 \\
\hline
\end{tabular}

Note: This table presents the list of protected areas used in our placebo test. 
Figure 3.10 - Location of rural settlements

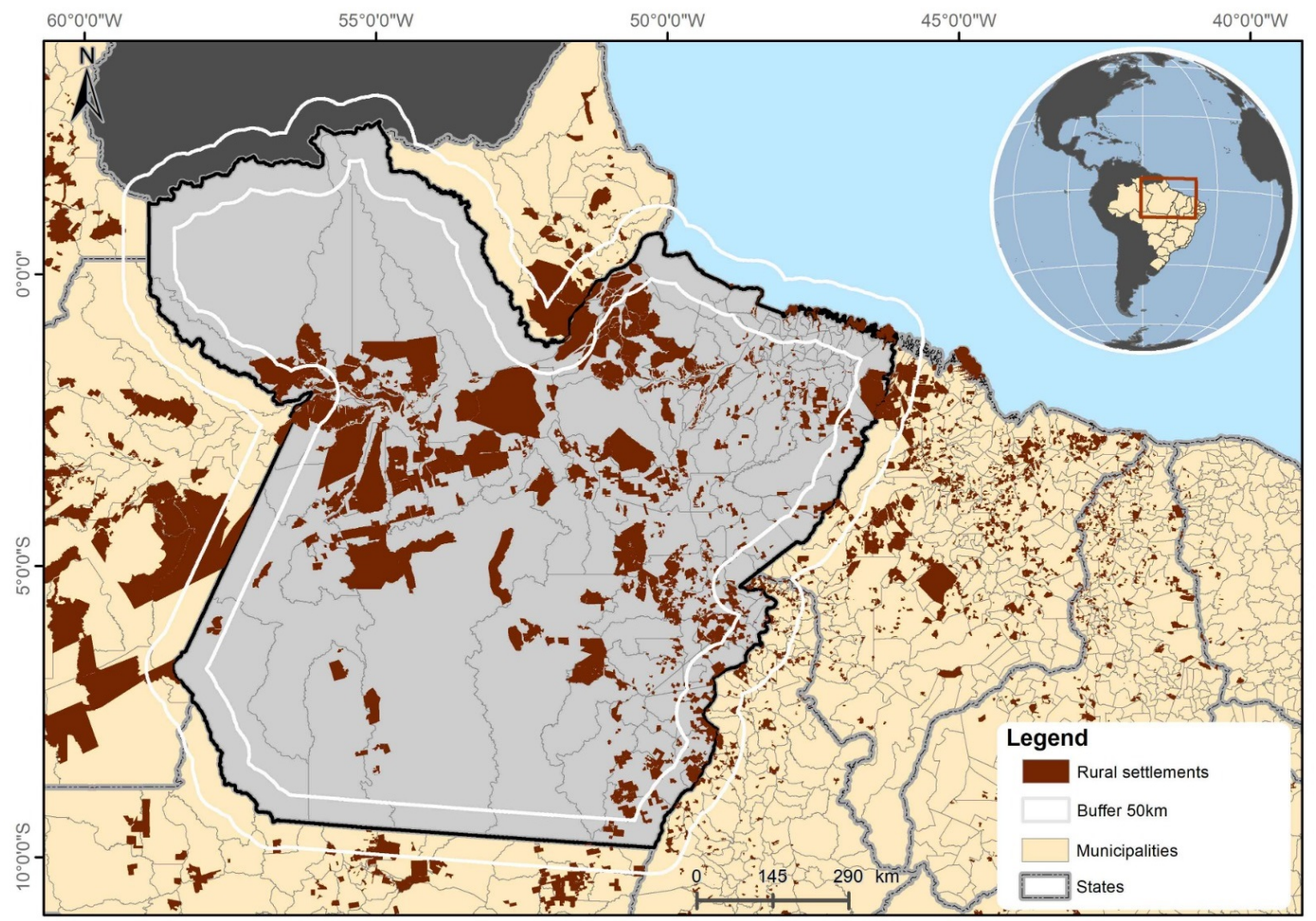

Note: This figure shows the location of rural settlements, areas eligible for other federal conservation programmes. It corresponds to a total area of $63,581 \mathrm{~km}^{2}$ (332,017 observations). 
Table 3.7 - Placebo outcomes - RD estimator effect (\% of forest cover) on Full Protection Units

\begin{tabular}{|c|c|c|c|c|c|c|c|}
\hline \multirow{3}{*}{$\begin{array}{l}\text { Year } \\
2008\end{array}$} & \multirow{3}{*}{$\begin{array}{c}\text { Opt. B. } \\
\text { (in Km) } \\
7.1\end{array}$} & \multirow{3}{*}{$\begin{array}{c}\text { RD Est. } \\
\text { (in \%) }\end{array}$} & \multicolumn{3}{|c|}{ Robust Inference } & \multirow{2}{*}{\multicolumn{2}{|c|}{ \# of obs. }} \\
\hline & & & \multirow{2}{*}{$\begin{array}{c}\mathrm{p} \text { value } \\
0.167\end{array}$} & \multicolumn{2}{|c|}{$\mathrm{CI}$} & & \\
\hline & & & & -0.005 & 0.031 & 4361 & 2970 \\
\hline 2009 & 5.2 & 0.010 & 0.744 & -0.018 & 0.025 & 3308 & 2522 \\
\hline 2010 & 4.9 & 0.010 & 0.944 & -0.021 & 0.023 & 2935 & 2410 \\
\hline 2011 & 5.3 & 0.030 & 0.302 & -0.017 & 0.053 & 3312 & 2529 \\
\hline 2012 & 6.4 & 0.030 & 0.230 & -0.018 & 0.074 & 3964 & 2753 \\
\hline 2013 & 6.5 & 0.010 & 0.503 & -0.032 & 0.064 & 4071 & 2856 \\
\hline 2014 & 6.6 & 0.020 & 0.421 & -0.029 & 0.070 & 4078 & 2856 \\
\hline 2015 & 6.6 & 0.020 & 0.555 & -0.034 & 0.064 & 4078 & 2856 \\
\hline 2016 & 6.7 & 0.010 & 0.825 & -0.047 & 0.060 & 4150 & 2857 \\
\hline 2017 & 7.0 & 0.000 & 0.811 & -0.071 & 0.056 & 4295 & 2964 \\
\hline 2018 & 7.8 & -0.040 & 0.459 & -0.105 & 0.047 & 4822 & 3185 \\
\hline
\end{tabular}

Note: This table shows the estimates for our placebo test, using forest cover data of grid cells located in protected areas as outcome variables. We use linear regression with control variables. Standard errors are clustered using $25 \mathrm{~km}$ bins; total of 474,507 observations. Significance levels: ${ }^{*} 10 \%, * * 5 \%, * * * 1 \%$. 
Table 3.8 - Treatment effect (\% of forest cover) accounting for unobservable heterogeneity

\begin{tabular}{|c|c|c|c|c|c|c|}
\hline \multirow{3}{*}{$\frac{\text { Year }}{t-10}$} & \multicolumn{3}{|c|}{ (1) } & \multicolumn{3}{|c|}{$(2)$} \\
\hline & \multirow{2}{*}{$\begin{array}{c}\delta \\
-3.123 \\
(1.331)\end{array}$} & \multicolumn{2}{|c|}{ CI } & \multirow{2}{*}{$\begin{array}{c}\delta \\
-2.858 \\
(1.248)\end{array}$} & \multicolumn{2}{|c|}{ CI } \\
\hline & & -5.732 & -0.514 & & -5.305 & -0.411 \\
\hline$t-9$ & $\begin{array}{l}-1.357 \\
(1.338)\end{array}$ & -3.979 & 1.266 & $\begin{array}{l}-1.109 \\
(1.254)\end{array}$ & -3.568 & 1.349 \\
\hline$t-8$ & $\begin{array}{c}-0.916 \\
(1.338)\end{array}$ & -3.537 & 1.706 & $\begin{array}{c}-0.674 \\
(1.254)\end{array}$ & -3.131 & 1.784 \\
\hline$t-7$ & $\begin{array}{l}-0.763 \\
(1.338)\end{array}$ & -3.386 & 1.859 & $\begin{array}{c}-0.535 \\
(1.254)\end{array}$ & -2.994 & 1.923 \\
\hline$t-6$ & $\begin{array}{c}-0.505 \\
(1.328)\end{array}$ & -3.108 & 2.098 & $\begin{array}{c}-0.283 \\
(1.245)\end{array}$ & -2.724 & 2.157 \\
\hline$t-5$ & $\begin{array}{c}-0.252 \\
(1.293)\end{array}$ & -2.786 & 2.282 & $\begin{array}{c}-0.063 \\
1.212\end{array}$ & -2.439 & 2.313 \\
\hline$t-4$ & $\begin{array}{c}-0.257 \\
(1.293)\end{array}$ & -2.791 & 2.277 & $\begin{array}{c}-0.098 \\
(1.212)\end{array}$ & -2.474 & 2.278 \\
\hline$t-3$ & $\begin{array}{l}-0.157 \\
(0.993)\end{array}$ & -0.574 & 1.022 & $\begin{array}{c}1.244 \\
(0.124)\end{array}$ & 1.001 & 1.487 \\
\hline$t-2$ & $\begin{array}{l}-0.103 \\
(0.879)\end{array}$ & -0.069 & 0.275 & $\begin{array}{l}-0.118 \\
(0.924)\end{array}$ & -0.063 & 0.299 \\
\hline$t-1$ & $\begin{array}{c}-0.016 \\
(0.080)\end{array}$ & -0.172 & 0.141 & $\begin{array}{l}-0.115 \\
(0.084)\end{array}$ & -0.280 & 0.051 \\
\hline$t+1$ & $\begin{array}{c}0.054 \\
(0.080)\end{array}$ & -0.103 & 0.210 & $\begin{array}{c}0.067 \\
(0.084)\end{array}$ & -0.098 & 0.232 \\
\hline$t+2$ & $\begin{array}{c}0.005 \\
(0.088)\end{array}$ & -0.192 & 0.148 & $\begin{array}{c}0.110 \\
(0.091)\end{array}$ & -0.069 & 0.289 \\
\hline$t+3$ & $\begin{array}{c}0.797 * * * \\
(0.114)\end{array}$ & 0.168 & 0.177 & $\begin{array}{c}0.199 * * \\
(0.093)\end{array}$ & 0.018 & 0.381 \\
\hline$t+4$ & $\begin{array}{c}0.177^{* *} \\
(0.088)\end{array}$ & 0.004 & 0.350 & $\begin{array}{c}0.337^{* * *} \\
(0.093)\end{array}$ & 0.156 & 0.519 \\
\hline$t+5$ & $\begin{array}{c}0.329 * * * \\
(0.088)\end{array}$ & 0.156 & 0.503 & $\begin{array}{c}0.471^{* * *} \\
(0.093)\end{array}$ & 0.289 & 0.653 \\
\hline$t+6$ & $\begin{array}{c}0.546^{* * *} \\
(0.089)\end{array}$ & 0.373 & 0.720 & $\begin{array}{c}0.662^{* * *} \\
(0.093)\end{array}$ & 0.481 & 0.845 \\
\hline$t+7$ & $\begin{array}{c}0.740^{* * *} \\
(0.089)\end{array}$ & 0.565 & 0.915 & $\begin{array}{c}0.881^{* * *} \\
(0.093)\end{array}$ & 0.699 & 1.065 \\
\hline$t+8$ & $\begin{array}{c}1.098^{* * *} \\
(0.108)\end{array}$ & 0.887 & 1.309 & $\begin{array}{c}1.504^{* * *} \\
(0.110)\end{array}$ & 1.289 & 1.721 \\
\hline Obs & & ,446,388 & & & 169,612 & \\
\hline Controls & & Yes & & & Yes & \\
\hline Municipality FE & & Yes & & & Yes & \\
\hline Year FE & & Yes & & & Yes & \\
\hline Priority Municipality & & Yes & & & No & \\
\hline Adj. $R^{2}$ & & 0.1025 & & & 0.109 & \\
\hline
\end{tabular}

Note: This table presents the the average treatment effect $(\delta, \%$ of forest cover) in individual years using a difference-in-differences (DID) estimator with leads and lags. Specification (1) excludes grid cells from rural settlements as they might be eligible for Bolsa Verde and (2) additionally excludes grid cells belonging to priority municipalities. $\delta$ estimates should be interpreted as the differences in forest cover rate with reference to year $t=0$. Significance levels: ${ }^{*} 10 \%, * * 5 \%, * * * 1 \%$. 


\section{B Validation tests}

\section{B.1 Predetermined controls}

To obtain internal validation and causal interpretation of our empirical results, certain conditions must be met. Factors that might influence deforestation should not present discontinuities - meaning a jump or drop in the levels - at the Pará border. Following Cattaneo et al. (2019), we plot each control variable - soil, slope, distance to roads, streams, urban agglomerations and IBAMA offices - inside their respective MSE-optimal bandwidth and also for the full sample (bandwidth of $50 \mathrm{~km}$ ), using a polynomial of order one and a triangular kernel function to weight the observations. As per our main specification, we also use clustered standard errors in $25 \mathrm{~km}$ bins. Table 3.9 presents the robust bias-corrected RD estimates, and the results suggest that these variables are evenly distributed around the Pará border. Validation checks are also conducted separately for all years.

Table 3.9 - Validation test - predetermined controls

\begin{tabular}{lcccccc}
\hline \multirow{2}{*}{ Variable } & & & \multicolumn{2}{c}{ Robust Inference } & \multirow{2}{*}{ \#pt. B. } \\
\cline { 4 - 5 } & & $\delta$ & $\mathrm{p}$ value & CI & \\
\hline Soil $(\log )$ & 5.4 & -0.007 & 0.969 & -.0336 .0323 & 893911984 \\
Slope & 6.6 & -0.010 & 0.210 & -.0292 .0064 & 1074314068 \\
Dist. streams & 3.9 & -19.95 & 0.131 & -34.38 & 4.45 & 62538814 \\
Dist. roads $(\log )$ & 10.4 & 0.039 & 0.415 & -.0706 .1711 & 1660321512 \\
Dist. commun. $(\log )$ & 5.6 & -0.009 & 0.503 & -.0999 .0490 & 907511063 \\
Dist. IBAMA $(\log )$ & 8.1 & 0.005 & 0.908 & -.0338 .0300 & 1321617128 \\
\hline
\end{tabular}

Note: This table presents the regression estimates of the Pará dummy, $\delta$, on geographic (soil type, slope and distance to streams) and structural controls (distance to roads, municipalities, and IBAMA offices), using linear polynomials. Column 'Opt.Band' refers to the average optimal and bias-correction bandwidth in kilometres. Column 'Robust Inference' presents the p value and the confidence intervals. Standard errors are clustered using $25 \mathrm{~km}$ bins. Units of observations are $1 \mathrm{~km}^{2}$ pixel within the $50 \mathrm{~km}$ from Pará's border, and number of observations are separated by left and right side of the state borders within the optimal bandwidth. Significance levels: *10\%, **5\%, ***1\%.

\section{B.2 Manipulation around the cutoff}

We analyse the density of the running variable to verify any possible manipulation or sorting around the Pará border, which should be the same on each side. As presented 
in Figure 3.11, no major differences in the distribution of the running variable.

We also follow Cattaneo et al. (2019), who constructed a manipulation tests based on density discontinuity (McCrary, 2008) using the results for the local polynomial distribution estimator. We do not find evidence of manipulation as we do not reject the null hypothesis of this test (no discontinuity of the density at the cutoff) ${ }^{3.38}$.

The current geographic limits of Pará are defined by rivers such as Rio Jari, Rio Nhamundá, Rio São Manuel, Rio Araguaia and Rio Gurupi, and the Atlantic Ocean. The exceptions are two straight lines: in the west, bordering Amazonas and Roraima states, and in the south, bordering Mato Grosso state. Historically, the occupation of Pará followed its rivers, especially the Amazon River, so the limits between current states of Pará and Amazonas were not completely unexplored when these were defined (Gadelha, 2002). However, the straight-line borders correspond to areas that were sparsely occupied areas in the late 19th century when they were defined. They can be understood as being more less arbitrary and not related to any previous natural or institutional border (Burgess et al., 2019).

By and large, the deforestation differences that we find are driven by substantial changes in forest cover, which are driven by conversion of forests to grasslands for animal grazing or conversion to croplands. These major land use changes require permanent factor reallocation from one side of the border to the other. Selective logging of valuable timber ${ }^{3.39}$, may indeed present cross-border mobility, in spite of being illicit. However, we do not think such sorting behaviour threatens our identification, as our measure of deforestation is not responsive to such minor changes.

\footnotetext{
${ }^{3.38} \mathrm{p}$ value of 0.61 , $\mathrm{t}$ stat of -0.50 .

${ }^{3.39}$ Practice where a single valuable tree, such as for example mahogany in the tropics, is harvested due to its relatively high market value.
} 
Figure 3.11 - Test for manipulation around the cutoff: density of the running variable

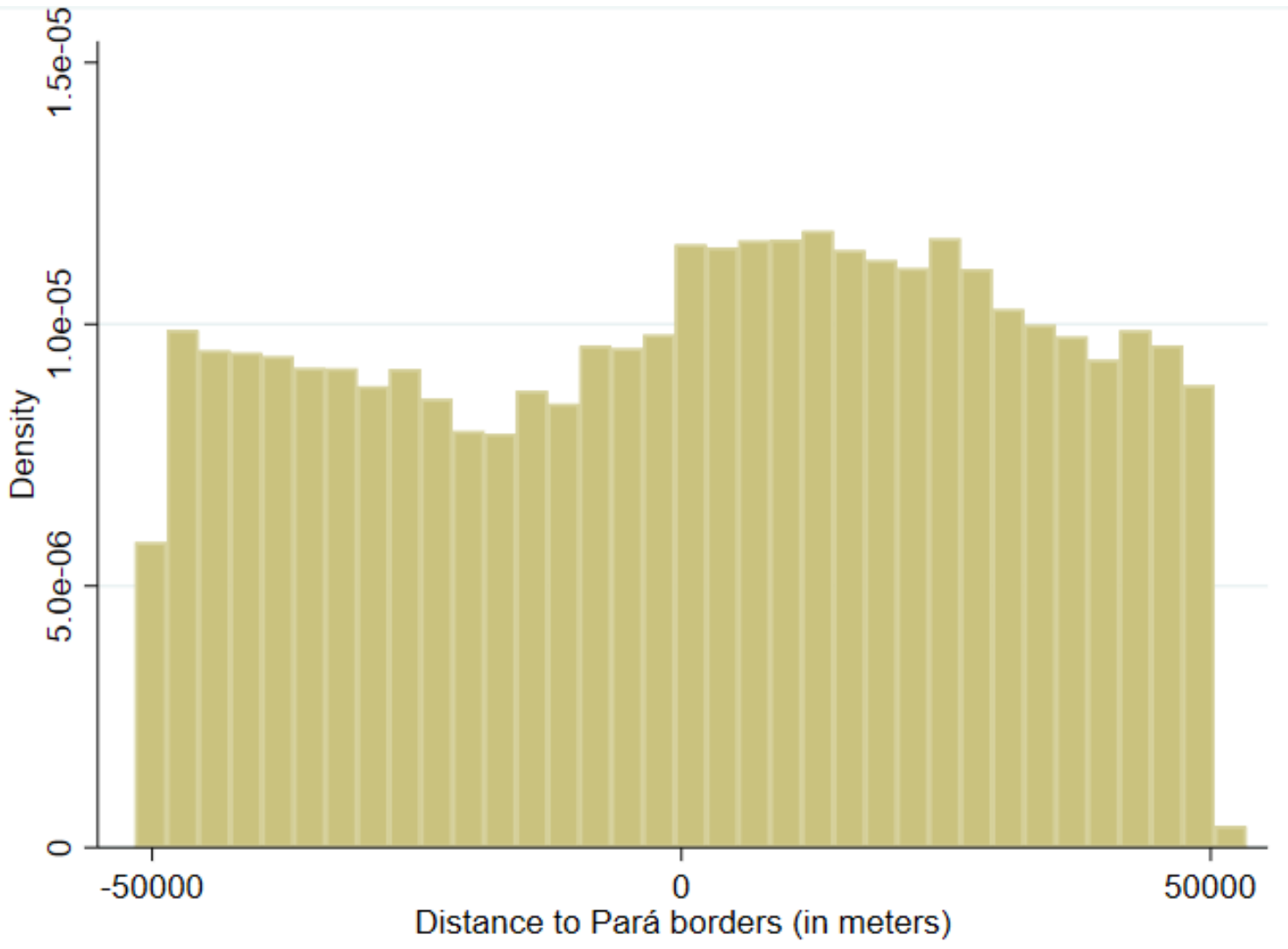

Note: This histogram presents the density of grid cells observed in 2-km spaced bins. Distance to Pará borders in meters. 



\section{REFERENCES}

ABRANCHES, S. The political economy of deforestation in brazil and payment-forperformance finance. Londres: Center for Global Development, 2014.

AIDY, J. E. The Political Economy of Carbon Pricing Policy Design. [S.1.]: Harvard Project on Climate Agreements, 2017.

ALMEIDA, C. A. d. et al. High spatial resolution land use and land cover mapping of the brazilian legal amazon in 2008 using landsat-5/tm and modis data. Acta Amazonica, SciELO Brasil, v. 46, n. 3, p. 291-302, 2016.

ANDERSON, L. O. et al. The effects of land use regulation on deforestation: evidence from the Brazilian Amazon. [S.1.], 2016.

ANDERSSON, K.; GIBSON, C. C. Decentralized governance and environmental change: local institutional moderation of deforestation in bolivia. Journal of Policy Analysis and Management, Wiley Online Library, v. 26, n. 1, p. 99-123, 2007.

ANP AGêNCIA NACIONAL DO PETRóLEO, G. N. e. B. Dados estatísticos mensais: vendas de combustiveis. 2020.

ASSUNÇÃO, J.; GANDOUR, C.; ROCHA, R. Deforestation slowdown in the brazilian amazon: prices or policies? Environment and Development Economics, Cambridge University Press, v. 20, n. 6, p. 697-722, 2015.

AZEVEDO, I. M. Consumer end-use energy efficiency and rebound effects. Annual Review of Environment and Resources, Annual Reviews, v. 39, p. 393-418, 2014.

BABIKER, M. H.; METCALF, G. E.; REILLY, J. Tax distortions and global climate policy. Journal of Environmental Economics and Management, Elsevier, v. 46, n. 2, p. 269-287, 2003.

BACCINI, A. et al. Tropical forests are a net carbon source based on aboveground measurements of gain and loss. Science, American Association for the Advancement of Science, v. 358, n. 6360, p. 230-234, 2017.

BALAND, J.-M. et al. Forests to the people: Decentralization and forest degradation in the indian himalayas. World Development, Elsevier, v. 38, n. 11, p. 1642-1656, 2010.

BANK, W. CO2 emissions (metric tons per capita). [S.l.]: The World Bank Group, 2014.

BARLOW, J. et al. Quantifying the biodiversity value of tropical primary, secondary, and plantation forests. Proceedings of the National Academy of Sciences, National Acad Sciences, v. 104, n. 47, p. 18555-18560, 2007. 
BASSO, L. Brazilian energy-related climate (in) action and the challenge of deep decarbonization. Revista Brasileira de Política Internacional, SciELO Brasil, v. 62, n. 2, 2019.

BAST, E. et al. Empty promises: G20 subsidies to oil, gas and coal production. Overseas Development Institute (ODI), 2015.

BECK, M. et al. Carbon tax and revenue recycling: Impacts on households in british columbia. Resource and Energy Economics, Elsevier, v. 41, p. 40-69, 2015.

BONILLA-MEJÍA, L.; HIGUERA-MENDIETA, I. Protected areas under weak institutions: Evidence from colombia. World Development, Elsevier, v. 122, p. 585-596, 2019 .

BOWEN, A. Carbon pricing: How best to use the revenue. [S.l.], 2015.

BOYCE, J. K. Distributional issues in climate policy: air quality co-benefits and carbon rent. Amherst, MA: University of Massachusetts, Political Economy Research Institute, Working Paper, n. 412, 2016.

BOYSEN, O. et al. A food demand system estimation for Uganda. [S.1.], 2012.

BRÄNNLUND, R.; GHALWASH, T.; NORDSTRÖM, J. Increased energy efficiency and the rebound effect: effects on consumption and emissions. Energy Economics, Elsevier, v. 29, n. 1, p. 1-17, 2007.

BRÄNNLUND, R.; NORDSTRÖM, J. Carbon tax simulations using a household demand model. European Economic Review, Elsevier, v. 48, n. 1, p. 211-233, 2004.

BRASIL. Pretendida Contribuição Nacionalmente Determinada (Indc) Para Consecução do Objetivo da Convenção-Quadro das Nações Unidas sobre Mudança do Clima. 2015. Available at: < http://www.itamaraty.gov.br/images/ed_desenvsust/BRASIL-iNDC-portugues. pdf $>$.

BRASIL, M. Terceiro Inventário Brasileiro de Emissões e Remoções Antrópicas de Gases de Efeito Estufa: Relatório de Referência-Emissões no Setor Uso da Terra, Mudança do Uso da Terra e Florestas. [S.l.]: Brasília, DF: MCTI, 2015.

BRASIL, S. Sistema de estimativas de emissões de gases de efeito estufa. Brasília: Observatório do Clima, 2020.

BRENNER, M.; RIDDLE, M.; BOYCE, J. K. A chinese sky trust? distributional impacts of carbon charges and revenue recycling in china. Energy Policy, Elsevier, v. 35, n. 3, p. 1771-1784, 2007.

BUREAU, B. Distributional effects of a carbon tax on car fuels in france. Energy Economics, Elsevier, v. 33, n. 1, p. 121-130, 2011.

BURGESS, R.; COSTA, F.; OLKEN, B. A. The Brazilian Amazon's Double Reversal of Fortune. [S.l.], 2019. 
CALLAN, T. et al. The distributional implications of a carbon tax in ireland. Energy Policy, Elsevier, v. 37, n. 2, p. 407-412, 2009.

CARATTINI, S.; CARVALHO, M.; FANKHAUSER, S. Overcoming public resistance to carbon taxes. Wiley Interdisciplinary Reviews: Climate Change, Wiley Online Library, v. 9, n. 5, p. e531, 2018.

CARON, J.; FAlLY, T. Per Capita Income, Consumption Patterns, and CO2 Emissions. [S.1.], 2018.

CATtAneO, M. D.; IDROBO, N.; TITIUNIK, R. A Practical Introduction to Regression Discontinuity Designs: Foundations. [S.l.]: Cambridge University Press, 2019.

CHITNIS, M.; SORRELL, S. Living up to expectations: Estimating direct and indirect rebound effects for uk households. Energy Economics, Elsevier, v. 52, p. S100-S116, 2015.

CHITNIS, M. et al. Who rebounds most? estimating direct and indirect rebound effects for different uk socioeconomic groups. Ecological Economics, Elsevier, v. 106, p. 12-32, 2014.

CISNEROS, E.; ZHOU, S. L.; BÖRNER, J. Naming and shaming for conservation: Evidence from the brazilian amazon. PloS One, Public Library of Science, v. 10, n. 9, 2015.

COADY, D. et al. How large are global energy subsidies? [S.l.], 2015.

COHEN, C.; LENZEN, M.; SCHAEFFER, R. Energy requirements of households in brazil. Energy Policy, Elsevier, v. 33, n. 4, p. 555-562, 2005.

CONLEY, T. G. Gmm estimation with cross sectional dependence. Journal of econometrics, Elsevier, v. 92, n. 1, p. 1-45, 1999.

COTTRELL, J.; FALCÃO, T. A climate of fairness: environmental taxation and tax justice in developing countries. [S.1.], 2018.

COX, T. L.; WOHLGENANT, M. K. Prices and quality effects in cross-sectional demand analysis. American Journal of Agricultural Economics, Oxford University Press, v. 68, n. 4, p. 908-919, 1986.

CRONIN, J. A.; FULLERTON, D.; SEXTON, S. Vertical and horizontal redistributions from a carbon tax and rebate. Journal of the Association of Environmental and Resource Economists, University of Chicago Press Chicago, IL, v. 6, n. S1, p. pp. 169-208, 2019.

CUARESMA, J. C.; HEGER, M. Deforestation and economic development: Evidence from national borders. Land Use Policy, Elsevier, v. 84, p. 347-353, 2019. 
DAHL, C. A. Measuring global gasoline and diesel price and income elasticities. Energy Policy, Elsevier, v. 41, p. 2-13, 2012.

DEATON, A. Price elasticities from survey data: extensions and indonesian results. Journal of Econometrics, Elsevier, v. 44, n. 3, p. 281-309, 1990.

DEATON, A.; MUELlBAUER, J. An almost ideal demand system. The American Economic Review, JSTOR, v. 70, n. 3, p. 312-326, 1980.

DEATON, A.; MUELLBAUER, J. Economics and consumer behavior. [S.l.]: Cambridge University Press, 1980.

DEVARAJAN, S. et al. Tax policy to reduce carbon emissions in a distorted economy: Illustrations from a south africa cge model. The BE Journal of Economic Analysis 8 Policy, De Gruyter, v. 11, n. 1, 2011.

DEY, C. et al. Household environmental pressure from consumption: an australian environmental atlas. In: . [S.l.]: Sydney University Press, 2007.

DORBAND, I. I. et al. Poverty and distributional effects of carbon pricing in low-and middle-income countries-a global comparative analysis. World Development, Elsevier, v. 115, p. 246-257, 2019.

DRUCKMAN, A. et al. Missing carbon reductions? exploring rebound and backfire effects in uk households. Energy Policy, Elsevier, v. 39, n. 6, p. 3572-3581, 2011.

DRUCKMAN, A. et al. Missing carbon reductions? exploring rebound and backfire effects in uk households. Energy Policy, Elsevier, v. 39, n. 6, p. 3572-3581, 2011.

DRUCKMAN, A.; JACKSON, T. The carbon footprint of uk households 1990-2004: a socio-economically disaggregated, quasi-multi-regional input-output model. Ecological economics, Elsevier, v. 68, n. 7, p. 2066-2077, 2009.

EDENHOFER, O. Climate change 2014: mitigation of climate change. [S.1.]: Cambridge University Press, 2015.

FAN, J. et al. Embedded carbon footprint of chinese urban households: structure and changes. Journal of Cleaner Production, Elsevier, v. 33, p. 50-59, 2012.

FENG, K. et al. Distributional effects of climate change taxation: the case of the UK. [S.l.]: ACS Publications, 2010.

FENG, K. et al. Managing the distributional effects of energy taxes and subsidy removal in latin america and the caribbean. Applied Energy, Elsevier, v. 225, p. 424-436, 2018.

FLUES, F.; THOMAS, A. The distributional effects of energy taxes. OECD Publishing, 2015 . 
FREITAS, L. F. da S. et al. The distributional effects of emissions taxation in brazil and their implications for climate policy. Energy Economics, Elsevier, v. 59, p. 37-44, 2016.

FREMSTAD, A.; PAUL, M. The impact of a carbon tax on inequality. Ecological Economics, Elsevier, v. 163, p. 88-97, 2019.

FRONDEL, M.; VANCE, C. Re-identifying the rebound: what about asymmetry? The Energy Journal, JSTOR, p. 43-54, 2013.

FULLERTON, D. Six distributional effects of environmental policy. Risk Analysis: An International Journal, Wiley Online Library, v. 31, n. 6, p. 923-929, 2011.

FULLERTON, D.; METCALF, G. E. Environmental taxes and the double-dividend hypothesis: did you really expect something for nothing? [S.l.], 1997.

FULLERTON, D.; MUEHLEGGER, E. Who bears the economic burdens of environmental regulations? Review of Environmental Economics and Policy, Oxford University Press, v. 13, n. 1, p. 62-82, 2019.

GADELHA, R. M. A. F. Conquista e ocupação da amazônia: a fronteira norte do brasil. Estudos Avançados, SciELO Brasil, v. 16, n. 45, p. 63-80, 2002.

GATELY, D.; HUNTINGTON, H. G. The asymmetric effects of changes in price and income on energy and oil demand. The Energy Journal, JSTOR, p. 19-55, 2002.

GERTLER, P. J. et al. The demand for energy-using assets among the world's rising middle classes. American Economic Review, v. 106, n. 6, p. 1366-1401, 2016.

GHALWASH, T. Energy taxes as a signaling device: An empirical analysis of consumer preferences. Energy Policy, Elsevier, v. 35, n. 1, p. 29-38, 2007.

GOLLEY, J.; MENG, X. Income inequality and carbon dioxide emissions: The case of chinese urban households. Energy Economics, Elsevier, v. 34, n. 6, p. 1864-1872, 2012.

GOULDER, L. H. Environmental taxation and the double dividend: a reader's guide. International tax and public finance, Springer, v. 2, n. 2, p. 157-183, 1995.

GRAINGER, C. A.; KOLSTAD, C. D. Who pays a price on carbon? Environmental and Resource Economics, Springer, v. 46, n. 3, p. 359-376, 2010.

GRANADO, F. J. A. del; COADY, D.; GILLINGHAM, R. The unequal benefits of fuel subsidies: A review of evidence for developing countries. World Development, Elsevier, v. 40, n. 11, p. 2234-2248, 2012.

GROTTERA, C.; JR, A. O. P.; ROVERE, E. L. L. Impacts of carbon pricing on income inequality in brazil. Climate and Development, Taylor \& Francis, v. 9, n. 1, p. 80-93, 2017. 
GUILHOTO, J. et al. Estimação da matriz insumo-produto utilizando dados preliminares das contas nacionais: Aplicação e análise de indicadores econômicos para o brasil em 2005 (using data from the system of national accounts to estimate input-output matrices: An application using brazilian data for 2005). 2010.

HANSEN, M. C. et al. High-resolution global maps of 21st-century forest cover change. Science, American Association for the Advancement of Science, v. 342, n. 6160, p. 850-853, 2013.

HARBERGER, A. C. Three basic postulates for applied welfare economics: an interpretive essay. Journal of Economic Literature, JSTOR, v. 9, n. 3, p. 785-797, 1971.

HASSETT, K. A.; MATHUR, A.; METCALF, G. E. The incidence of a US carbon tax: A lifetime and regional analysis. [S.l.], 2007.

HEIEN, D.; WESSEILS, C. R. Demand systems estimation with microdata: a censored regression approach. Journal of Business 85 Economic Statistics, Taylor \& Francis Group, v. 8, n. 3, p. 365-371, 1990.

HOFFMANN, R. Desigualdade da renda e das despesas per capita no brasil, em 2002-2003 e 2008-2009, e avaliação do grau de progressividade ou regressividade de parcelas da renda familiar. Economia e sociedade, SciELO Brasil, v. 19, n. 3, p. 647-661, 2010.

IBGE, P. I. B. d. m. .-. Sidra: sistema IBGE de recuperação automática. 2010. Available at: <http://www.sidra.ibge.gov.br/bda/pesquisas/PIBMun/default.asp>.

IMBENS, G.; KALYANARAMAN, K. Optimal bandwidth choice for the regression discontinuity estimator. The Review of economic studies, Oxford University Press, v. 79, n. 3, p. 933-959, 2012.

IMF. Fiscal Policies for Paris Climate Strategies-from Principle to Practice. International Monetary Fund, 2019. (Policy Paper). Fiscal Affairs Department and IMF e-Library - York University. Available at: < https://books.google.it/books?id= ezFKzQEACAAJ>.

INPE, I. N. d. P. E. Monitoramento da floresta Amazônica Brasileira por satélite. 2013. Available at: <http://terrabrasilis.dpi.inpe.br/> .

INPE, I. N. d. P. E. Projeto de Monitoramento do Desmatamento na Amazônia Brasileira por Satélie (PRODES). 2019. Available at: <http://terrabrasilis.dpi.inpe.br/downloads/>.

IPCC, I. P. o. C. C. The physical science basis. contribution of working group i to the fourth assessment report of the ipcc. Cambridge University Press, Cambridge, United Kingdom and New York, NY, USA, v. 996, p. 2007, 2007. 
JACOBSON, M. Z. Effects of ethanol (e85) versus gasoline vehicles on cancer and mortality in the united states. Environmental Science \& Technology, ACS Publications, v. 41, n. 11, p. 4150-4157, 2007.

KAY, J. A. The deadweight loss from a tax system. Journal of Public Economics, Elsevier, v. 13, n. 1, p. 111-119, 1980.

KERKHOF, A. C. et al. Taxation of multiple greenhouse gases and the effects on income distribution: A case study of the netherlands. Ecological Economics, Elsevier, v. 67, n. 2, p. 318-326, 2008.

KERKHOF, A. C.; NONHEBEL, S.; MOLL, H. C. Relating the environmental impact of consumption to household expenditures: an input-output analysis. Ecological Economics, Elsevier, v. 68, n. 4, p. 1160-1170, 2009.

LABANDEIRA, X.; LABEAGA, J. M.; LÓPEZ-OTERO, X. A meta-analysis on the price elasticity of energy demand. Energy Policy, Elsevier, v. 102, p. 549-568, 2017.

LABANDEIRA, X.; LABEAGA, J. M.; RODRÍGUEZ, M. A residential energy demand system for spain. The Energy Journal, JSTOR, p. 87-111, 2006.

LAZARIDIS, P. Household meat demand in greece: A demand systems approach using microdata. Agribusiness, Wiley Online Library, v. 19, n. 1, p. 43-59, 2003.

LECOCQ, S.; ROBIN, J.-M. Estimating almost-ideal demand systems with endogenous regressors. The Stata Journal, SAGE Publications Sage CA: Los Angeles, CA, v. 15, n. 2 , p. 554-573, 2015.

LEVINSON, A.; O’BRIEN, J. Environmental Engel Curves. [S.1.], 2015.

LOZADA, A.; STERNER, T. The income distribution effects of fuel taxation in mexico. In: Fuel Taxes and the Poor. [S.l.]: RFF Press, 2012. p. 139-147.

L'ROE, J. et al. Mapping properties to monitor forests: Landholder response to a large environmental registration program in the brazilian amazon. Land Use Policy, Elsevier, v. 57, p. 193-203, 2016.

MAGALHÃES, A. S.; DOMINGUES, E. P. et al. Economia de baixo carbono no Brasil: alternativas de políticas e custos de redução de emissões de gases de efeito estufa. [S.I.], 2013.

MALCOLM, S. A.; AILlERY, M. P.; WEINBERG, M. Ethanol and a changing agricultural landscape. [S.l.], 2009.

MATHUR, A.; MORRIS, A. C. Distributional effects of a carbon tax in broader us fiscal reform. Energy Policy, Elsevier, v. 66, p. 326-334, 2014.

MCCRARY, J. Manipulation of the running variable in the regression discontinuity design: A density test. Journal of econometrics, Elsevier, v. 142, n. 2, p. 698-714, 2008. 
METCALF, G. E.; WEISBACH, D. The design of a carbon tax. Harv. Envtl. L. Rev., HeinOnline, v. 33, p. 499, 2009.

MINX, J. C. et al. Input-output analysis and carbon footprinting: an overview of applications. Economic Systems Research, Taylor \& Francis, v. 21, n. 3, p. 187-216, 2009.

MITEVA, D. A.; PATTANAYAK, S. K.; FERRARO, P. J. Evaluation of biodiversity policy instruments: what works and what doesn't? Oxford Review of Economic Policy, Oxford University Press UK, v. 28, n. 1, p. 69-92, 2012.

MOHRING, H. Alternative welfare gain and loss measures. Economic Inquiry, Wiley Online Library, v. 9, n. 4, p. 349-368, 1971.

MONTOYA, M. A.; LOPES, R. L.; GUILHOTO, J. J. M. Desagregação setorial do balanço energético nacional a partir dos dados da matriz insumo-produto: uma avaliação metodológica. Economia aplicada, SciELO Brasil, v. 18, n. 3, p. 379-419, 2014 .

MORRIS, D.; STERNER, T. Defying conventional wisdom: Distributional impacts of fuel taxes. In: Mistra Indigo Policy Paper 3. [S.1.]: IVL Swedish Environmental Research Institute, 2013.

NEVES, E.; COSTA, M. S.; WHATELY, M. Municipalities and policies against deforestation in the brazilian amazon. Novos estudos CEBRAP, SciELO Brasil, v. 35, n. 3, p. 67-83, 2016.

NIJDAM, D. S. et al. Environmental load from dutch private consumption: how much damage takes place abroad? Journal of Industrial Ecology, Wiley Online Library, v. 9, n. 1-2, p. 147-168, 2005.

NIKODINOSKA, D.; SCHRÖDER, C. On the emissions-inequality and emissionswelfare trade-offs in energy taxation: Evidence on the german car fuels tax. Resource and Energy Economics, Elsevier, v. 44, p. 206-233, 2016.

NOBRE, C. A. et al. Land-use and climate change risks in the amazon and the need of a novel sustainable development paradigm. Proceedings of the National Academy of Sciences, National Acad Sciences, v. 113, n. 39, p. 10759-10768, 2016.

NORDHAUS, W. D. Optimal greenhouse-gas reductions and tax policy in the"dice"model. The American Economic Review, JSTOR, v. 83, n. 2, p. 313-317, 1993.

NUAIMY-BARKER, R. G20 subsidies to oil, gas and coal production: Brazil. [S.l.], 2015.

OECD, O. f. E. C.-o.; DEVELOPMENT. Effective Carbon Rates 2018. [S.l.: s.n.], 2018. 
OHLENDORF, N. et al. Distributional impacts of climate mitigation policies-a meta-analysis. DIW Berlin Discussion Paper No. 1776, 2018.

OLIVEIRA, A. D.; LAAN, T. Lessons learned from Brazil's experience with fossil-fuel subsidies and their reform. [S.l.]: International Institute for Sustainable Development, Geneva, 2010.

PARRY, I.; VEUNG, C.; HEINE, D. How much carbon pricing is in countries' own interests? the critical role of co-benefits. Climate Change Economics, World Scientific, v. 6, n. $04,2015$.

PEARCE, D. The role of carbon taxes in adjusting to global warming. The economic journal, JSTOR, v. 101, n. 407, p. 938-948, 1991.

PEREDA, P. C. et al. Neutral carbon tax and environmental targets in brazil. Economic Systems Research, Taylor \& Francis, v. 31, n. 1, p. 70-91, 2019.

PEROBELLI, F. S.; FARIA, W. R.; VALE, V. de A. The increase in brazilian household income and its impact on co2 emissions: Evidence for 2003 and 2009 from input-output tables. Energy Economics, Elsevier, v. 52, p. 228-239, 2015.

PINDYCK, R. S. Climate change policy: what do the models tell us? Journal of Economic Literature, v. 51, n. 3, p. 860-72, 2013.

PINDYCK, R. S. The social cost of carbon revisited. Journal of Environmental Economics and Management, Elsevier, v. 94, p. 140-160, 2019.

PIZER, W. A.; SEXTON, S. Distributional impacts of energy taxes. [S.l.], 2017.

POI, B. P. et al. Easy demand-system estimation with quaids. Stata Journal, v. 12, n. 3 , p. 433, 2012.

POLLAK, R. A.; WALES, T. J. Demographic variables in demand analysis. Econometrica: Journal of the Econometric Society, JSTOR, p. 1533-1551, 1981.

POTERBA, J. M. Is the gasoline tax regressive? Tax policy and the economy, National Bureau of Economic Research and The MIT Press, v. 5, p. 145-164, 1991.

RAMSTEIN, C. et al. State and Trends of Carbon Pricing 2019. Washington, DC: The World Bank, 2019. Available at: < https://openknowledge.worldbank.org/handle/10986/31755>.

RASMUSSEN, L. V. et al. Understanding smallholders' intended deforestation behavior in the brazilian cerrado following environmental registry. Environmental Research Letters, IOP Publishing, v. 12, n. 9, 2017.

RAUSCH, S.; METCALF, G. E.; REILLY, J. M. Distributional impacts of carbon pricing: A general equilibrium approach with micro-data for households. Energy economics, Elsevier, v. 33, p. S20-S33, 2011. 
RAVALLION, M. Poverty comparisons: a guide to concepts and methods. [S.1.]: The World Bank, 1992.

REAÑOS, M. A. T.; WÖLFING, N. M. Household energy prices and inequality: Evidence from german microdata based on the easi demand system. Energy Economics, Elsevier, v. 70, p. 84-97, 2018.

RENNER, S. Poverty and distributional effects of a carbon tax in mexico. Energy Policy, Elsevier, v. 112, p. 98-110, 2018.

RENNER, S.; LAY, J.; GREVE, H. Household welfare and co2 emission impacts of energy and carbon taxes in mexico. Energy Economics, Elsevier, v. 72, p. 222-235, 2018.

RENNER, S.; LAY, J.; SCHLEICHER, M. The effects of energy price changes: Heterogeneous Welfare impacts, energy poverty, and CO2 emissions in Indonesia. [S.l.], 2017.

ROVERE, E. L. L.; SIMÕES, A. F. Climate change implications of the brazilian energy outlook. Terrae Campinas, v. 3, p. 4-15, 2008.

SAJEEWANI, D.; SIRIWARDANA, M.; MCNEILL, J. Household distributional and revenue recycling effects of the carbon price in australia. Climate Change Economics, World Scientific, v. 6, n. 03, p. 1550012, 2015.

SANTOS, P. F. A. et al. Os impactos do programa municípios verdes (pmv) no controle do desmatamento da amazônia: uma análise usando propensity score matching. Economia-Ensaios, v. 30, n. 2, 2016.

SCHMITZ, H.; MADLENER, R. Direct and Indirect Rebound Effects in German Households: A Linearized Almost Ideal Demand System Approach. [S.l.], 2017.

SEEG. Sistema de Estimativas de Emissões de Gases de Efeito Estufa. 2019.

SHONKWILER, J. S.; YEN, S. T. Two-step estimation of a censored system of equations. American Journal of Agricultural Economics, Oxford University Press, v. 81, n. 4, p. 972-982, 1999.

SICAR, S. N. d. C. A. R. Cadastro Ambiental Rural. 2020.

STERNER, T. Fuel taxes and the poor: the distributional effects of gasoline taxation and their implications for climate policy. [S.l.]: Routledge, 2012.

STIGLITZ, J. E. et al. Report of the high-level commission on carbon prices. [S.l.], 2017.

THOMAS, B. A.; AZEVEDO, I. L. Estimating direct and indirect rebound effects for us households with input-output analysis part 1: Theoretical framework. Ecological Economics, Elsevier, v. 86, p. 199-210, 2013. 
THOMAS, V.; CHINDARKAR, N. et al. Economic Evaluation of Sustainable Development. [S.l.]: Springer, 2019.

TIEZZI, S. The welfare effects and the distributive impact of carbon taxation on italian households. Energy Policy, Elsevier, v. 33, n. 12, p. 1597-1612, 2005.

TIMILSINA, G. R. Where is the carbon tax after thirty years of research? [S.l.], 2018.

VERÍSSIMO, A.; JR., C. S. Detalhamento do macrozoneamento ecológico económico do estado do pará: áreas para produção florestal manejada: relatório preliminar para discussão. Belém: Secretaria Especial de Estado de Produção, 2006.

VIANA, J. P. Dois anos de Bolsa Verde: Seria a meta alcançável? [S.1.], 2014.

WANG, Q. et al. Distributional effects of carbon taxation. Applied Energy, Elsevier, v. 184, p. 1123-1131, 2016.

WHATELY, M.; CAMPANILI, M. Programa Municípios Verdes: lições aprendidas e desafios para 2013/2014. [S.1.]: Programa Municípios Verdes, Governo do Pará, 2013.

WIER, M. et al. Are co2 taxes regressive? evidence from the danish experience. Ecological economics, Elsevier, v. 52, n. 2, p. 239-251, 2005.

WILLIAMS, R. C. et al. The initial incidence of a carbon tax across income groups. Resources for the future discussion paper, n. 14-24, 2014.

WOLOSIN, M.; HARRIS, N. Tropical forests and climate change: The latest science. World Resources Institute. Washington DC, 2018.

YEN, S. T.; KAN, K.; SU, S.-J. Household demand for fats and oils: two-step estimation of a censored demand system. Applied Economics, Taylor \& Francis, v. 34, n. 14, p. 1799-1806, 2002.

ZARIN, D. J. et al. Can carbon emissions from tropical deforestation drop by $50 \%$ in 5 years? Global change biology, Wiley Online Library, v. 22, n. 4, p. 1336-1347, 2016. 